\title{
ipen
}

AUTARQUIA ASSOCIADA À UNIVERSIDADE DE SÃO PAULO

APLICAÇÃO DA RADIAÇÃO GAMA NA DETERMINAÇÃO DE PARÂMETROS FÍSICOS EM MADEIRAS

Gilberto Carvalho

Tese apresentada como parte dos requisitos para obtenção do Grau de Doutor em Ciências na Área de Tecnologia Nuclear - Aplicações

Orientador:

Prof. Dr. Leonardo Gondim de Andrade e Silva 
INSTITUTO DE PESQUISAS ENERGÉTICAS E NUCLEARES

Autarquia associada à Universidade de São Paulo

\section{APLICAÇÃO DA RADIAÇÃO GAMA NA DETERMINAÇÃO DE PARÂMETROS FÍSICOS EM MADEIRAS}

Gilberto Carvalho

Tese apresentada como parte dos requisitos para obtenção do Grau de Doutor em Ciências na Área de Tecnologia Nuclear - Aplicações

Orientador:

Prof. Dr. Leonardo Gondim de Andrade e Silva

Versão Corrigida

Versão Original disponível no IPEN

São Paulo

2013 
Aos meus pais, Manoel e Cacilda (muitas saudades) e em especial à minha esposa, Zuleika, gostaria de dedicar este trabalho, pela sua paciência e compreensão e incentivo, tornando a execução deste projeto menos difícil. 


\section{AGRADECIMENTOS}

Agradeço ao meu orientador, Dr. Leonardo Gondim de Andrade e Silva, pelo tempo e confiança dedicados à realização deste trabalho.

Agradeço ao Dr. Wilson Aparecido Parejo Calvo, ex-gerente do Centro de Tecnologia das Radiações, pelo apoio logístico e a todos aqueles que direta ou indiretamente colaboraram para a consecução deste trabalho, em especial aos colegas Nelson Minoru Omi e Idacir Mantovani, sem os quais este trabalho não teria sido realizado a contento.

Agradeço ao Instituto de Pesquisas Energéticas e Nucleares pela oportunidade de realização desta tese. 


\title{
APLICAÇÃO DA RADIAÇÃO GAMA NA DETERMINAÇÃO DE PARÂMETROS FÍSICOS EM MADEIRAS
}

\author{
Gilberto Carvalho
}

\begin{abstract}
RESUMO
Por sua disponibilidade e características diferenciadas, a madeira foi um dos primeiros materiais a ser usado pelos seres humanos, com uma grande multiplicidade de usos, diretos e indiretos. Ainda hoje é uma importante fonte de energia doméstica e industrial, além de ser usada como matéria prima na fabricação de papel e celulose, nas indústrias químicas, moveleira, naval, de artigos esportivos, brinquedos e instrumentos musicais, bem como na construção civil e na distribuição de energia elétrica. A madeira tem sido bastante estudada, sendo do conhecimento dos pesquisadores da área, a influência de vários fatores no desenvolvimento das árvores e por consequência, nas madeiras, como temperatura, latitude, longitude, altitude, insolação, solo e índice pluviométrico, razões pelas quais, quando se trata de madeira, se fala sempre em propriedades médias. A densidade é na opinião da grande maioria dos pesquisadores, a propriedade mais importante da madeira, por manter estreitas relações com propriedades físicas e mecânicas. Há três tipos de densidades, básica, aparente e a verde. Destas, usou-se a densidade aparente, a $12 \%$ de umidade e próxima da umidade de equilíbrio com o meio ambiente e a densidade a verde, na simulação no laboratório. Neste trabalho foram utilizadas madeiras de densidades variáveis, de sete espécies diferentes, a saber: freijó, peroba-mica, jequitibá, muiracatiara, cumaru, ipê e sucupira. Para a determinação das densidades pelo método não convencional, um dos objetivos deste trabalho, foi usar os radioisótopos: ${ }^{241} \mathrm{Am},{ }^{133} \mathrm{Ba}$, ${ }^{192} \mathrm{Ir},{ }^{137} \mathrm{Cs}$ e ${ }^{60} \mathrm{Co}$, um detetor de cintilação de NaI e um espectrômetro multicanal, desenvolvendo-se uma técnica alternativa, rápida e precisa, fato evidenciado pelos resultados obtidos. Os parâmetros nucleares obtidos, como meias espessuras e coeficientes de absorção linear, proporcionaram a escolha do radioisótopo, ${ }^{137} \mathrm{Cs}$, em relação à energia, atividade, espessuras ótimas de ensaio, resolução e proteção radiológica, para simulação em laboratório da integridade física de postes de madeira e árvores vivas, constituindo os parâmetros nucleares e as simulações em laboratório, os outros importantes objetivos do trabalho.
\end{abstract}




\title{
APPLICATION OF GAMMA RADIATION IN THE DETERMINATION OF PHYSICAL PARAMETERS IN WOODS
}

\author{
ABSTRACT \\ Gilberto Carvalho
}

Due to availability and differentiated features, wood was one of first materials to be used by humans, with a wide variety of applications. Today it is still an important source of domestic and industrial energy, besides to be used as raw material in manufacture of pulp and cellulose, in chemical industry, furniture, naval, sporting goods, toys and musical instruments as well as in construction and distribution of electric energy. Wood has been studied intensively and researchers in the area are aware of the influence of various factors in the development of trees and as consequence, in wood, such as: temperature, latitude, longitude, altitude, sunlight, soil and rainfall, reasons for which when it refers to wood, always it is average properties. The density it is in the opinion of majority of researchers, the most important property of wood, maintaining a close relationship with mechanical and physics properties of wood. There are three types of densities; basic, apparent and green and among these we used the apparent density to $12 \%$ of moisture content and green, density of living trees. In this work it was used woods of various densities, of seven different species of trees, namely: "freijó", "peroba-mica“, “jequitibá”, “muiracatiara", "cumaru", "ipê" and "sucupira". For the determination of densities, one of the goals of this work, was to use the radioisotopes: ${ }^{241} \mathrm{Am},{ }^{133} \mathrm{Ba},{ }^{192} \mathrm{Ir},{ }^{137} \mathrm{Cs}$ and ${ }^{60} \mathrm{Co}$, a NaI scintillation detector and a multichannel spectrometer, developing a non-conventional method, fast and accurate, evidenced by results. The nuclear parameters obtained such as, half value layers and linear attenuation coefficients provided the choice of the best radioisotope, ${ }^{137} \mathrm{Cs}$, for inspection of electric wooden poles and living trees in the laboratory simulations, are others important goals of this work. 


\section{SUMÁRIO}

1 INTRODUÇÃO ...............................................................................................................1

1.1 Importância da madeira ...................................................................................1

1.1.1 Histórico ...........................................................................................................................................1

1.1.2 Ecológico ........................................................................................................................................1

1.1.3 Econômico...............................................................................................................................2

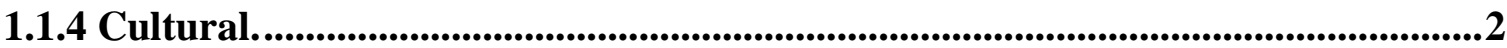

1.2 Árvores de interesse .............................................................................................3

1.2.1 Anatomia e fisiologia das árvores......................................................................................4

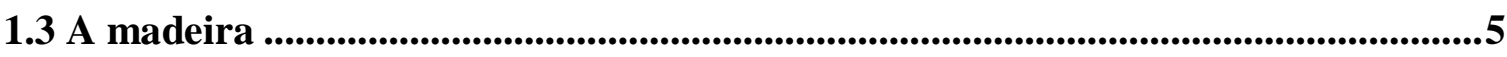

1.3.1 Anatomia e fisiologia e da madeira .....................................................................................5

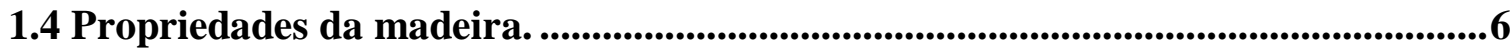

1.4.1 Propriedades mecânicas. ...........................................................................................6

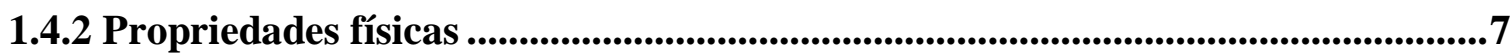

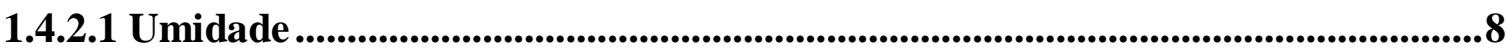

1.4.2.1.1 Teor de umidade .......................................................................................9

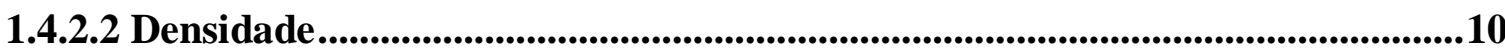

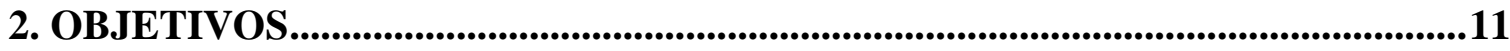

3. ORIGINALIDADE E CONTRIBUIÇÃO DO TRABALHO ...............................12

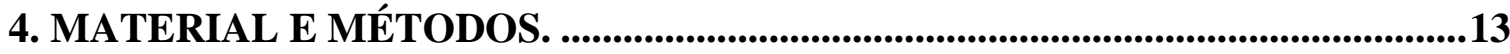

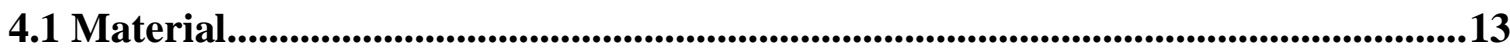

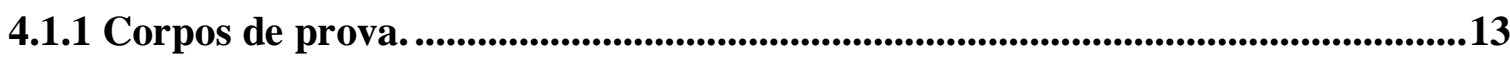

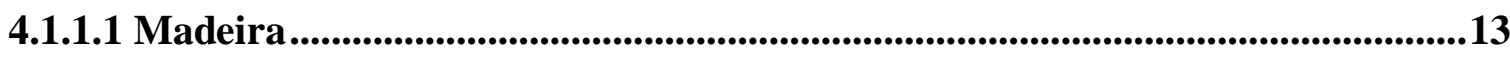

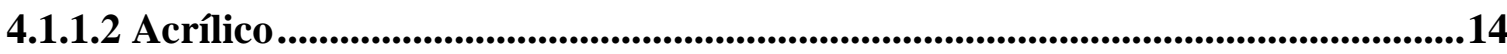

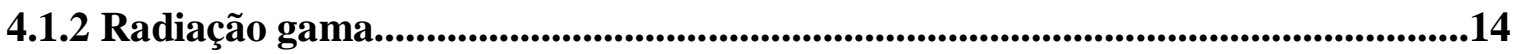

4.1.2.1 Interação da radiação gama com a matéria.................................................................14

4.1.2.2 Fontes radioativas........................................................................................15

4.1.2.2.1 Produção das fontes radioativas ..................................................................15

4.1.2.2.2 Características das fontes radioativas............................................................ 16

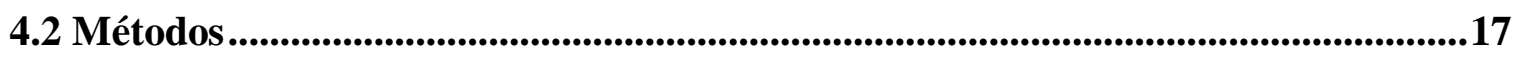

4.2.1 Determinação da umidade ...............................................................................................17

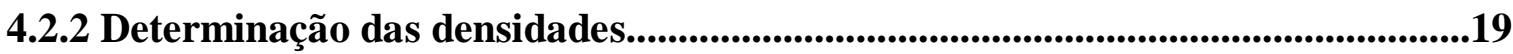


4.2.3 Determinação dos coeficientes de absorção linear e densidades.........................20

5 RESULTADOS E DISCUSSÃO ........................................................................................25

5.1 Determinação do teor de umidade em forno. ...................................................... 25

5.2 Determinação das densidades pelo método convencional .........................................25

5.3 Determinações das densidades e coeficientes de absorção linear usando radiação

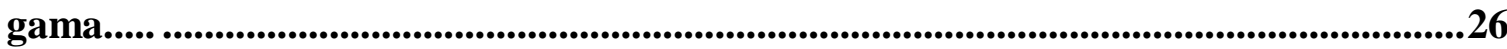

5.4 Determinação das meias espessuras ................................................................31

5.5 Simulação em laboratório de teste de integridade de postes de eucalipto com a

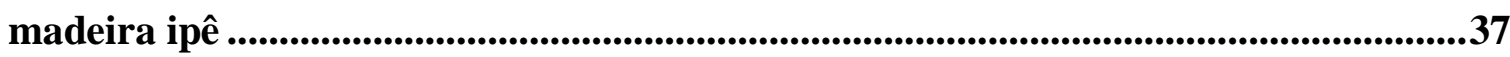

5.6 Simulação em laboratório de teste de integridade de árvores vivas com a madeira

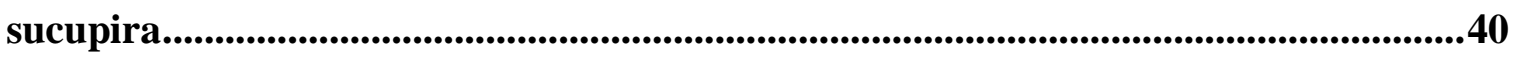

6 CONCLUSÕES ................................................................................................... 43

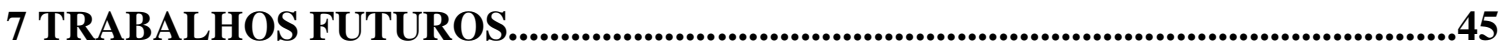

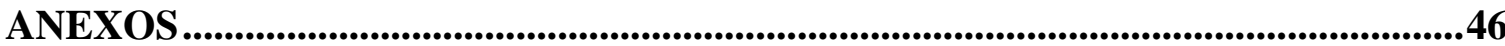

ANEXO I Árvores e madeiras de interesse ......................................................................... 46

ANEXO II Fontes radioisotópicas usadas .....................................................................55

ANEXO III Glossário de árvores e madeira .........................................................................58

REFERÊNCIAS BIBLIOGRÁFICAS..................................................................61 
INDICE DE TABELAS

Página

Tabela 1- Estimativa do teor de umidade de equilíbrio em função da umidade relativa do ar em algumas cidades brasileiras...........................................................................9

Tabela 2- Características das fontes radioisotópicas utilizadas. ................................16

Tabela 3 - Teste do forno: umidades percentuais. .....................................................25

Tabela 4 - Densidades obtidas pelo método convencional a U\% e 12\% de umidade e diferenças percentuais obtidas.....................................................................................26

Tabela 5 - Densidades e coeficientes de absorção linear - ${ }^{241} \mathrm{Am}(59,5 \mathrm{keV})$..............27

Tabela 6 - Densidades e coeficientes de absorção linear - ${ }^{133} \mathrm{Ba}(356 \mathrm{keV})$.....................27

Tabela 7 - Densidades e coeficientes de absorção linear - ${ }^{192} \operatorname{Ir}(316 \mathrm{keV})$......................28

Tabela 8 - Densidades e coeficientes de absorção linear $-{ }^{137} \mathrm{Cs}(662 \mathrm{keV})$.....................28

Tabela 9 - Densidades e coeficientes de absorção linear - ${ }^{60} \mathrm{Co}(1170 \mathrm{keV})$...................29

Tabela10 - Comparação das densidades obtidas a $12 \%$ de umidade pelos dois

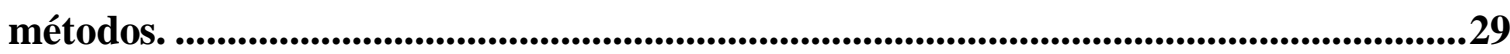

Tabela 11 - Comparação das densidades médias pelos dois métodos (por espécie)..30

Tabela 12 - Relação entre coeficientes de absorção e densidades...............................30

Tabela 13 - Valores das meias espessuras em função das energias............................. 31

Tabela 14 - Simulação de ensaios em postes (com madeira de ipê e fonte de ${ }^{137} \mathrm{Cs}$ ).39

Tabela 15 - Simulação de ensaios em árvores vivas com madeira sucupira e fonte de ${ }^{137} \mathrm{Cs}$ 


\section{INDICE DE FIGURAS}

Figura 1 - Corte transversal do tronco de uma árvore folhosa........................................4

Figura 2 - Corte de um tronco: anisotropia da madeira................................................. 5

Figura 3 - Esquema de ensaio e diagrama de valores de resistência em função dos

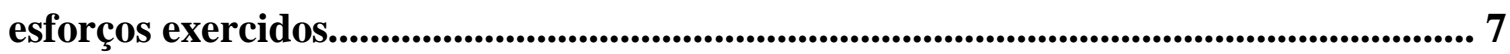

Figura 4 - Madeiras brasileiras utilizadas no trabalho .................................................13

Figura 5 - Modelos de fontes radioativas utilizadas ......................................................17

Figura 6 - Balança de precisão utilizada para pesagem dos corpos de prova .............18

Figura 7 - Forno para ensaio de umidade dos corpos de prova .................................19

Figura 8 - Dessecadores com corpos de prova de algumas espécies ensaiadas ...........20

Figura 9 - Micrômetro e paquímetro utilizados nas medidas dos corpos de prova...21

Figura 10 - Ilustração da metodologia usada nas medidas dos corpos de prova ........21

Figura 11 - Diagrama de Kollmann: densidade aparente com o teor de umidade....22

Figura 12 - Protótipo para uso em laboratório e campo(fixação em árvores) ............23

Figura 13 - Cintilador de NaI de 2" ................................................................23

Figura 14 - Espectrômetro multicanal mostrando o pico de energia do ${ }^{137} \mathrm{Cs}$............24

Figura 15 - Arranjo completo usado nos ensaios de densidade .....................................24

Figura 16 - Coeficientes de absorção linear obtidos com ${ }^{241} \mathrm{Am}$ - 59,5keV ..................32

Figura 17 - Coeficientes de absorção linear obtidos com ${ }^{133} \mathrm{Ba}-356 \mathrm{keV}$.....................33

Figura 18 - Coeficientes de absorção linear obtidos com ${ }^{192} \mathrm{Ir}-316 \mathrm{keV}$.......................34

Figura 19 - Coeficientes de absorção linear obtidos com ${ }^{137} \mathrm{Cs}$ - 662keV ....................35

Figura 20 - Coeficientes de absorção linear obtidos com ${ }^{60} \mathrm{Co}-1170 \mathrm{keV}$...................36

Figura 21 - Esquema de um poste usado pela distribuidora AWSSul (RS) ................38

Figura 22 - Gráfico para simulação de ensaios em postes $\left({ }^{137} \mathrm{Cs}\right)$................................. 39

Figura 23 - Gráfico para simulação de ensaios em árvores em pé $\left({ }^{137} \mathrm{Cs}\right)$....................40

Figura 24 - Paquímetro dendrológico .....................................................................41

Figura 25 - Árvore, folhas, flores e casca (Freijó)....................................................46

Figura 26 - Árvore e madeira (Peroba-mica) ..........................................................47

Figura 27 - Árvore e madeira (Jequitibá) ...............................................................48 
Figura 28- Árvore, tronco e casca (Muiracatiara) ....................................................49

Figura 29- Árvore e madeira (Cumaru) ..............................................................50

Figura 30- Árvore, tronco e casca (Ipê) .........................................................51/52

Figura 31- Árvore, tronco e casca (Sucupira) .............................................................55 


\section{INTRODUÇÃO}

\subsection{Importância da madeira}

Pode-se dividir a importância do estudo das madeiras obtidas de árvores brasileiras, em vários aspectos.

\subsubsection{Histórico}

As árvores brasileiras estão ligadas à história do nosso país, haja vista que o próprio nome do país é oriundo do nome de uma árvore, o pau-brasil (Caesalpinia echinata), abundante no país à época do descobrimento. A importância da flora arbórea brasileira pode ser verificada no nome de centenas de cidades espalhadas por todo território brasileiro, desde o norte, como Castanhal (PA) e Jatobá (MA); nordeste, Cedro (CE), Angicos (RN) e Angelim (PE), centro-oeste: Cumaru (GO) e Itaúba (MT), sudeste: Jequitibá (MG), Bálsamo (SP) e Cambuci (RJ), e sul: Cambará (PR), Imbuia (SC), Ipê e Canela (RS). Pode-se estender essa influência, para centenas de nomes de ruas, praças, avenidas, bem como de bairros, rios entre outros.

Cabe ainda lembrar a importância que muitas espécies representaram na vida econômica do país e em muitas de suas regiões, representando uma época e mesmo um ciclo, como por exemplo, a seringueira, o babaçu, a carnaúba, o pinheiro, o cacau e na origem de tudo, o pau-brasil.

\subsubsection{Ecológico}

A grande riqueza arbórea do Brasil, a maior do planeta, não está sendo cuidada como deveria pela sociedade civil, pelos empresários do setor madeireiro, do agronegócio e pelos governos dos diversos níveis, municipal, estadual e principalmente federal. Sem uma exploração sustentada, razão pela qual, muitas espécies já são consideradas extintas, como a peroba, jacarandá, o próprio pau-brasil, mogno e muitas outras, de grande valor ecológico e econômico. A flora nativa, interagindo com o meio ambiente há milhares de anos, passou por um processo rigoroso de seleção natural, gerando espécies resistentes e adaptadas ao meio ambiente. As matas nativas absorvem o excesso da água das chuvas, evitando que cheguem aos córregos e rios, devolvendo assim à atmosfera, sob a forma de transpiração das árvores e formando nuvens que se transformam em novas chuvas, mantendo assim o equilíbrio. As florestas nativas, especialmente as ciliares, ao longo dos rios e córregos, existentes em regiões agrícolas, desempenham funções vitais na 
manutenção da qualidade dos mananciais, absorvendo e filtrando resíduos contaminantes, evitando a contaminação das nascentes e aumentando o suprimento de água limpa dos aquíferos. A presença de matas nativas, nas encostas e ao longo dos rios, córregos, represas e lagos, contribuem de maneira decisiva para evitar o assoreamento e a destruição gradativa desses cursos de água. A grande diversidade das plantas da flora brasileira, com floração e frutificação durante todo o ano, fornece alimento à fauna e mantém sua diversidade, produzindo inimigos naturais das pragas e mantendo o equilíbrio do sistema.

\subsubsection{Econômico}

A flora brasileira possui inúmeras espécies que são cultivadas para exploração econômica, como a seringueira, o cacaueiro, cajueiro, com maior ou menor grau de importância. Outras espécies apresentam importância apenas regional, como o caso da castanha-do-pará, da pupunha e do açaí na região norte; do pequi, no cerrado, em Minas Gerais e Brasil central; do babaçu, no Maranhão; do pinhão, no sul e do palmito, da juçara, em vários pontos do litoral, principalmente no sul do país. Além disso, há o cultivo de muitas espécies, em pomares domésticos e quintais, sem cunho econômico, como pitangueiras, caramboleiras, jabuticabeiras entre outras.

A nossa flora é responsável por considerável parte da madeira consumida no mundo, cuja exploração trouxe riquezas e contribuiu significativamente para a interiorização do desenvolvimento do país. Muitas regiões já tiveram seu auge com a exploração de um tipo de árvore particular e, por conseguinte, sua madeira. Assim, por exemplo, a região norte de Santa Catarina, dependeu da exploração, por muitos anos, da imbuia (Ocotea porosa), as regiões sul e sudoeste do Paraná, do pinheiro (Araucaria 2ítida2fólia) e a região sul da Bahia, da exploração do jacarandá (Dalbergia nigra). Outros exemplos podem ser citados, como a aroeira (Lithraea molleoides) no Mato Grosso do Sul e a peroba-rosa (Aspidosperma polyneuron) no norte do Paraná.

A escassez da oferta de madeiras nobres tem estimulado cada vez mais, a invasão de áreas cada vez mais distantes do mercado consumidor interno, áreas antes inexploradas e o uso de madeiras de menor nobreza.

\subsubsection{Cultural}

Uma parte considerável das árvores plantadas nas praças, ruas, avenidas e jardins das cidades brasileiras são espécies exóticas, isto é, oriundas de outros países, fato que 
desconsidera nossa exuberante flora, de grande beleza e de excelente qualidade paisagística. É importante o uso de espécies nativas, pelos paisagistas e jardineiros, especialmente dos governos municipais, pois contribuem com o alimento para a avifauna, já acostumada com os frutos nativos, bem como resgatam muitas espécies que já se encontram no limiar da extinção.

O conhecimento de nossas árvores, suas funções, sua beleza, deve ser estendido a toda população, pois as árvores são riquezas naturais pertencentes a todos. A necessidade de produção de riqueza deve ser feita mediante um desenvolvimento sustentado, sem destruir o meio ambiente (LORENZI, 2002).

\section{2 Árvores de interesse}

Basicamente as árvores são classificadas como plantas superiores, contidas na divisão das fanerógamas, que por sua vez se divide em gimnospermas e angiospermas.

Nas angiospermas, as quais pertencem árvores e madeiras do interesse desse estudo, estão as dicotiledôneas, também conhecidas como "hardwoods" (madeiras duras), que constituem quase que totalmente as florestas tropicais. No Brasil constituem a grande maioria das madeiras utilizadas estruturalmente. As dicotiledôneas caracterizam-se pela grande variedade de espécies, mais de 4.000 e pela melhor organização vegetal em relação às coníferas. Dentre as espécies mais conhecidas popularmente pode-se citar: pau-brasil (Caesalpinia echinata), peroba-rosa (Aspidosperma polyneuron), jatobá (Hymenaea courbaril), cedro (Cedrella fissilis), imbuia (Ocotea porosa), ipê (Tabebuia serratifolia), jequitibá-rosa (Cariniana legalis), sucupira (Bowdichia 3ítida) (LORENZI, 2002). Também se inclui entre as dicotiledôneas, a espécie eucalyptus, exótica e originária da Austrália, citada com algumas características no subitem em que foi descrita a simulação em laboratório.

As árvores que deram origem às madeiras de interesse deste estudo são:

1-Freijó (Cordia goeldiana) Huber- família Boraginaceae

2-Peroba-mica (Aspidosperma populifolium) A. DC. Família Apocynaceae

3-Jequitibá (Cariniana legalis) (Mart.) Kuntze- família Lecythidaceae

4-Muiracatiara (Astronium lecointei) Ducke-família Anacadiaceae

5-Cumaru (Dipteryx odorata) (Aubl.) Willd.-família Fabaceae

6-Ipê (Tabebuia serratifolia) (Vahl.) Nichols -família Bignoniaceae

7-Sucupira (Bowdichia nítida) Spruce ex Benth-familia Fabaceae 
No ANEXO I estão descritas as principais características dessas árvores (LORENZI, 2002).

\subsubsection{Anatomia e fisiologia das árvores}

Macroscopicamente o tronco das árvores apresenta, em todas as espécies, anatomia bem definida. A primeira camada, interna à casca, é chamada de alburno e responsável pela condução ascendente da seiva bruta para os ramos superiores da árvore. Esta camada apresenta menor resistência à demanda biológica, apresentando uma coloração mais clara (FIG.1) (KLOCK, 2007).

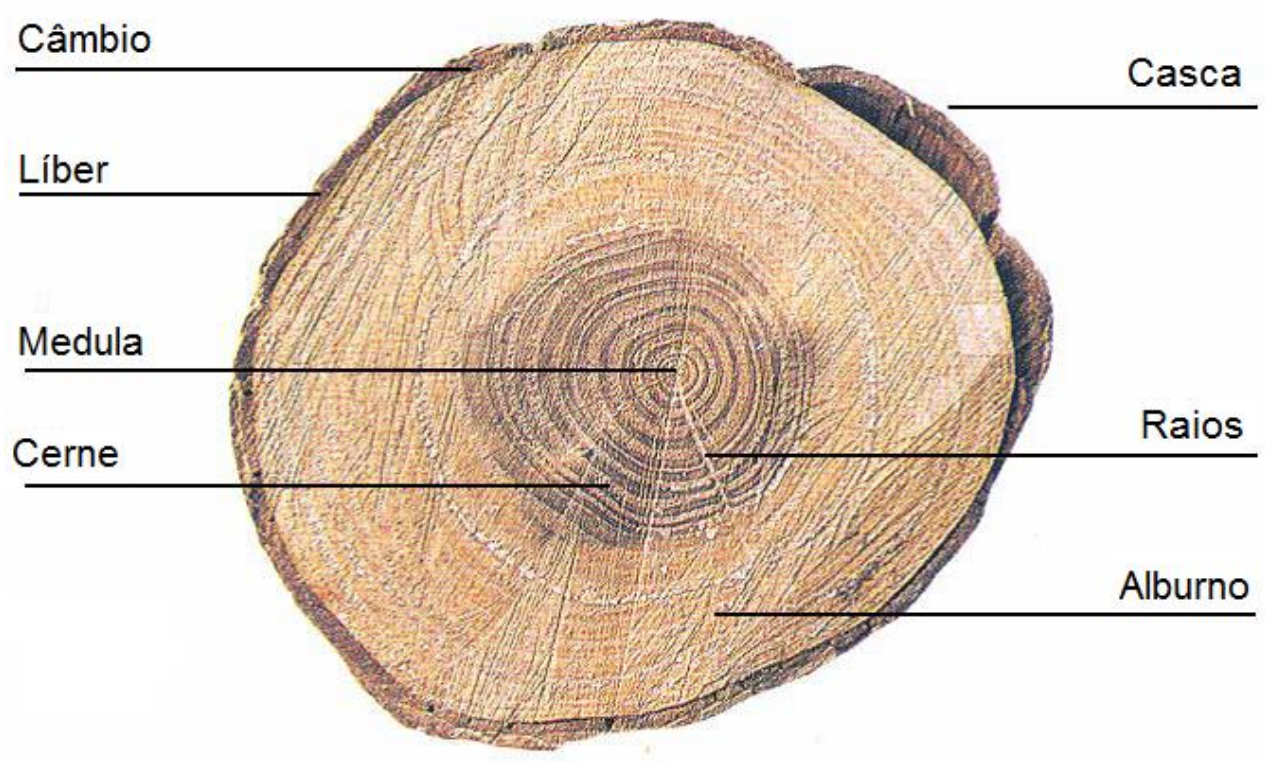

FIGURA 1 - Corte transversal do tronco de uma árvore folhosa.

A camada mais central, o cerne, é formada por camadas mais antigas e tendem a armazenar resinas, taninos e substâncias de massa molar maior, conferindo à camada, uma coloração mais escura e com maior resistência à demanda biológica.

Cada espécie de madeira apresenta um arranjo particular das diversas células que compõem o tecido lenhoso, de modo que é possível a sua identificação, quando submetida a apreciação de uma lupa ou microscópio. A espessura dos traqueídeos varia conforme a época do ano em que são formados, sendo que os mais espessos se formam durante o período de menor atividade do vegetal, ou seja, durante os períodos de dias mais curtos, temperaturas mais baixas e menor índice pluviométrico. 


\subsection{A madeira}

\subsubsection{Anatomia e fisiologia da madeira}

A composição elementar apresenta três constituintes principais: carbono (49-50\%), oxigênio (44-45\%), hidrogênio (6\%), além de nitrogênio (0,1\%-1\%), cálcio, potássio, magnésio e outros, em porcentagens ainda menores (KLOCK, 2007).

A madeira é um material produzido a partir do tecido formado pelas plantas lenhosas, com função de sustentação mecânica. Sendo um material resistente e leve, é frequentemente usado para fins estruturais e de sustentação de construções. É um material orgânico, sólido, de composição complexa, onde predominam as fibras de celulose $(45 \pm 2 \%)$, hemicelulose $(30 \pm 5 \%)$, unidas pela lignina $(20 \pm 4 \%)$ e extrativos $(3 \pm 2 \%)$. Caracteriza-se por absorver facilmente água (higroscopia) e por apresentar propriedades físicas diferentes, de acordo com a orientação espacial (anisotropia) (FIG. 2) (CARVALHO, 1996).

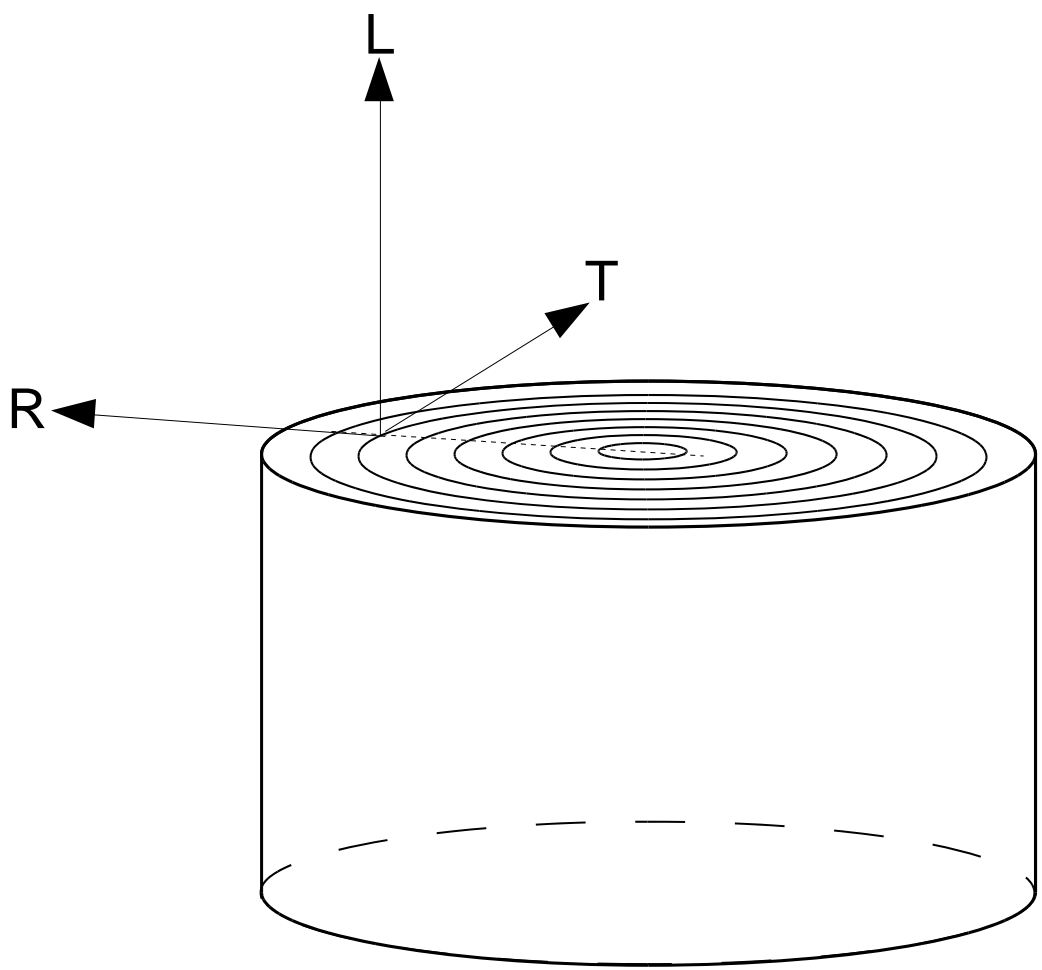

FIGURA 2 - Corte de um tronco: anisotropia da madeira 
Pela disponibilidade e características diferenciadas, a madeira foi um dos primeiros materiais a ser usado pelo homem, tendo uma grande multiplicidade de usos, diretos e indiretos. Ainda hoje é uma importante fonte de energia doméstica e industrial, além de ser matéria prima na fabricação de papel e celulose, nas indústrias químicas de modo geral, perfumaria, moveleira, naval e construção civil (casas, edifícios, pontes), fabricação de instrumentos musicais, de artigos esportivos e como sustentação na distribuição de energia elétrica.

\subsection{Propriedades da madeira}

\subsubsection{Propriedades mecânicas}

A título de ilustração, pois não é objetivo estudá-las, menciona-se a seguir as principais propriedades mecânicas da madeira, bem como um esquema mostrando a aplicação das forças e alguns dados da resistência em função dos esforços empregados (FIG. 3) (CARVALHO, 1996).

1- Em relação aos esforços principais, exercidos no sentido das fibras (coesão axial do material) sobre outro.

*Compressão: em alguns casos provoca a separação das fibras e ruptura por flambagem;

*Tração: produz contrações transversais, aumentando a aderência das fibras;

*Flexão estática;

*Flexão dinâmica ou tenacidade e

*Cisalhamento: esforço que provoca deslizamento de um plano.

2- Em relação aos esforços secundários, exercidos transversalmente às fibras (coesão transversal do material).

*Compressão: esforço de compressão no sentido normal às fibras; tensão;

*Torção e

*Fendilhamento. 


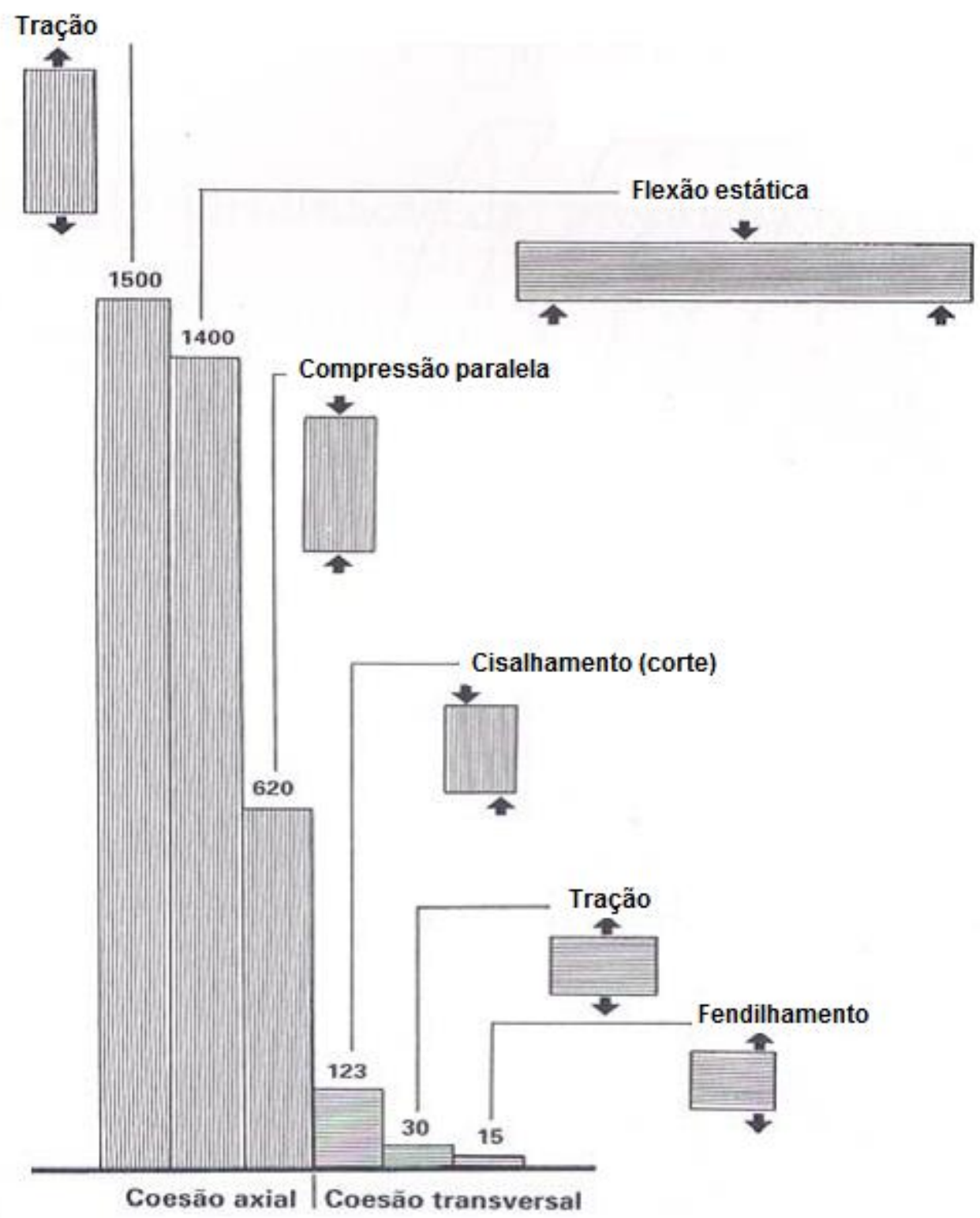

FIGURA 3 - Esquema de ensaio e diagrama de valores de resistência em função dos esforços exercidos.

\subsubsection{Propriedades físicas}

Entre as propriedades físicas pode-se citar:

*Densidade ou massa específica;

*Umidade;

*Retratibilidade;

*Condutibilidade: térmica, elétrica e sônica; 
*Dureza e

*Resistência ao fogo, a fungos e insetos e ataque químico.

Dentre as propriedades citadas, concentrou-se o estudo na densidade e umidade, pois esta última influencia direta e intensamente na densidade, que é a principal propriedade da madeira e tema central deste trabalho.

\subsubsection{Umidade}

Após a extração da árvore, a água no lenho permanece no material de três maneiras:

a- água livre ou de capilaridade, preenchendo os espaços capilares e intercelulares, com teor de aproximadamente $28 \%$ de umidade (Ponto de Saturação das Fibras - PSF);

b- água de impregnação adsorvida, impregnada nos espaços sub microscópicos da parede celular, com teores variando de $6 \%$ a $28 \%$, em camadas poli moleculares, ligadas por forças elétricas polares;

c- água de adsorção química, aderida às interfaces existentes entre as moléculas de celulose e da hemicelulose, com teores entre $0 \%$ e $6 \%$, por forças de valências secundárias monomoleculares (forças de van der Waalls e pontes de hidrogênio).

A madeira depois de serrada e deixada ao ar para secagem, tem o seu teor de umidade reduzido por evaporação, sendo a chamada água livre, a primeira a ser removida. Teoricamente, somente após a remoção de toda água capilar é que se inicia a perda de água existente entre os constituintes da parede celular, ocorrendo essa perda até atingir o valor do PSF (Ponto de Saturação das Fibras), que é em torno de $28 \%$ de umidade. A água de constituição não é eliminada com a secagem.

Muitas das propriedades da madeira não apresentam alterações, quando o teor de umidade está acima do PSF e, portanto, a água livre pouco altera a madeira, a não ser a redução de seu peso próprio, porém a partir e abaixo desse teor de umidade, algumas propriedades como dureza, flexão e compressão passam a sofrer significativas alterações em seus valores. A densidade, que é a propriedade física de interesse desse estudo, também é afetada de maneira acentuada pela umidade (ARAÚJO, 2007), daí a importância da avaliação da umidade dos corpos de prova de madeira, pelo método convenciona el nuclear. Deixando-se o material exposto ao ar até a perda da água de impregnação, diz-se que a madeira está seca e os teores de umidade variam de $15 \%$ a $17 \%$.

Após atingir esse patamar, a madeira por ser um material higroscópico, inicia uma constante troca de umidade com o meio ambiente. O seu teor de umidade tende a um 
equilíbrio dinâmico (SIMPSON, 1971), definido como umidade de equilíbrio, que é dependente da temperatura e umidade relativa do ar. As condições ambientais diferem entre locais diferentes, dependendo de muitos fatores, como por exemplo, da situação geográfica e às vezes até num mesmo local, dependendo da insolação e correntes de ar entre outros fatores. Essas variações vão condicionar a umidade de equilíbrio e, por conseguinte a densidade que como já dito, depende diretamente da umidade.

Como este estudo será realizado na cidade de São Paulo e a título comparativo, são apresentados na TAB.1, dados estimativos da umidade de equilíbrio em algumas cidades brasileiras (GALVÃO, 1975).

TABELA 1 - Estimativa do teor de umidade de equilíbrio em função da umidade relativa do ar, em algumas cidades brasileiras.

\begin{tabular}{llll}
\hline $\begin{array}{l}\text { Cidades } \\
\text { Brasileiras }\end{array}$ & $\begin{array}{l}\text { Umidade relativa } \\
\text { do } \operatorname{ar}(\%)\end{array}$ & $\begin{array}{l}\text { Temperatura média } \\
\text { anual }(\mathrm{C})\end{array}$ & $\begin{array}{l}\text { Teor de umidade } \\
\text { de equilíbrio }(\%)\end{array}$ \\
\hline Belo Horizonte & 76,5 & 21,1 & 14,9 \\
Curitiba & 80,2 & 16,5 & 16,2 \\
Recife & 81,2 & 25,5 & 16,2 \\
Rio de Janeiro & 79,1 & 23,7 & 15,6 \\
\hline São Paulo & 78,4 & 19,3 & 15,5 \\
\hline
\end{tabular}

\subsection{Teor de umidade}

O teor de umidade de uma madeira é a relação entre o peso da água contido em seu interior e o seu peso em estado completamente seco, expresso em porcentagem (\%).

$$
\mathrm{U}=\frac{\mathrm{P}_{\mathrm{u}}-\mathrm{P}_{\mathrm{S}}}{\mathrm{P}_{\mathrm{s}}} \times 100(\%)
$$

em que: $\mathrm{U}$ teor de umidade da madeira (\%);

$\mathrm{P}_{\mathrm{u}}$ é o peso da madeira úmida $(\mathrm{g})$;

$\mathrm{P}_{\mathrm{s}}$ é o peso da madeira seca $(\mathrm{g})$. 
A madeira é aquecida em forno à temperatura de $103 \pm 2^{\circ} \mathrm{C}$, até ficar completamente seca (peso constante após várias pesagens em determinados intervalos de tempo).

\subsubsection{Densidade}

O valor da densidade da madeira indica a quantidade total da parede das células de sustentação (fibras), transporte (vasos) e do armazenamento (parênquima radial e longitudinal), contida em determinado volume de madeira, incluindo a porcentagem de extrativos. Em razão das variações nas dimensões e proporção dos diversos tecidos da madeira, a densidade pode variar de $0,13 \mathrm{~g} / \mathrm{cm}^{3}$ a $1,40 \mathrm{~g} / \mathrm{cm}^{3}$ entre as espécies, entretanto a densidade da matéria lenhosa sólida varia muito pouco e pode-se admitir um valor médio de $1,50 \mathrm{~g} / \mathrm{cm}^{3}$ para todas as madeiras (KOLLMANN, CÔTÉ, 1968).

É de conhecimento dos pesquisadores de madeira, a influência de vários fatores no desenvolvimento das árvores que dão origem as madeiras: solo, clima (temperatura e umidade), altitude, latitude, isto é, fatores biológicos, geográficos, edáficos e ambientais. Por isso quando se fala em propriedades da madeira, refere-se sempre às propriedades médias, isto valendo é claro também para a densidade (FERREIRA, 1970).

Segundo Hellmeister (1982), a densidade é a propriedade física mais importante para a caracterização da madeira, apresentando como conceito físico, a quantidade de massa contida na unidade de volume. É opinião de Besley (1968), Shimoyama e Barrichelo (1991), que a densidade é um dos mais importantes parâmetros para a avaliação da qualidade da madeira por manter relação com as demais propriedades do material (DIAS e LAHR, 2004).

Segundo Cisternas (1994), a densidade aparente $\left(\rho_{\mathrm{ap}}\right)$ corresponde à densidade medida, nas condições de uma atmosfera de pressão, a $20^{\circ} \mathrm{C}$ de temperatura e $65 \%$ de umidade relativa do ar. 


\section{OBJETIVOS}

Os objetivos do trabalho podem ser divididos em:

1-Estudo da principal propriedade da madeira, a densidade ou massa específica, com radiação gama, mediante a técnica de atenuação gama (método não convencional) e comparação com os valores obtidos experimentalmente, pelo método convencional.

2- Objetivos secundários ou de suporte, que vão gerar importantes informações de cunho nuclear;

2.1- Obtenção dos coeficientes de absorção ou atenuação linear das madeiras;

2.2- Obtenção dos coeficientes de absorção mássica;

2.3- Obtenção dos valores das meias-espessuras;

3-Aplicação das curvas e parâmetros obtidos, em análise de defeitos, mediante ensaios não destrutivos, em postes de madeira (simulação em laboratório) e em árvores vivas (simulação em laboratório). 


\section{ORIGINALIDADE E CONTRIBUIÇÃO DO TRABALHO}

Os parâmetros obtidos visam à elaboração de curvas de exposição, especialmente aquelas que relacionam a energia do radioisótopo com a espessura a ensaiar da madeira, para uma determinada densidade aparente. Isto foi feito com os radioisótopos: ${ }^{241} \mathrm{Am}$, ${ }^{133} \mathrm{Ba},{ }^{192} \mathrm{Ir},{ }^{137} \mathrm{Cs}$ e ${ }^{60} \mathrm{Co}$, um cintilador de iodeto de sódio e um espectrômetro. Essas curvas viabilizarão o estudo da sanidade de postes, com diâmetros de $150 \mathrm{~mm}$ a $250 \mathrm{~mm}$ de diâmetro e árvores vivas em diâmetros que podem variar de $150 \mathrm{~mm}$ a 400mm no DAP (diâmetro a altura do peito), com simulações em laboratório, que poderão futuramente ser utilizadas em aplicações no campo. Para tanto se construiu um paquímetro dendrológico para a medida dos diâmetros das árvores e um protótipo em alumínio, ou seja, uma estrutura metálica a ser fixada ao poste ou tronco da árvore contendo a fonte e o detetor em posições diametralmente opostas e podendo ser girado, possibilitando a realização de ensaios em várias direções: norte-sul e leste-oeste, por exemplo. O protótipo aliado aos parâmetros obtidos nos objetivos preliminares, porém fundamentais, conferem ao trabalho, a originalidade requerida. 


\section{MATERIAL E MÉTODOS}

\subsection{Material}

\subsubsection{Corpos de prova}

\subsubsection{Madeira}

As madeiras foram obtidas por doação da Madeireira Amarante, sem comprovação de origem, mas segundo a empresa, com procedência principalmente de Rondônia. As madeiras foram previamente secas ao ar, na própria empresa.

Foram usados corpos de prova de sete madeiras brasileiras diferentes, cujas características principais estão mostradas no ANEXO I (LORENZI, 2002), e listadas com os nomes como são conhecidas usualmente e respectivas nomenclaturas científicas (FIG. 4):
a. Freijó (Cordia goeldiana);
b. Peroba-mica (Aspidosperma populifolium);
c. Jequitibá (Cariniana legalis);
d. Muiracatiara (Astronium lecointei);
e. Cumaru (Dipteryx odorata);
f. Ipê (Tabebuia serratifolia);
g. Sucupira (Bowdichia nítida).

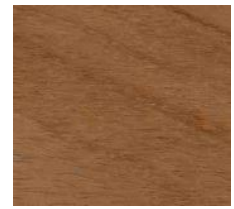

(a)

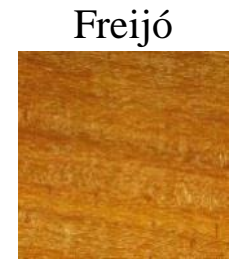

(e)

Cumaru

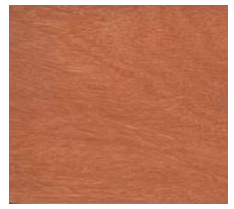

(b)

Peroba-mica

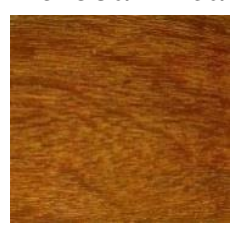

(f)

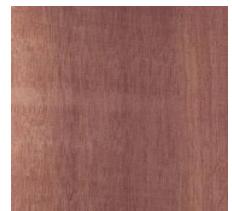

(c) Jequitibá

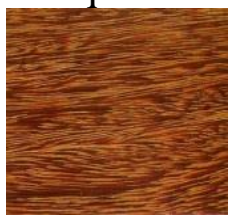

(g)

Sucupira

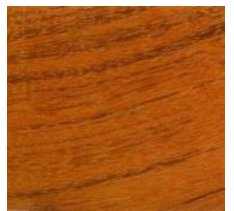

(d)

FIGURA 4 - Madeiras brasileiras utilizadas no trabalho.

Os corpos de prova para os ensaios de umidade, 40 de cada espécie foram elaborados em conformidade com a norma brasileira NBR 7190(ABNT 1997). Eles foram cortados, aplainados e lixados na marcenaria do IPEN. Posteriormente, selecionaram-se 
quinze amostras de cada espécie, de acordo com o acabamento, uniformidade de dimensões (especialmente espessuras) e ausência de defeitos.

Para os testes de forno (teor de umidade), as dimensões usadas foram: 20mmx30mmx50mm e 70mmx70mmx(A)mm, sendo A, espessuras variáveis, de $14 \mathrm{~mm}$ a $21 \mathrm{~mm}$.

\subsubsection{Acrílico}

O material usado como padrão, para o cálculo das densidades das madeiras, foi o acrílico ou polimetacrilato de metila (PMMA), um material termoplástico rígido, transparente e incolor, apresentando a fórmula molecular $\left(\mathrm{C}_{5} \mathrm{O}_{2} \mathrm{H}_{8}\right)_{\mathrm{n}}$ e temperatura de fusão entre $130^{\circ} \mathrm{C}$ e $140^{\circ} \mathrm{C}$, dependendo da pureza do material. É um material bastante estável à temperatura ambiente, sem alteração de dimensões e massa, com densidade variando entre $1,15 \mathrm{~g} / \mathrm{cm}^{3}$ a $1,19 \mathrm{~g} / \mathrm{cm}^{3}$. Como o material não foi certificado, utilizou-se a mesma metodologia que no cálculo das densidades das madeiras, ou seja, o método convencional: massa/volume. O padrão utilizado tem as dimensões de $70 \mathrm{~mm} \times 70 \mathrm{~mm}$ $\mathrm{x} 19,1 \mathrm{~mm}$ e densidade de $1,164 \mathrm{~g} / \mathrm{cm}^{3}$.

\subsubsection{Radiação Gama}

\subsubsection{Interação da radiação gama com a matéria}

Um núcleo atômico de um elemento radioativo pode basicamente emitir três tipos de radiação, as partículas alfa e beta e os raios gama. Existem algumas diferenças básicas entre a natureza desses elementos: as partículas alfa e beta possuem massa de repouso enquanto a radiação gama não possui, podendo viajar no vácuo a $300.000 \mathrm{~km} / \mathrm{s}$. As partículas alfa representam núcleos de Hélio duplamente ionizados e portanto são carregadas positivamente; as partículas beta possuem carga negativa e os raios gama não possuem carga e por isso interagem com a matéria de modos diferentes.

Há vários processos de interação da radiação gama com a matéria, sendo os mais importantes: efeito fotoelétrico, efeito Compton e produção de pares.

No efeito fotoelétrico, o fóton é completamente absorvido e toda a sua energia incidente é transferida a um elétron ligado ao átomo. Dependendo do valor da energia, o elétron pode ser deslocado para outra camada eletrônica ou removido do átomo. $\mathrm{O}$ efeito fotoelétrico ocorre preferencialmente na camada $\mathrm{K}$ do átomo e esse vazio na camada, é preenchido por outro elétron de uma camada mais periférica, com a emissão de um raio X. A atenuação 
fotoelétrica varia de maneira complexa com a energia do fóton e com o valor de $\mathrm{Z}$ (número atômico) do absorvedor, ou seja, é maior para baixas energias e cresce rapidamente com o aumento do número atômico do átomo em questão.

O efeito ou espalhamento Compton é uma interação entre o fóton incidente e um elétron com baixa energia de ligação ou livre. Ao contrário do efeito fotoelétrico, o Compton geralmente envolve elétrons de camadas mais externas do átomo e fornece apenas uma fração da sua energia, porém suficiente para a remoção de sua camada eletrônica.

Na produção de pares, o fóton interage com o campo de força nuclear do átomo e desaparece completamente. Há a criação de um par elétron-pósitron, ou seja, transformação de energia em matéria. A energia de $1,02 \mathrm{MeV}$ é limiar para o processo, sendo esta energia, equivalente a da massa de repouso necessária para criar o par elétronpósitron, ocorrendo no caso das fontes radioativas usadas neste trabalho, somente para o ${ }^{60} \mathrm{Co}$, cujas energias estão acima desse valor $(1,02 \mathrm{MeV})$. Ao final desse processo, o pósitron produzido irá interagir com um elétron, produzindo dois fótons com $0,511 \mathrm{MeV}$ cada um. Esses fótons podem ou não escapar do sistema e escapando podem ser absorvidos segundo os processos fotoelétrico ou Compton.

\subsubsection{Fontes radioativas}

\subsection{Produção das fontes radioativas}

\section{Cobalto}

O cobalto é produzido em reatores nucleares com nêutrons térmicos a partir do cobalto metálico, de massa atômica 59 e número atômico 27 , segundo a reação nuclear:

$$
{ }^{59} \mathrm{Co}_{27}+{ }^{1} \mathrm{n}_{\mathrm{o}} \rightarrow{ }^{60} \mathrm{Co}_{27}+\gamma
$$

\section{Césio}

O césio é um elemento químico cujo símbolo é Cs, com massa atômica 137 e número atômico 52 , é produto de fissão do ${ }^{235} \mathrm{U}$, obtido por separação química.

\section{Irídio}

O irídio é um elemento químico cujo símbolo é Ir, de massa atômica 191 e número atômico 77 (77 prótons e 77 elétrons). O irídio radioativo $\left({ }^{192} \mathrm{Ir}\right)$ é produzido em reatores nucleares, com nêutrons térmicos, a partir do seu isótopo natural, metálico segundo a reação nuclear:

$$
{ }^{191} \operatorname{Ir}_{77}+{ }^{1} \mathrm{n}_{\mathrm{o}} \rightarrow{ }^{192} \operatorname{Ir}_{77}+\beta+\gamma
$$




\section{Amerício}

O amerício é um elemento químico cujo símbolo é Am, com massa atômica 243 e número atômico 95 (95 prótons e 95 elétrons. O amérício é obtido em reatores de potência como produto do decaimento do ${ }^{241} \mathrm{Pu}$, segundo as reações nucleares:

$$
\begin{aligned}
& { }^{238} \mathrm{U}_{92}+{ }^{1} \mathrm{n}_{\mathrm{o}} \rightarrow{ }^{239} \mathrm{U}_{92} \rightarrow{ }^{239} \mathrm{~Np}_{93}+\beta \\
& { }^{239} \mathrm{~Np}_{93}+{ }^{1} \mathrm{n}_{\mathrm{o}} \rightarrow{ }^{240} \mathrm{~Np}_{93} \rightarrow{ }^{240} \mathrm{Pu}_{94}+\beta \\
& { }^{240} \mathrm{Pu}_{94}+{ }^{1} \mathrm{n}_{\mathrm{o}} \rightarrow{ }^{241} \mathrm{Pu} \rightarrow{ }^{241} \mathrm{Am}_{95}+\beta
\end{aligned}
$$

\section{Bário}

O bário é um elemento químico cujo símbolo é Ba, com massa atômica 133 e número atômico 56 (56 prótons e 56 elétrons).

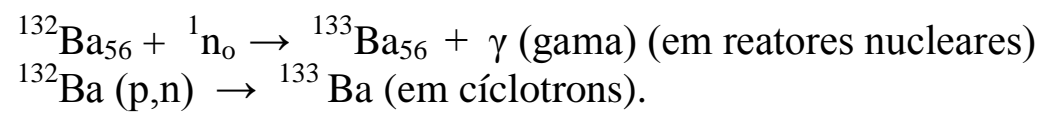

\subsection{Características das fontes radioativas}

Para a obtenção dos coeficientes de absorção linear e densidades foram utilizadas as seguintes fontes emissoras gama, cujos nomes, símbolos e características principais

\begin{tabular}{|c|c|c|c|c|c|}
\hline $\begin{array}{l}\text { Radioisotopo } \\
\text { Nome/notação }\end{array}$ & $\begin{array}{l}\text { Faixa de } \\
\text { energias } \\
(\mathrm{MeV})\end{array}$ & $\begin{array}{l}\text { Energia } \\
\text { média } \\
(\mathrm{MeV})\end{array}$ & $\begin{array}{l}\text { Atividade } \\
\text { inicial } \\
\mu \mathrm{Ci} / \mathrm{Bq} \\
\text { Data }\end{array}$ & $\begin{array}{l}\text { Constante } \\
\text { específica } \\
\mathrm{Ci} / \mathrm{GBq}\left({ }^{*}\right)\end{array}$ & $\begin{array}{l}\text { Meia vida } \\
a=\text { anos } \\
d=\text { dias }\end{array}$ \\
\hline $\begin{array}{l}\text { Amerício } \\
\left({ }^{241} \mathrm{Am}\right)\end{array}$ & $\begin{array}{l}0,0119- \\
0,0595\end{array}$ & 0,035 & $\begin{array}{l}20,43 / \\
75,6 \times 10^{4} \\
01 / 2002\end{array}$ & $\begin{array}{l}0,13 / \\
0,035\end{array}$ & $432,2 \mathrm{a}$ \\
\hline $\begin{array}{l}\text { Bário } \\
\left({ }^{133} \mathrm{Ba}\right)\end{array}$ & $\begin{array}{l}0,031- \\
0,383\end{array}$ & 0,157 & $\begin{array}{l}20,14 / \\
74,5 \times 10^{4} \\
01 / 2002\end{array}$ & $\begin{array}{l}0,44 / \\
0,119\end{array}$ & $10,54 \mathrm{a}$ \\
\hline $\begin{array}{l}\text { Irídio } \\
\left({ }^{192} \mathrm{Ir}\right)\end{array}$ & $\begin{array}{l}0,136- \\
1,060\end{array}$ & 0,377 & $\begin{array}{l}330 / \\
1221 \times 10^{4} \\
11 / 2011\end{array}$ & $\begin{array}{l}0,48 / \\
0,13\end{array}$ & $73,83 \mathrm{~d}$ \\
\hline $\begin{array}{l}\text { Césio } \\
\left({ }^{137} \mathrm{Cs}\right)\end{array}$ & $\begin{array}{l}0,0322- \\
0,662\end{array}$ & 0,615 & $\begin{array}{l}228 / \\
843 \times 10^{4} \\
04 / 2012\end{array}$ & $\begin{array}{l}0,34 / \\
0,089\end{array}$ & $30,14 \mathrm{a}$ \\
\hline $\begin{array}{l}\text { Cobalto } \\
\left({ }^{60} \mathrm{Co}\right)\end{array}$ & $\begin{array}{l}1,179- \\
1,330\end{array}$ & 1,250 & $\begin{array}{l}20,81 / \\
76,9 \times 10^{4} \\
01 / 2002\end{array}$ & $\begin{array}{l}1,30 / \\
0,36\end{array}$ & 5,29 a \\
\hline
\end{tabular}
estão apresentadas na TAB.2 e em maiores detalhes no ANEX

TABELA 2 - Características das fontes radioisotópicas utilizadas

OBS: (*) - Constante de ionização; (SANCHEZ, 1974). 
Diferentemente da fonte de irídio, montada com discos metálicos $(3,00 \mathrm{~mm}$ de diâmetro e 0,25mmm de espessura) e selada em aço inoxidável, as demais fontes foram fabricadas por deposição química e montadas sobre uma resina epóxi, nas dimensões de 1 ”'(25,4mm) de diâmetro, 1/4”(6,35mm) de espessura e com foco de 3,5mm (FIG 5).

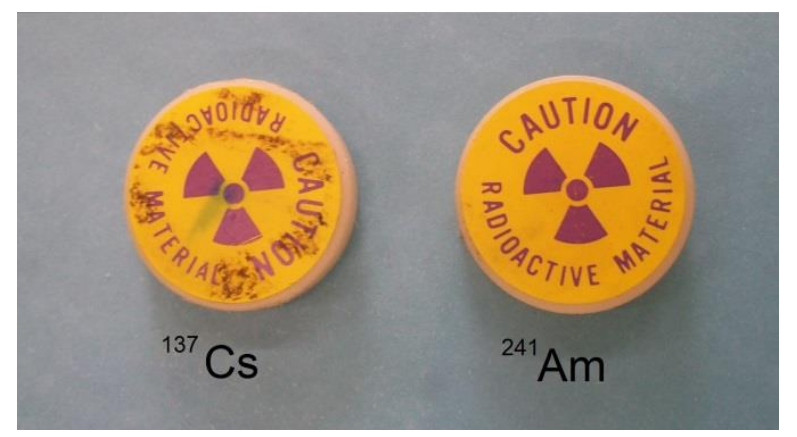

FIGURA 5 - Modelos de fontes radioativas utilizadas (à esquerda ${ }^{137} \mathrm{Cs}$ e à direita ${ }^{241} \mathrm{Am}$ )

\subsection{Métodos}

\subsubsection{Determinação da umidade}

Existem vários métodos para a determinação do teor de umidade da madeira, denominados convencionais e não convencionais. Dentre os métodos convencionais, utilizou-se o método das pesagens, no qual a amostra com teor de umidade desconhecida é pesada $\left(\mathrm{P}_{\mathrm{u}}\right)$, posteriormente levada ao forno para secagem completa e novamente pesada até peso constante (Ps). Este processo apesar de trabalhoso e demorado, porque é feito por bateladas é considerado um ensaio de ótima precisão e é o mais utilizado em laboratório.

Para a determinação da umidade em forno foram efetuados sete testes, um para cada espécie de madeira, para melhor controle da operação. A madeira foi aquecida em um forno com ventilação forçada, à temperatura de $103 \pm 2{ }^{\circ} \mathrm{C}$, com controle digital, até ficar completamente seca (peso constante após várias pesagens em determinados intervalos de tempo).

Determinou-se o peso da água removida $\left(\mathrm{P}_{\mathrm{u}}-\mathrm{P}_{\mathrm{s}}\right)$, mediante o uso da balança de precisão Metler (FIG.6) e relacionou-se este valor com o peso da madeira seca $\left(\mathrm{P}_{\mathrm{s}}\right)$, obtendo-se o valor do teor de umidade,. usando-se a equação (1) , citada em 1.4.2.1.1. 


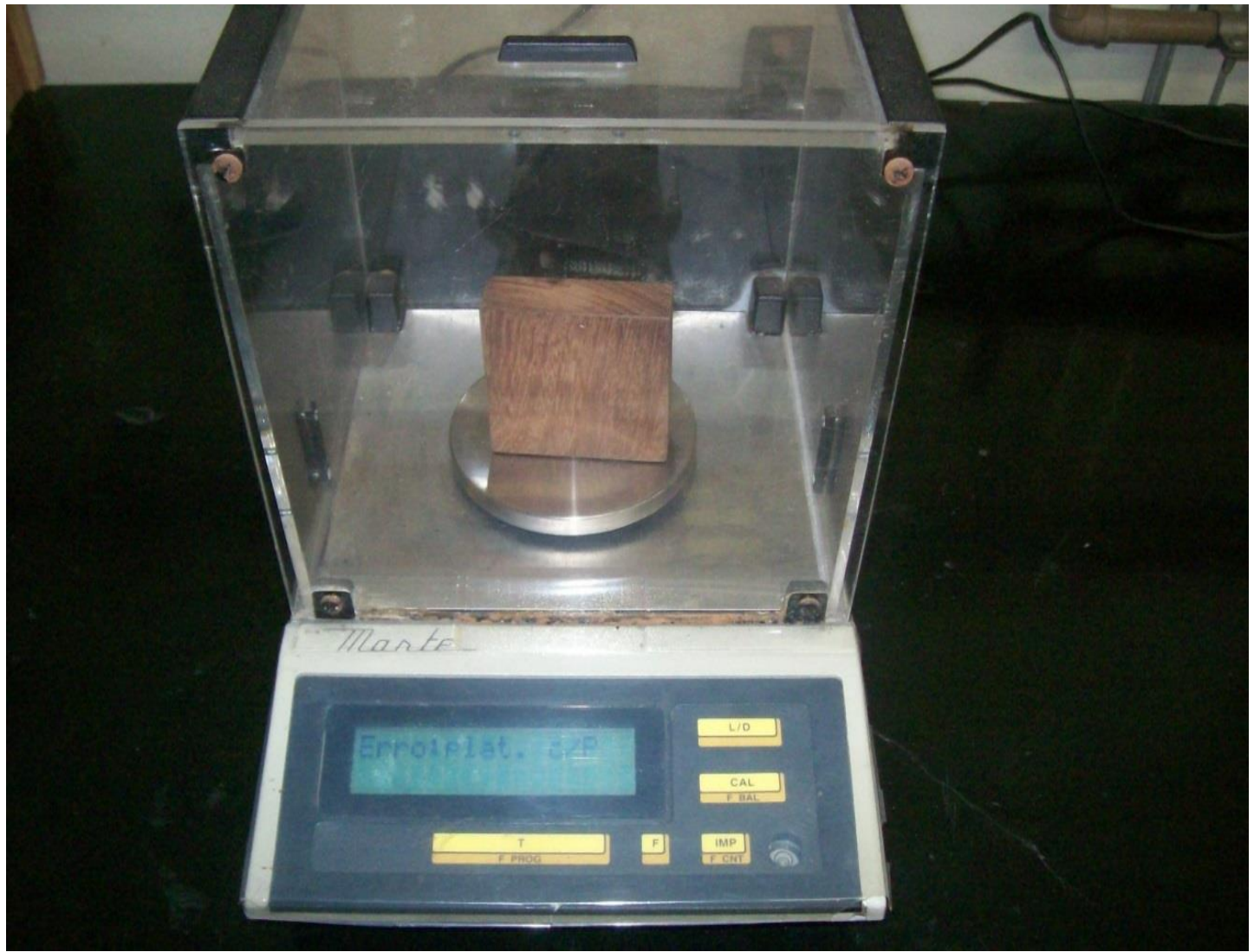

FIGURA 6 - Balança de precisão utilizada para pesagem dos corpos de prova.

Os testes foram realizados aquecendo as amostras em um forno marca Etil, com capacidade de até $900^{\circ} \mathrm{C}$, com ventilação forçada e termostato digital (FIG 7).

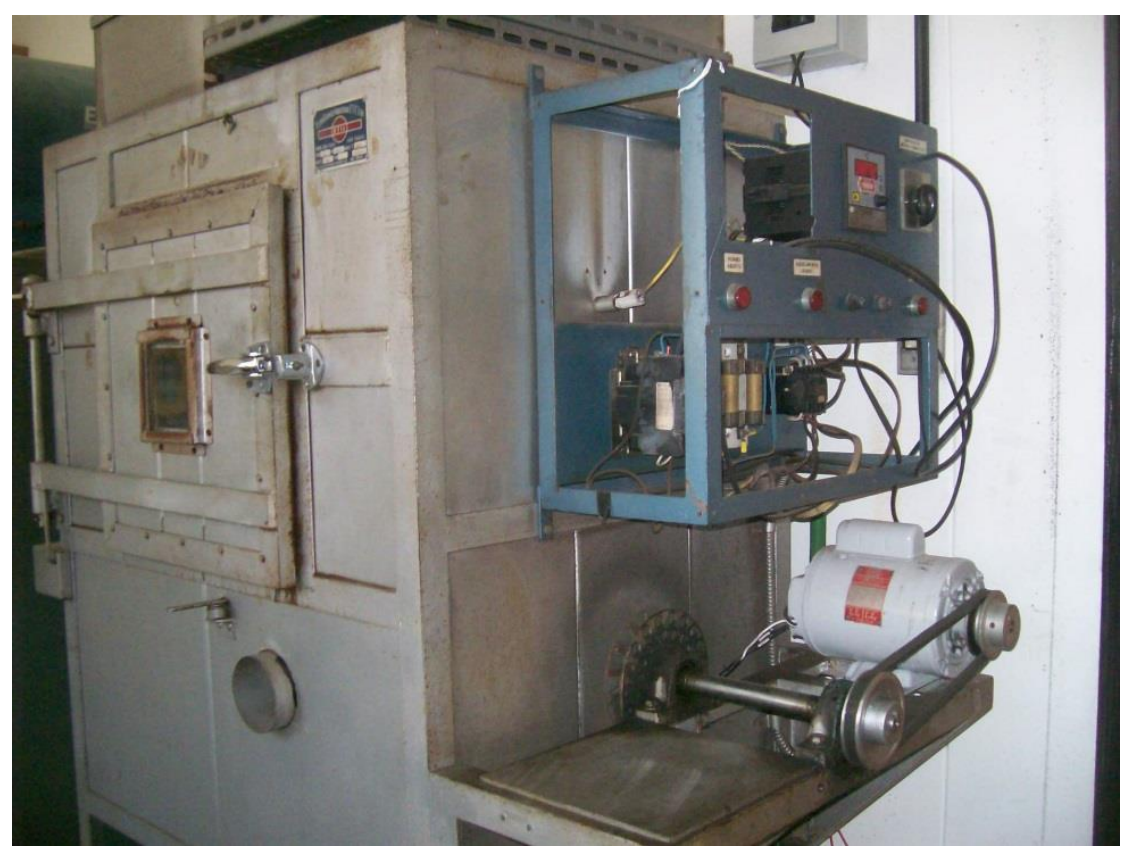

FIGURA 7 - Forno para ensaio de umidade dos corpos de prova. 


\subsubsection{Determinação das densidades}

A literatura apresenta vários métodos de determinação da densidade da madeira. Um método que usualmente envolve a determinação independente da massa e do volume é referido como determinação gravimétrica. $\mathrm{O}$ volume pode ser determinado mediante medidas lineares, com o uso de paquímetro e/ou micrômetro ou mais comumente, pelo deslocamento com a submersão da amostra em água ou outros fluidos.

Os métodos de determinação da densidade com raios-X e especialmente com partículas $\beta$ (Sr-90), têm como limitação, o ensaio de amostras com pequenas espessuras, porém são bastante precisos. Para espessuras maiores, é necessária a utilização de radiação gama, pois dependendo da energia do radioisótopo e da sensibilidade do detector ou do filme, podem-se ensaiar amostras de até $1.000 \mathrm{~mm}$ de espessura, com as limitações e inconveniências que oportunamente serão analisadas.

Neste trabalho a proposição foi estudar as propriedades físicas da madeira, densidade e umidade e obtenção de alguns parâmetros nucleares, como coeficiente de atenuação linear e meia-espessura, com diversos radioisótopos, para comparação com dados de métodos convencionais. A técnica nuclear pode ser de dois tipos:

1- de absorção ou atenuação gama (fonte e detector);

2- densitometria ou gamagrafia (fonte e filme radiográfico).

Ambas as técnicas estão baseadas no fenômeno da atenuação da radiação e descritas segundo a Lei de Lambert-Beer adaptada, uma vez que raramente se trabalha com feixes paralelos e monocromáticos na prática.

A equação é a seguinte:

$I=I_{0} \cdot e^{-\mu x}$

em que:

$\mathrm{I}_{\mathrm{o}}$ é a intensidade do feixe incidente, isto é, antes da interação com o material,

I é a intensidade do feixe emergente, isto é, após a interação com o material,

$\mathrm{x}$ é a espessura do material (cm),

$\mu$ é o coeficiente de atenuação linear do material $\left(\mathrm{cm}^{-1}\right)$.

Por extensão de conceito, as intensidades dos feixes de radiação ( $\left(\mathrm{e} \mathrm{I}_{0}\right.$ ) podem ser substituídas por contagens obtidas com as fontes radioativas, com corpo e sem corpo de prova $\left(\mathrm{C}\right.$ e $\left.\mathrm{C}_{0}\right)$ e dessa maneira pode-se obter os coeficientes de atenuação linear das 
madeiras envolvidas nos ensaios. Da mesma maneira pode-se determinar a intensidade emergente, por cálculo e também na prática, adicionando ou subtraindo matéria aos corpos de prova originais e assim, obter-se os valores das meias espessuras das madeiras ensaiadas. As densidades foram determinadas posteriormente comparando-se os valores obtidos, com um padrão de acrílico.

\subsubsection{Determinação dos coeficientes de absorção linear e densidades}

Os corpos de prova após o teste de umidade foram colocados em dessecadores com sílica-gel (FIG. 8) para a preservação das umidades obtidas no teste do forno .

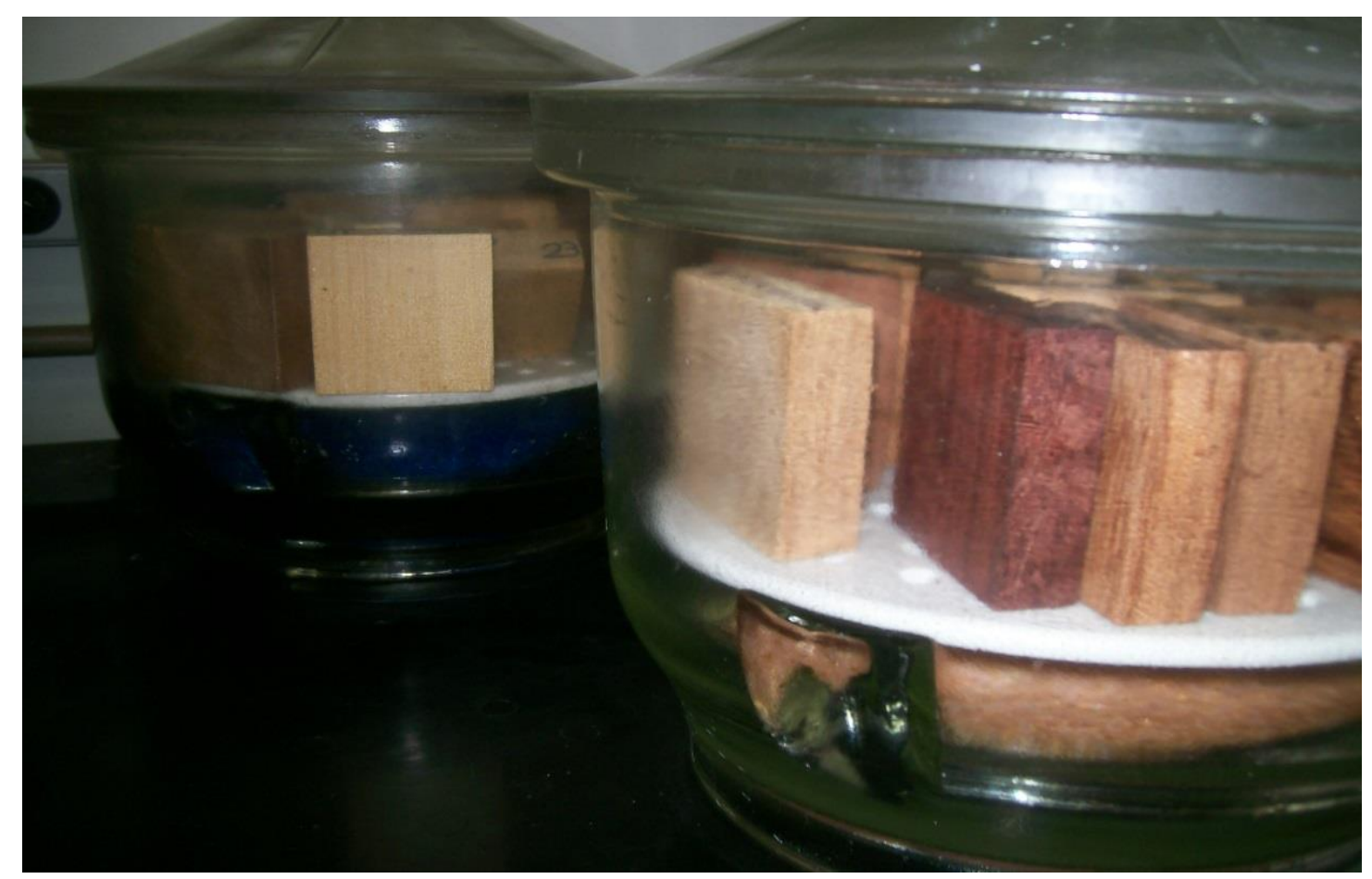

FIGURA 8- Dessecadores com corpos de prova de algumas espécies ensaiadas

Os resultados obtidos nos testes do forno para ambas as dimensões, foram muito próximos, o que nos levou a usar os corpos de prova com dimensões maiores nos ensaios para obtenção das densidades pelos métodos convencional e nuclear. Além disso, para estudo de diferentes absorções da radiação gama, corpos de prova maiores facilitaram a montagem e cobriram uma área maior do detector.

Primeiramente foram determinadas as densidades dos corpos de prova pelo método convencional $($ densidade $=$ massa/volume $)$, com os mesmos corpos de prova utilizados nos testes de umidade (15 em média), mediante medidas feitas com um micrômetro digital 
Mitutoyo, resolução 0,001mm, paquímetro digital Digimess, com resolução de $0,001 \mathrm{~mm}$ (FIG. 9). e pesagens com uma balança de precisão Metler, a mesma usada para a determinação da umidade das amostras (FIG 6), com resolução de 0,001g. As medidas das dimensões dos corpos de prova, foram feitas em cinco pontos, para a altura (h1 a h5) e largura (v1 a v5) e em 24 pontos, para a espessura, sempre da esquerda para a direita e de cima para baixo, no sentido horário (1 a 24), como mostrado na FIG. 10.
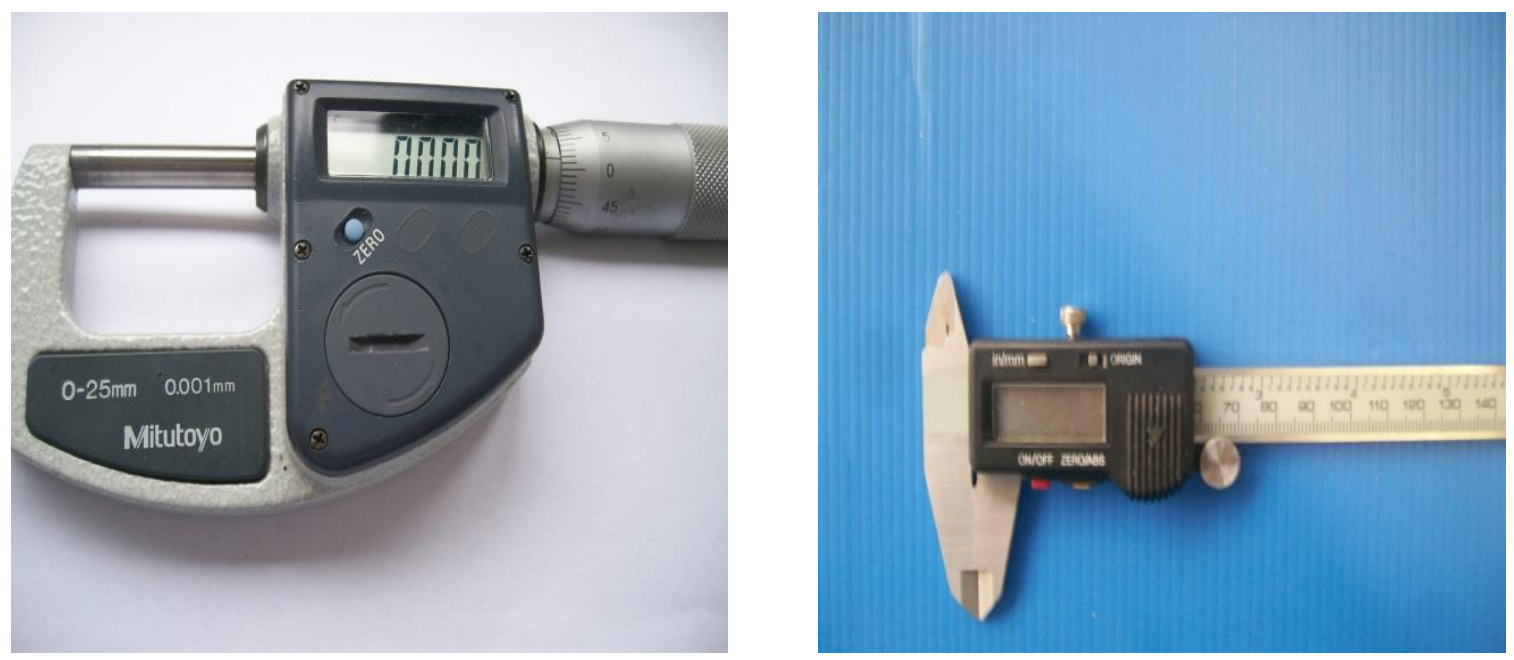

FIGURA 9-Micrômetro e paquímetros utilizados nas medidas dos corpos de prova

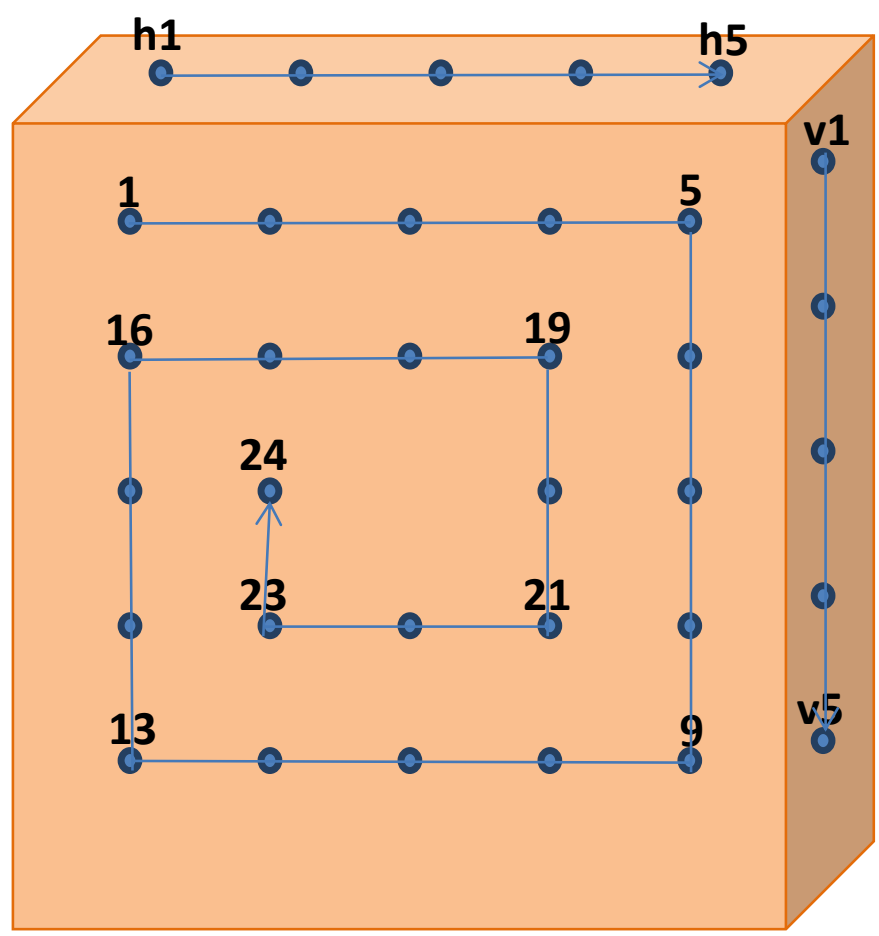

FIGURA 10 - Ilustração da metodologia usada nas medidas dos corpos de prova 
Os valores obtidos a U\% (valores obtidos no teste de umidade) podem ser convertidos à umidade desejada, 12\%, usando-se o diagrama de Kollmann, conforme a FIG. 11 .

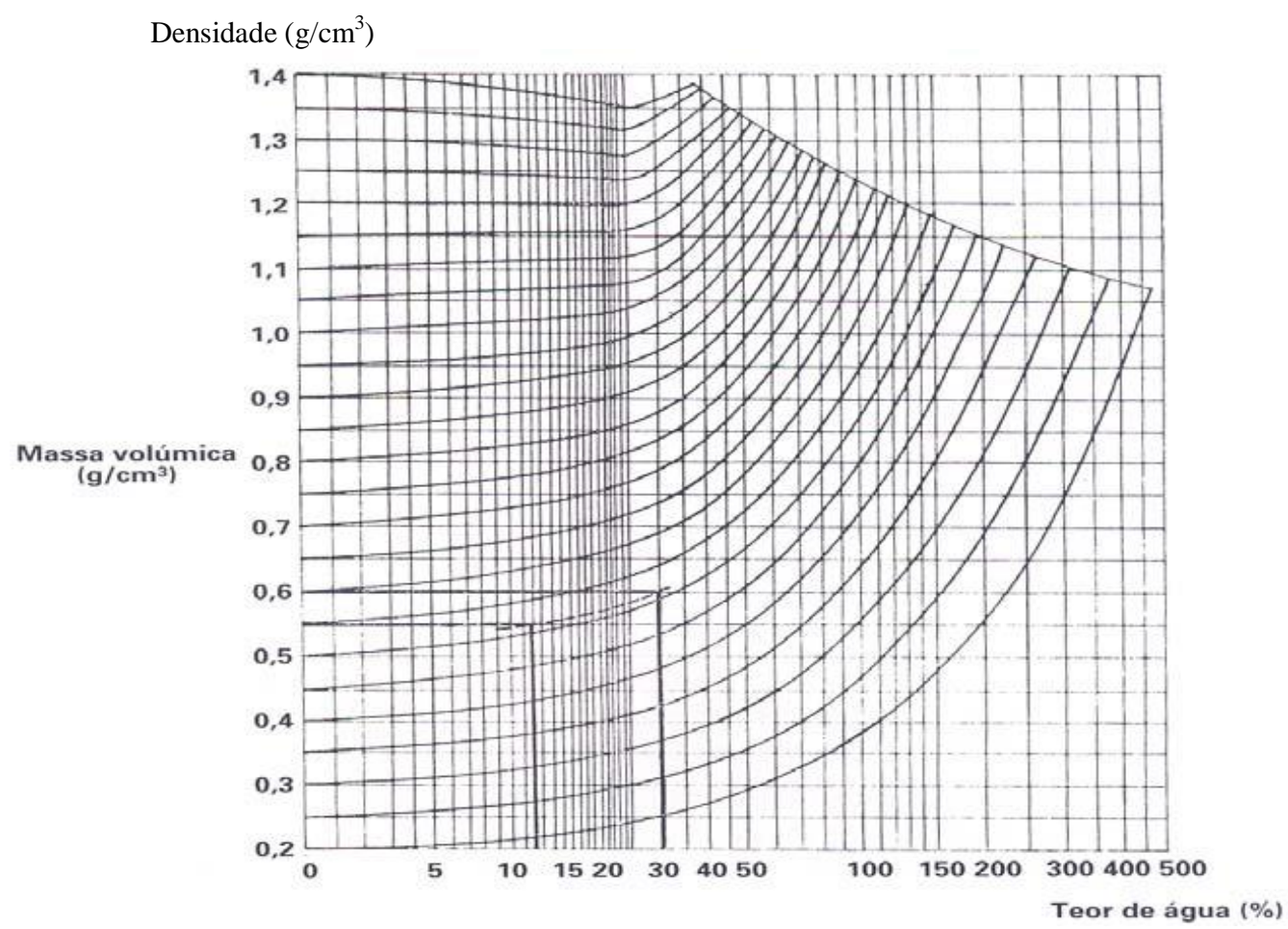

FIGURA 11 - Diagrama de Kollmann: variação da densidade aparente com o teor de umidade (Kollmann, Côté, 1984)

Neste trabalho optou-se por usar a equação 3 simplificada apresentada por Brochard (1960), pela facilidade na obtenção dos resultados os quais foram semelhantes.

$$
\rho_{12}=\rho_{\mathrm{U} \%}\left(\frac{1+12 / 100}{1+\mathrm{U} / 100}\right)
$$

em que:

$\rho_{12}$ é a densidade aparente em $\mathrm{g} / \mathrm{cm}^{3}$, ao teor de umidade de $12 \%$;

$\rho_{\mathrm{U} \%}$ é a densidade aparente, em $\mathrm{g} / \mathrm{cm}^{3}$, ao teor de umidade $\mathrm{U} \%$;

U\% é o teor de umidade obtido nos testes do forno.

Para a determinação das densidades pelo método nuclear, utilizou-se as fontes radioativas, ${ }^{241} \mathrm{Am},{ }^{133} \mathrm{~B},{ }^{192} \mathrm{Ir},{ }^{137} \mathrm{Cs}$ e ${ }^{60} \mathrm{Co}$, um protótipo para laboratório e campo (FIG. 12), um cintilador de NaI de 2", Ludlum modelo 44-10 (FIG. 13) e um espectrômetro Novelec modelo SM 512 multicanal (FIG.14). Foram ensaiados quinze corpos de prova de cada espécie de $70 \mathrm{mmx} 70 \mathrm{mmx}(\mathrm{A}) \mathrm{mm}$, sendo A(espessura), variando de $14 \mathrm{~mm}$ a $21 \mathrm{~mm}$. O arranjo montado com os componentes citados pode ser visto na FIG. 15. Utilizando-se a equação (2), substituídas as intensidades I e Io pelas contagens C e Co e aplicando-se 
logaritmo neperiano aos dois membros da equação, obtêm-se os valores dos coeficientes de absorção linear das madeiras. Relacionando-se estes com o valor do coeficiente de absorção e densidade do padrão acrílico, obtêm-se as densidades das madeiras, que também foram corrigidas, empregando-se a equação (3) juntamente com os coeficientes de absorção linear.

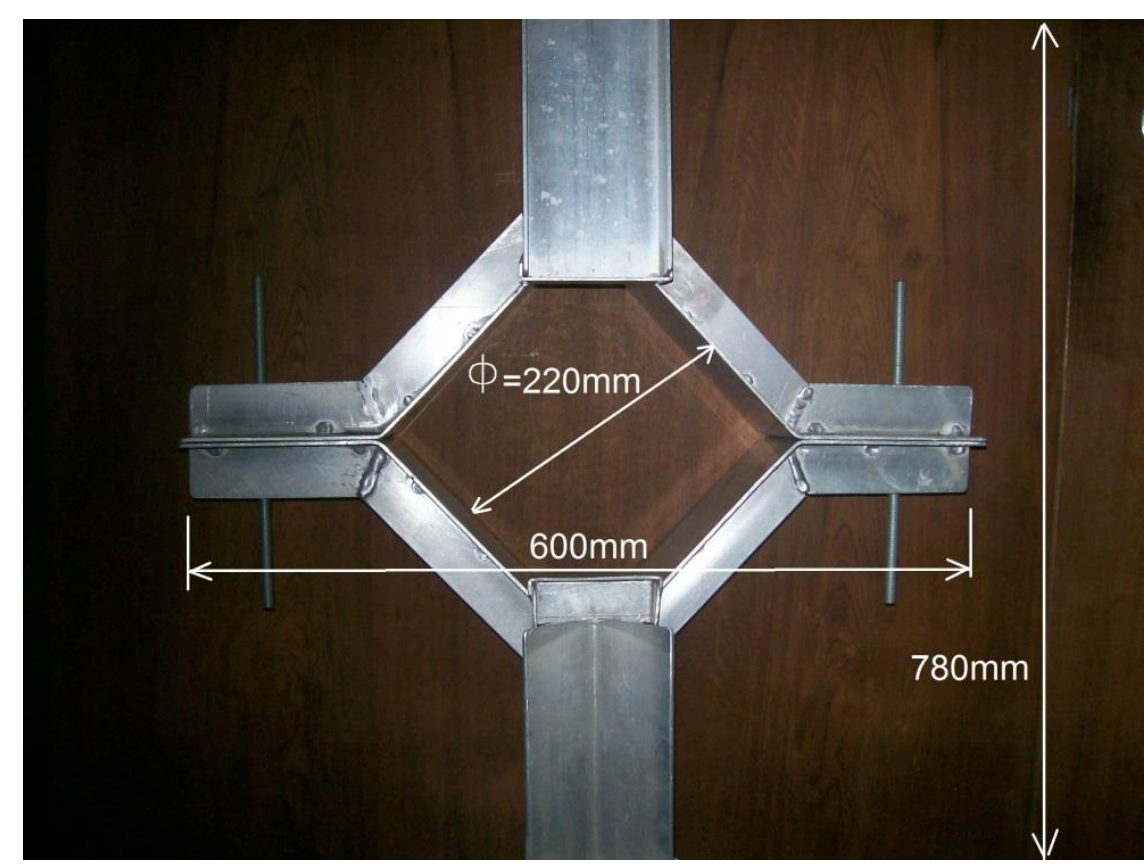

FIGURA 12 - Protótipo para uso em laboratório e campo (fixação em árvores)

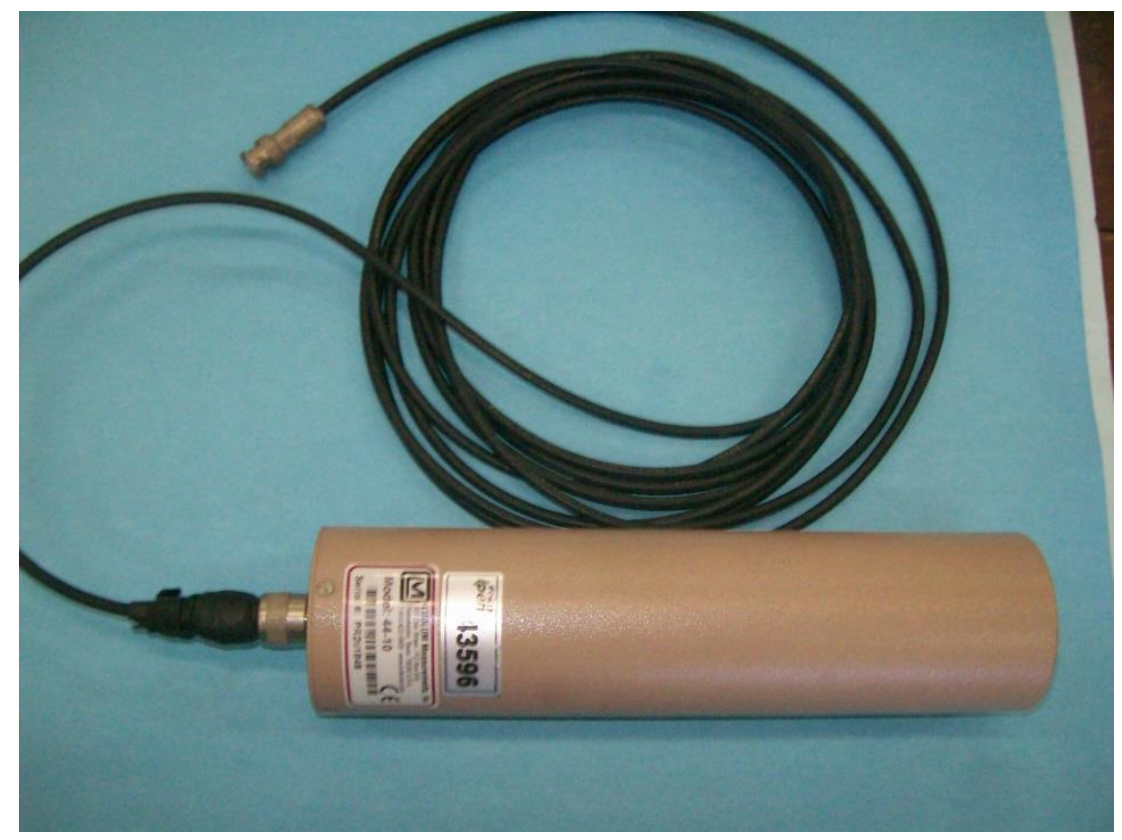

FIGURA 13 - Cintilador de NaI de 2".] 


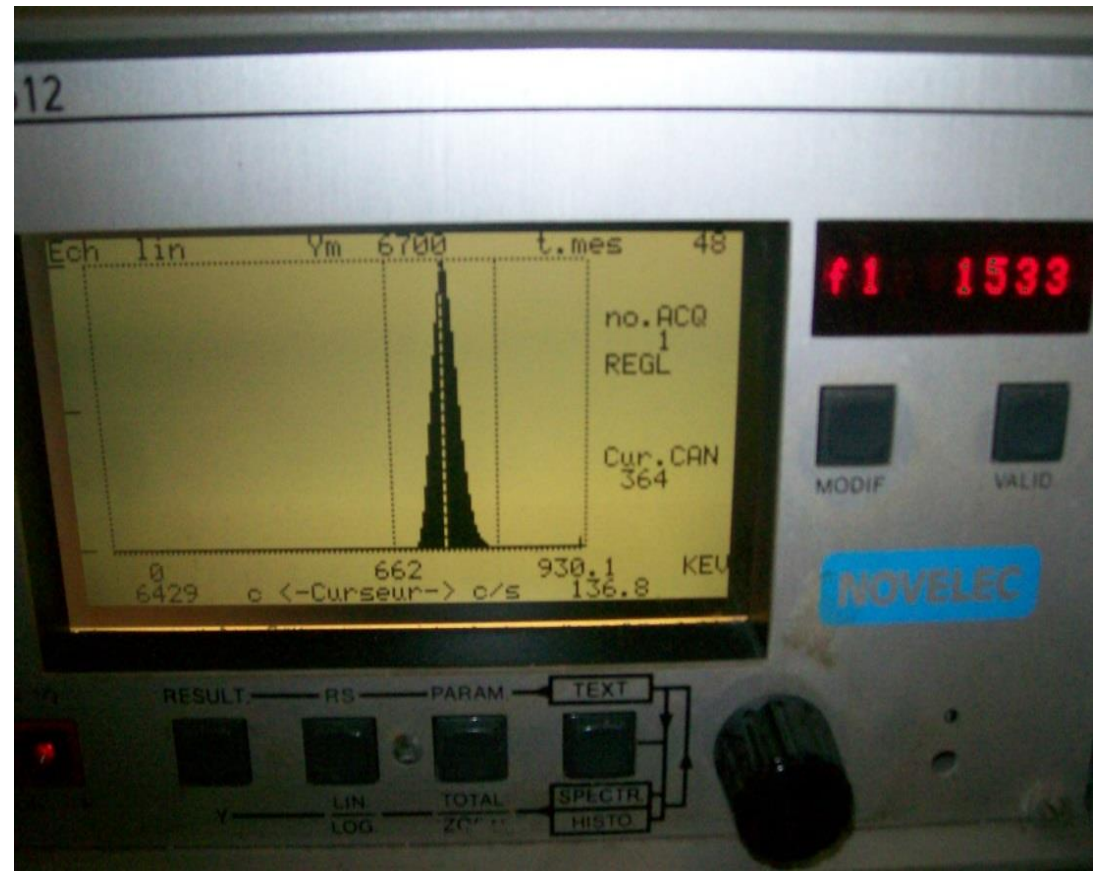

FIGURA 14 - Espectrômetro multicanal mostrando o pico de energia do ${ }^{137}$ Cs.

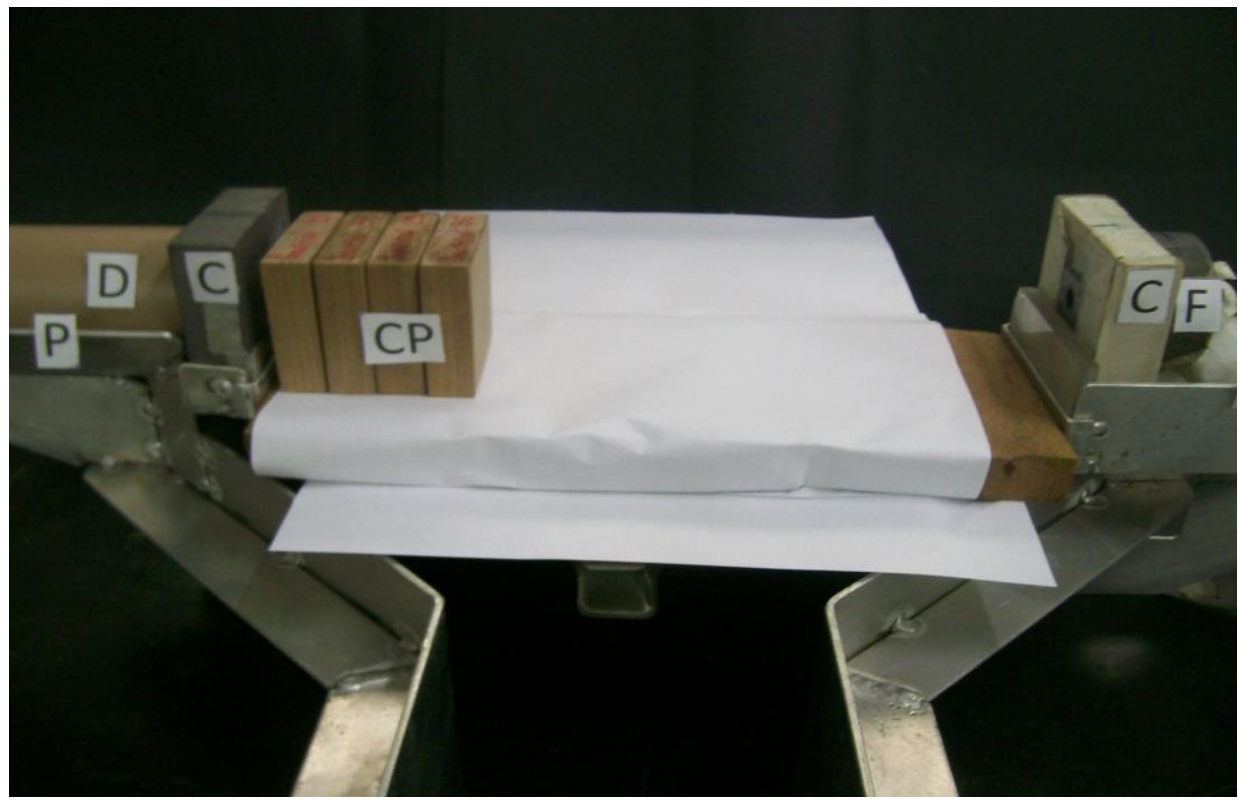

FIGURA 15 - Arranjo completo usado nos ensaios de densidade

Neste arranjo têm-se:

C- colimadores de chumbo junto à fonte e ao detetor;

$\mathrm{CP}$ - corpos de prova dispostos para ensaio;

D- detector de NaI:

F- fonte radioativa blindada;

P- protótipo para ensaios em laboratório e campo. 


\section{RESULTADOS E DISCUSSÃO}

\subsection{Determinação do teor de umidade}

Os valores médios encontrados de umidade para as diferentes espécies de madeira estão apresentados na TAB. 3 e foram obtidos como descrito em 4.2.1.

TABELA 3 - Teste do forno: umidades percentuais calculadas

\begin{tabular}{lll}
\hline Madeira (Espécie) & Umidade $(\%)$ & Desvio padrão \\
\hline Freijó & 12,635 & 0,061 \\
Peroba-mica & 13,123 & 0,066 \\
Jequitibá & 13,697 & 0,020 \\
Muiracatiara & 13,513 & 0,055 \\
Cumaru & 11,972 & 0,089 \\
Ipê & 13,248 & 0,087 \\
Sucupira & 12,475 & 0,055 \\
\hline
\end{tabular}

Os valores encontrados para as umidades dos corpos de prova, conforme a TAB. 3, são bastante próximos entre si e próximos da umidade a $12 \%$, que é o teor que serviu de base para este trabalho. Não se encontrou na literatura, quaisquer dados, ainda que médios, que pudessem balizar estes resultados obtidos.

\subsection{Determinação das densidades pelo método convencional}

Os resultados das densidades pelo método convencional e seus respectivos desvios padrões e as densidades corrigidas a 12\% de umidade, estão apresentadas na TAB. 4. 
TABELA 4 - Densidades obtidas pelo método convencional a U\% e 12\% de umidade e diferenças porcentuais obtidas.

\begin{tabular}{lllll}
\hline $\begin{array}{l}\text { Madeira } \\
\text { (Espécie) }\end{array}$ & $\begin{array}{l}\text { Densidade U\% } \\
\text { de umidade } \\
\left(\mathrm{g} / \mathrm{cm}^{3}\right)\end{array}$ & $\begin{array}{l}\text { Desvio } \\
\text { padrão }\end{array}$ & $\begin{array}{l}\text { Densidade 12\% } \\
\text { de umidade } \\
\left(\mathrm{g} / \mathrm{cm}^{3}\right)\end{array}$ & $\begin{array}{l}\text { Diferenças } \\
\text { porcentuais }(\%) \\
\mathrm{D}_{\mathrm{U}} / \mathrm{D}_{12}\end{array}$ \\
\hline Freijó & 0,581 & 0,021 & 0,578 & $(+) 0,52$ \\
Peroba-mica & 0,698 & 0,012 & 0,691 & $(+) 1,00$ \\
Jequitibá & 0,760 & 0,016 & 0,749 & $(+) 1,47$ \\
Muiracatiara & 0,874 & 0,001 & 0,862 & $(+) 1,39$ \\
Cumaru & 0,930 & 0,014 & 0,930 & $($ ) 0,00 \\
Ipê & 1,029 & 0,012 & 1,017 & $(+) 1,18$ \\
Sucupira & 1,115 & 0,017 & 1,111 & $(+) 0,36$ \\
\hline
\end{tabular}

As diferenças porcentuais entre as densidades das madeiras ensaiadas a U\% (teste do forno) e a $12 \%$ de umidade (equação de Brochard) foram: tão baixos que praticamente não interferiram nos valores das densidades aparentes, como será visto adiante.

\subsection{Determinações das densidades e coeficientes de absorção linear usando radiação gama}

Utilizando-se a equação (2), substituindo as intensidade I e Io pelas contagens $\mathrm{C}$ e Co e aplicando-se logaritmo neperiano aos dois membros da equação, obtêm-se os valores dos coeficientes de absorção linear das madeiras. Relacionando-se estes com o valor do coeficiente de absorção e densidade do padrão, o acrílico, obtiveram-se as densidades das madeiras. Os resultados estão apresentados nas TAB. 5 a 9. 
TABELA 5 - Densidades e coeficientes de absorção linear - ${ }^{241} \mathrm{Am}(59,5 \mathrm{keV})$

\begin{tabular}{llllc}
\hline $\begin{array}{l}\text { Madeira } \\
\text { Espécie })\end{array}$ & $\begin{array}{l}\text { Densidade a } \\
\mathrm{U} \%\left(\mathrm{~g} / \mathrm{cm}^{3}\right)\end{array}$ & $\begin{array}{l}\text { Densidade a } \\
12 \%\left(\mathrm{~g} / \mathrm{cm}^{3}\right)\end{array}$ & $\begin{array}{l}\text { Coeficiente } \\
\text { de absorção } \\
\text { linear }(\mu) \mathrm{a} \\
\mathrm{U} \%\left(\mathrm{~cm}^{-1}\right)\end{array}$ & $\begin{array}{c}\text { Coeficiente } \\
\text { de absorção } \\
\text { linear }(\mu) \mathrm{a} \\
12 \%\left(\mathrm{~cm}^{-1}\right)\end{array}$ \\
\hline Freijó & 0,599 & 0,596 & 0,10541 & 0,10482 \\
Peroba-mica & 0,707 & 0,700 & 0,12519 & 0,12501 \\
Jequitibá & 0,769 & 0,758 & 0,13401 & 0,13207 \\
Muiracatiara & 0,875 & 0,863 & 0,15532 & 0,15318 \\
Cumaru & 0,934 & 0,934 & 0,16398 & 0,16402 \\
Ipê & 1,051 & 1,039 & 0,18586 & 0,18381 \\
Sucupira & 1,117 & 1,113 & 0,19798 & 0,19723 \\
\hline
\end{tabular}

TABELA 6 - Densidades e coeficientes de absorção linear $-{ }^{133} \mathrm{Ba}(356 \mathrm{keV})$

\begin{tabular}{lllll}
\hline $\begin{array}{l}\text { Madeira } \\
\text { (Espécie) }\end{array}$ & $\begin{array}{l}\text { Densidade a } \\
\mathrm{U} \%\left(\mathrm{~g} / \mathrm{cm}^{3}\right)\end{array}$ & $\begin{array}{l}\text { Densidade a } \\
12 \%\left(\mathrm{~g} / \mathrm{cm}^{3)}\right.\end{array}$ & $\begin{array}{l}\text { Coeficiente } \\
\text { de absorção } \\
\text { linear }(\mu) \mathrm{a} \\
\mathrm{U} \%\left(\mathrm{~cm}^{-1}\right)\end{array}$ & $\begin{array}{l}\text { Coeficiente } \\
\text { de absorção } \\
\text { linear }(\mu) \mathrm{a} \\
12 \%\left(\mathrm{~cm}^{-1}\right)\end{array}$ \\
\hline Freijó & 0,577 & 0,574 & 0,05678 & 0,05646 \\
Peroba-mica & 0,693 & 0,692 & 0,06404 & 0,06394 \\
Jequitibá & 0,778 & 0,766 & 0,07608 & 0,07408 \\
Muiracatiara & 0,841 & 0,834 & 0,08395 & 0,08279 \\
Cumaru & 0,936 & 0,936 & 0,09153 & 0,09155 \\
Ipê & 1,030 & 1,019 & 0,10287 & 0,10173 \\
Sucupira & 1,118 & 1,114 & 0,10753 & 0,10717 \\
\hline
\end{tabular}


TABELA 7 - Densidades e coeficientes de absorção linear - ${ }^{182} \operatorname{Ir}(316 \mathrm{keV})$

\begin{tabular}{lccll}
\hline $\begin{array}{l}\text { Madeira } \\
\text { (Espécie) }\end{array}$ & $\begin{array}{l}\text { Densidade a } \\
\mathrm{U} \%\left(\mathrm{~g} / \mathrm{cm}^{3}\right)\end{array}$ & $\begin{array}{l}\text { Densidade a } \\
12 \%\left(\mathrm{~g} / \mathrm{cm}^{3}\right)\end{array}$ & $\begin{array}{l}\text { Coeficiente de } \\
\text { de absorção } \\
\text { linear }(\mu) \mathrm{a} \\
\mathrm{U} \%\left(\mathrm{~cm}^{-1}\right)\end{array}$ & $\begin{array}{l}\text { Coeficiente de } \\
\text { de absorção } \\
\text { linear }(\mu) \mathrm{a} \\
12 \%\left(\mathrm{~cm}^{-1}\right)\end{array}$ \\
\hline Freijó & 0,568 & 0,565 & 0,04333 & 0,04308 \\
Peroba-mica & 0,698 & 0,691 & 0,05032 & 0,04980 \\
Jequitibá & 0,748 & 0,737 & 0,05650 & 0,05568 \\
Muiracatiara & 0,859 & 0,847 & 0,06631 & 0,06540 \\
Cumaru & 0,923 & 0,923 & 0,07124 & 0,07125 \\
Ipê & 1,009 & 0,998 & 0,07744 & 0,07659 \\
Sucupira & 1,117 & 1,113 & 0,08456 & 0,08427 \\
\hline
\end{tabular}

TABELA 8 - Densidades e coeficientes de absorção linear $-{ }^{137}$ Cs $(662 \mathrm{keV})$

\begin{tabular}{lcccc}
\hline $\begin{array}{l}\text { Madeira } \\
\text { Espécie })\end{array}$ & $\begin{array}{c}\text { Densidade a } \\
\mathrm{U} \%\left(\mathrm{~g} / \mathrm{cm}^{3}\right)\end{array}$ & $\begin{array}{c}\text { Densidade a } \\
12 \%\left(\mathrm{~g} / \mathrm{cm}^{3}\right)\end{array}$ & $\begin{array}{l}\text { Coeficiente de } \\
\text { de absorção } \\
\text { linear( } \mu) \mathrm{a} \\
\mathrm{U} \%\left(\mathrm{~cm}^{-1}\right)\end{array}$ & $\begin{array}{l}\text { Coeficiente de } \\
\text { de absorção } \\
\text { linear }(\mu) \mathrm{a} \\
12 \%\left(\mathrm{~cm}^{1}\right)\end{array}$ \\
\hline Freijó & 0,583 & 0,580 & 0,04518 & 0,04492 \\
Peroba-mica & 0,698 & 0,691 & 0,05398 & 0,05342 \\
Jequitibá & 0,759 & 0,748 & 0,05886 & 0,05801 \\
Muiracatiara & 0,872 & 0,860 & 0,06753 & 0,06660 \\
Cumaru & 0,913 & 0,913 & 0,07251 & 0,07253 \\
Ipê & 0,996 & 0,996 & 0,08039 & 0,07950 \\
\hline Sucupira & 1,128 & 1,124 & 0,08748 & 0,08718 \\
\hline
\end{tabular}


TABELA 9 - Densidades e coeficientes de absorção linear $-{ }^{60} \mathrm{Co}(1.170 \mathrm{keV})$

\begin{tabular}{lcccc}
\hline $\begin{array}{l}\text { Madeira } \\
\text { (Espécie) }\end{array}$ & $\begin{array}{c}\text { Densidade a } \\
\mathrm{U} \%\left(\mathrm{~g} / \mathrm{cm}^{3}\right)\end{array}$ & $\begin{array}{c}\text { Densidade a } \\
12 \%\left(\mathrm{~g} / \mathrm{cm}^{3}\right)\end{array}$ & $\begin{array}{l}\text { Coeficiente de } \\
\text { de absorção } \\
\text { linear }(\mu) \mathrm{a} \\
\mathrm{U} \%\left(\mathrm{~cm}^{-1}\right)\end{array}$ & $\begin{array}{l}\text { Coeficiente de } \\
\text { de abso rção } \\
\text { linear }(\mu) \mathrm{a} \\
12 \%\left(\mathrm{~cm}^{-1}\right)\end{array}$ \\
\hline Freijó & 0,595 & 0,592 & 0,02612 & 0,02597 \\
Peroba-mica & 0,707 & 0,699 & 0,03729 & 0,03690 \\
Jequitibá & 0,742 & 0,731 & 0,03915 & 0,03858 \\
Muiracatiara & 0,858 & 0,846 & 0,04524 & 0,04462 \\
Cumaru & 0,909 & 0,909 & 0,04791 & 0,044792 \\
Ipê & 0,995 & 0,984 & 0,05295 & 0,055237 \\
Sucupira & 1,112 & 1,109 & 0,05879 & 0,05859 \\
\hline
\end{tabular}

Para comparação, os valores encontrados nos ensaios realizados com radiação gama: ${ }^{241} \mathrm{Am},{ }^{133} \mathrm{Ba},{ }^{192} \mathrm{Ir},{ }^{137} \mathrm{Cs}$ e ${ }^{60} \mathrm{Co}$, estão apresentados na TAB. 10 , juntamente com as densidades obtidas pelo método convencional.

TABELA 10 - Comparação das densidades a 12\% obtidas pelos dois métodos

\begin{tabular}{lcccccc}
\hline $\begin{array}{l}\text { Madeira } \\
\text { (Espécie) }\end{array}$ & $\begin{array}{l}\text { Densidade } \\
\text { convencio } \\
\text { nal }\left(\mathrm{g} / \mathrm{cm}^{3}\right)\end{array}$ & $\begin{array}{l}\text { Densidade } \\
\left(\begin{array}{l}\left.{ }^{241} \mathrm{Am}\right) \\
\left(\mathrm{g} / \mathrm{cm}^{3}\right)\end{array}\right.\end{array}$ & $\begin{array}{l}\text { Densidade } \\
\left({ }^{133} \mathrm{Ba}\right) \\
\left(\mathrm{g} / \mathrm{cm}^{3}\right)\end{array}$ & $\begin{array}{l}\text { Densidade } \\
\left({ }^{192} \mathrm{Ir}\right) \\
\left(\mathrm{g} / \mathrm{cm}^{3}\right)\end{array}$ & $\begin{array}{l}\text { Densidade } \\
\left({ }^{137} \mathrm{Cs}\right) \\
\left(\mathrm{g} / \mathrm{cm}^{3}\right)\end{array}$ & $\begin{array}{l}\text { Densidade } \\
\left({ }^{60} \mathrm{Co}\right) \\
\left(\mathrm{g} / \mathrm{cm}^{3}\right)\end{array}$ \\
\hline Freijó & 0,578 & 0,596 & 0,574 & 0,565 & 0,580 & 0,592 \\
$\begin{array}{l}\text { Peroba- } \\
\text { mica }\end{array}$ & 0,691 & 0,700 & 0,692 & 0,691 & 0,691 & 0,699 \\
$\begin{array}{l}\text { Jequitibá } \\
\text { Muiraca }\end{array}$ & 0,749 & 0,758 & 0,766 & 0,737 & 0,748 & 0,731 \\
tiara & 0,862 & 0,863 & 0,834 & 0,847 & 0,860 & 0,846 \\
Cumaru & 0,930 & 0,934 & 0,936 & 0,923 & 0,913 & 0,909 \\
Ipê & 1,017 & 1,039 & 1,019 & 0,998 & 0,996 & 0,984 \\
Sucupira & 1,111 & 1,113 & 1,114 & 1,113 & 1,124 & 1,109 \\
\hline
\end{tabular}


Na TAB.11 é mostrada a comparação percentual, entre os valores médios das densidades obtidas com a técnica convencional e a nuclear.

TABELA 11 - Comparação das densidades médias pelos dois métodos (por espécie)

\begin{tabular}{lcccc}
\hline $\begin{array}{l}\text { Madeira } \\
\text { (Espécie) }\end{array}$ & $\begin{array}{c}\text { Método nuclear } \\
\text { Densidade } \\
\text { média }\left(\mathrm{g} / \mathrm{cm}^{3}\right)\end{array}$ & $\begin{array}{c}\text { Desvio } \\
\text { padrão }\end{array}$ & $\begin{array}{c}\text { Método } \\
\text { convencional } \\
\text { Densidade } \\
\text { média }\left(\mathrm{g} / \mathrm{cm}^{3}\right)\end{array}$ & $\begin{array}{c}\text { Diferença } \\
\text { percentual } \\
\text { Dc/Dn } \\
(\%)\end{array}$ \\
\hline Freijó & 0,581 & 0,00127 & 0,578 & $(-) 0,52$ \\
Peroba-mica & 0,695 & 0,00450 & 0,691 & $(-) 0,58$ \\
Jequitibá & 0,748 & 0,01440 & 0,749 & $(+) 0,13$ \\
Muiracatiara & 0,850 & 0,01172 & 0,862 & $(+) 1,39$ \\
Cumaru & 0,923 & 0,02542 & 0,930 & $(+) 0,75$ \\
Ipê & 1,007 & 0,00127 & 1,017 & $(+) 0,98$ \\
Sucupira & 1,115 & 0,00594 & 1,111 & $(-) 0,36$ \\
\hline $\begin{array}{l}\text { Dc = densidade média pelo método convencional; } \\
\text { Dn = densidade média pelo método nuclear. }\end{array}$ & &
\end{tabular}

Na TAB. 12 são apresentadas as relações entre os coeficientes de absorção linear e as densidades das diferentes espécies de madeira.

TABELA 12 - Relação entre coeficientes de absorção linear e densidades

\begin{tabular}{lcllll}
\hline $\begin{array}{l}\text { Madeira } \\
\text { Espécie })\end{array}$ & ${ }^{241} \mathrm{Am}$ & $\begin{array}{c}{ }^{133} \mathrm{Ba} \\
(\mu / \rho)\end{array}$ & $\begin{array}{l}{ }^{192} \mathrm{Ir} \\
(\mu / \rho)\end{array}$ & $\begin{array}{l}{ }^{137} \mathrm{Cs} \\
(\mu / \rho)\end{array}$ & $\begin{array}{l}{ }^{60} \mathrm{Co} \\
(\mu / \rho)\end{array}$ \\
\hline Freijó & 0,17687 & 0,09836 & 0,07625 & 0,07745 & 0,05282 \\
Peroba-mica & 0,17682 & 0,10022 & 0,07650 & 0,07731 & 0,05274 \\
Jequitibá & 0,17423 & 0,09671 & 0,07555 & 0,07755 & 0,05366 \\
Muiracatiara & 0,17749 & 0,09987 & 0,07721 & 0,07744 & 0,05272 \\
Cumaru & 0,17561 & 0,09781 & 0,07719 & 0,07944 & 0,05367 \\
Ipê & 0,17691 & 0,09983 & 0,07674 & 0,08071 & 0,05211 \\
Sucupira & 0,17721 & 0,09620 & 0,07571 & 0,07756 & 0,05287 \\
Média $(\mu / \rho)$ & 0,17645 & 0,09843 & 0,07641 & 0,07821 & 0,05282 \\
Desvio padrão & 0,00141 & 0,00161 & 0,00066 & 0,00133 & 0,00055 \\
\hline
\end{tabular}


A relação $\mu / \rho$, coeficiente de absorção linear dividido pela densidade, nada mais é do que o coeficiente de absorção de massa, um parâmetro que independe da densidade e da espessura do material, dependendo somente da energia do radioisótopo. Mostra pelos pequenos desvios padrões calculados, a excelência do método.

\subsection{Determinações das meias espessuras}

Para a obtenção dos valores das meias espessuras, foi utilizada a equação de Lambert-Beer (2), e o conceito de meia-espessura, isto é, considerando a intensidade do feixe após a atenuação no material igual à metade do feixe de radiação gama inicial (incidente). Assim a equação de Lambert-Beer, após a substituição de I = Io/2 em (2) e aplicado aos dois membros, logaritmo neperiano, tem-se:

$$
X_{1 / 2}=0,69314 / \mu
$$

em que:

$\mathrm{x}_{1 / 2}$ é o valor da meia-espessura $(\mathrm{cm})$;

$\mu$ é o coeficiente de absorção linear $\left(\mathrm{cm}^{-1}\right)$ já tabelados anteriormente.

Calculando, têm-se os seguintes resultados apresentados na TAB. 13.

TABELA 13 - Meias espessuras das madeiras em mm, em função das energias dos emissores gama

\begin{tabular}{lccccc}
\hline $\begin{array}{l}\text { Madeira } \\
\text { (Espécie) }\end{array}$ & ${ }^{241} \mathrm{Am}$ & ${ }^{133} \mathrm{Ba}$ & ${ }^{192} \mathrm{Ir}$ & ${ }^{137} \mathrm{Cs}$ & ${ }^{60} \mathrm{Co}$ \\
\hline Freijó & 66,1 & 122,8 & 160,9 & 154,3 & 266,9 \\
Peroba-mica & 55,4 & 108,4 & 139,2 & 129,8 & 187,8 \\
Jequitibá & 52,5 & 93,6 & 124,5 & 119,5 & 179,7 \\
Muiracatiara & 45,1 & 83,7 & 106,0 & 104,1 & 155,3 \\
Cumaru & 42,3 & 75,7 & 97,3 & 95,6 & 144,6 \\
Ipê & 37,7 & 68,1 & 90,5 & 87,2 & 132,2 \\
\hline Sucupira & 35,1 & 64,7 & 82,3 & 79,5 & 118,3 \\
\hline
\end{tabular}


Esses valores a princípio podem ser tomados como referência para testes com outras madeiras e outras espessuras.

Graficamente esses valores podem ser obtidos segundo os gráficos das FIG. 16 a 20.

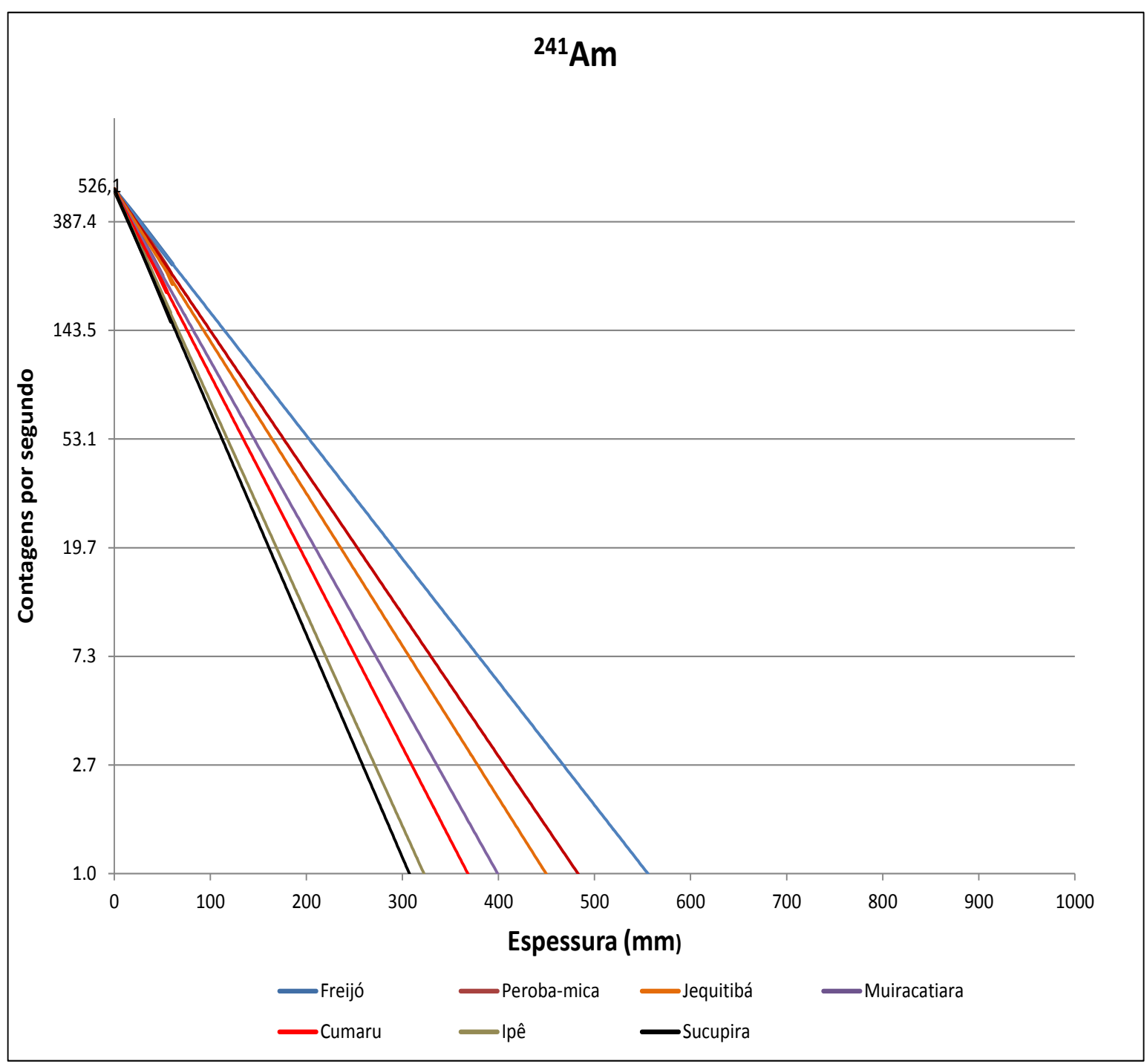

FIGURA 16 - Coeficientes de absorção linear obtidos com ${ }^{241} \mathrm{Am}-59,5 \mathrm{keV}$ 


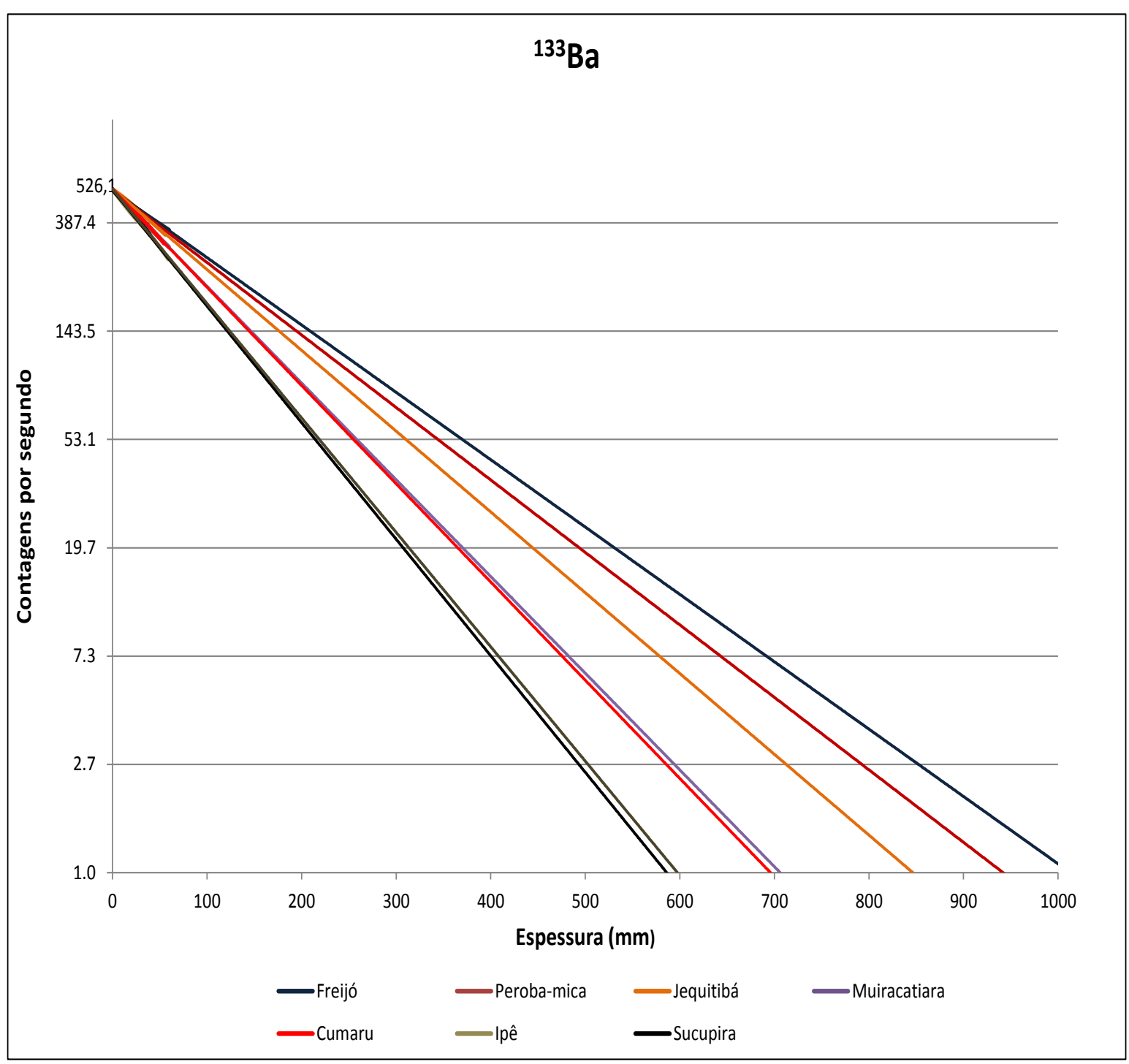

FIGURA 17 - Coeficientes de absorção linear obtidos com ${ }^{133} \mathrm{Ba}-356 \mathrm{keV}$ 


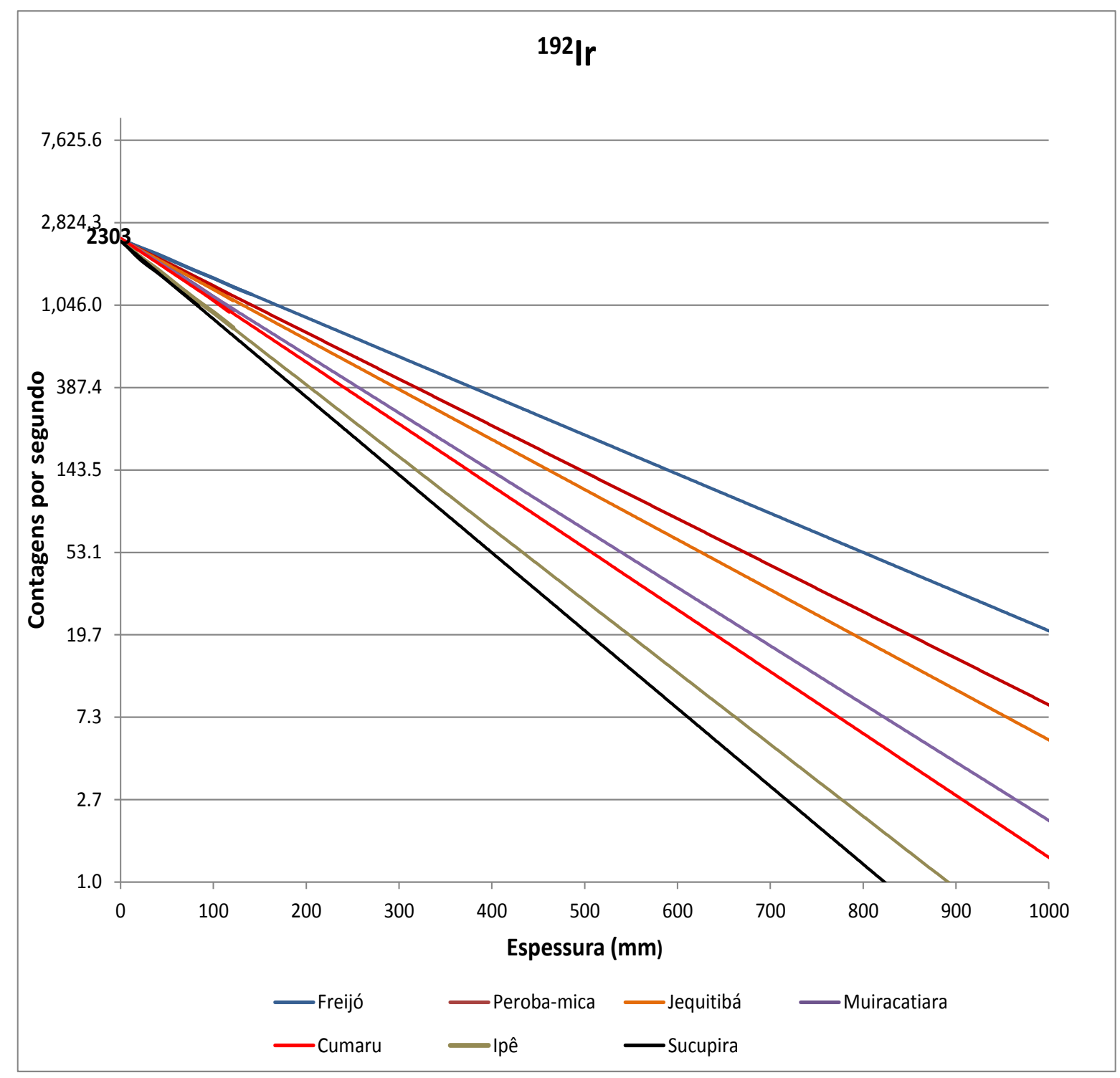

FIGURA 18 - Coeficientes de absorção linear obtidos com ${ }^{192} \mathrm{Ir}-316 \mathrm{keV}$ 


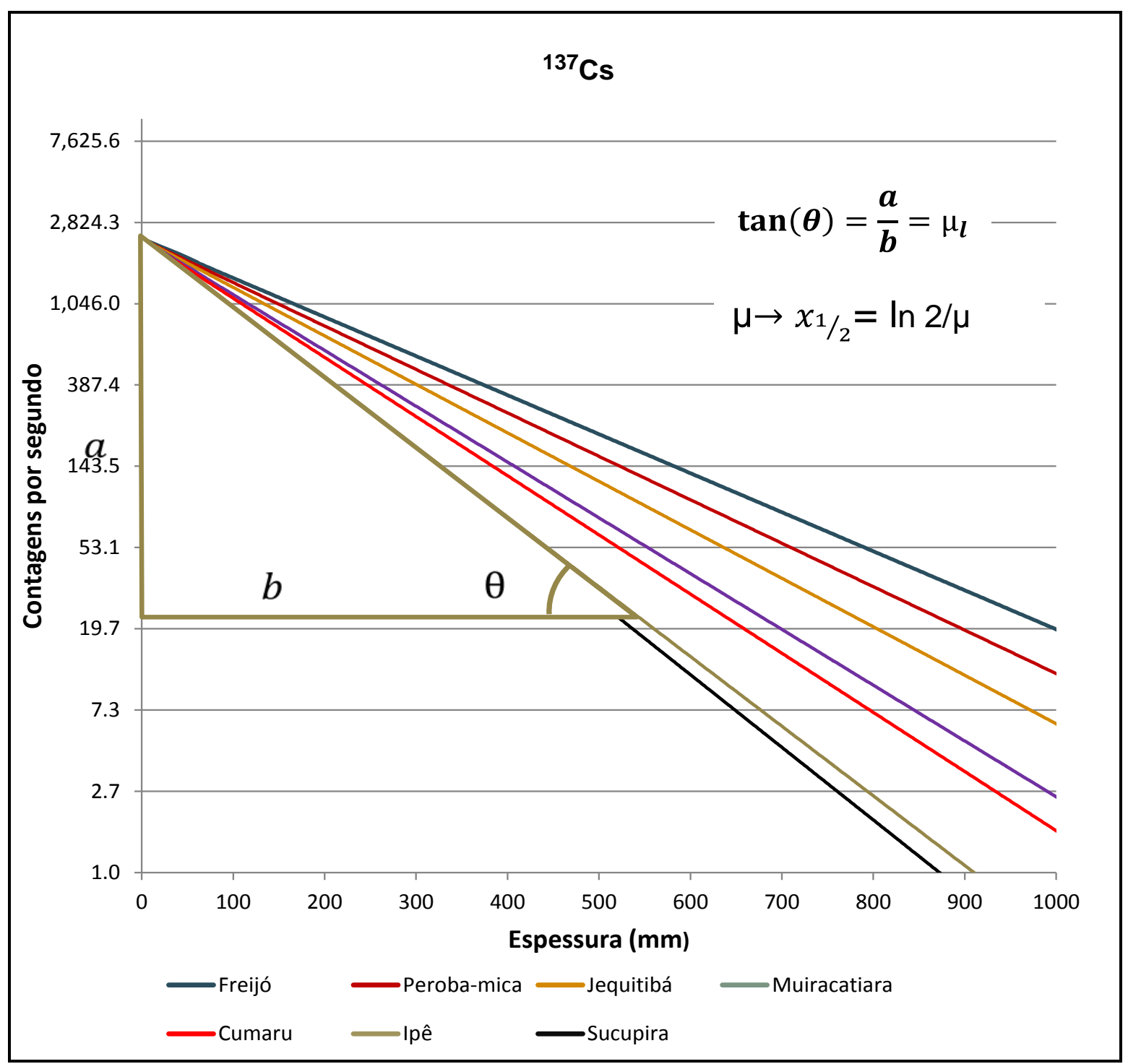

FIGURA 19 - Coeficientes de absorção linear obtidos com ${ }^{137} \mathrm{Cs}-662 \mathrm{keV}$ 


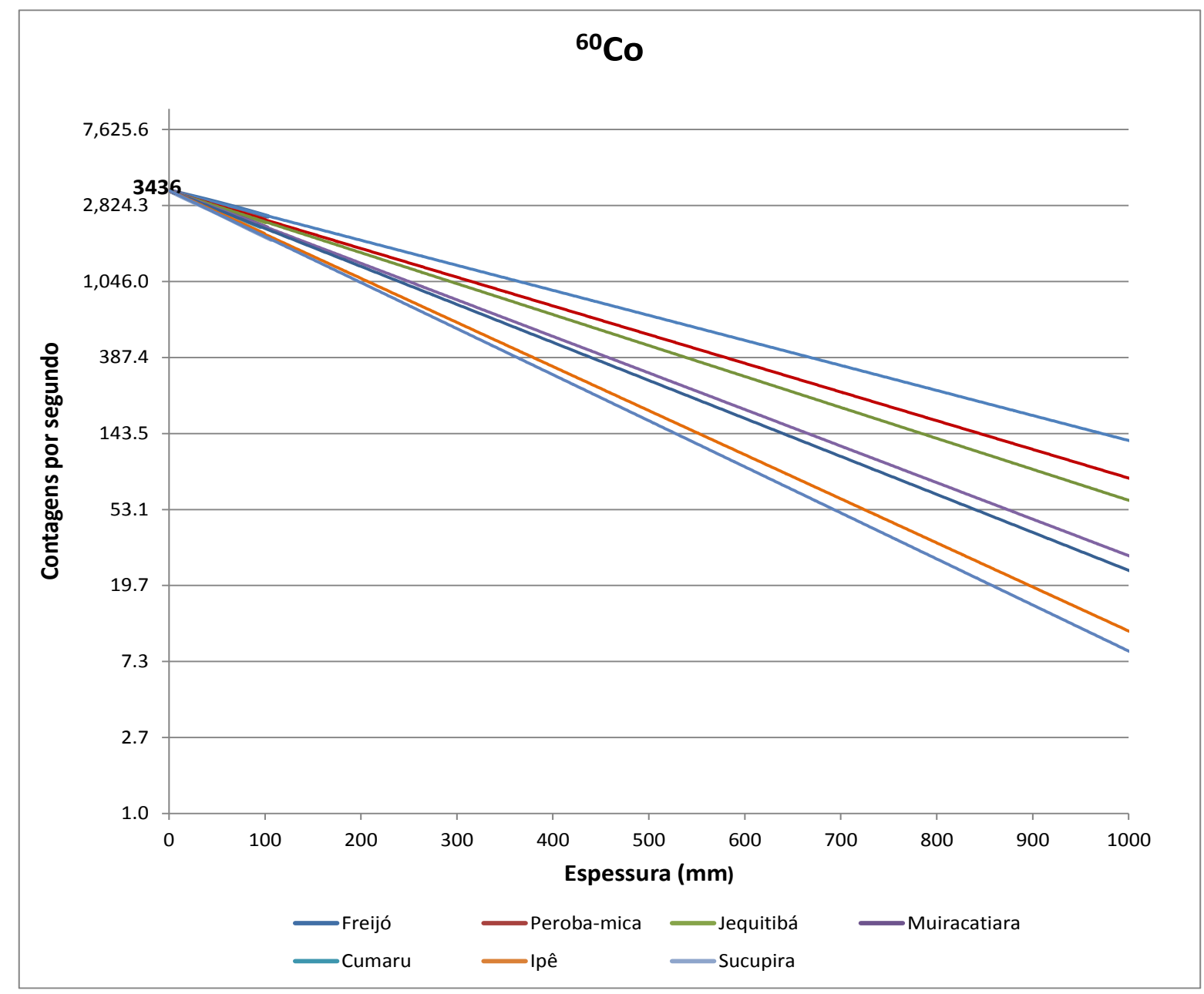

FIGURA 20 - Coeficientes de absorção linear obtidos com ${ }^{60} \mathrm{Co}-1.170 \mathrm{keV}$

Observando-se os gráficos das FIG. 16 a 20, pode-se observar que:

a - Os radioisótopos que melhor discriminam as densidades (separação melhor) são: ${ }^{241} \mathrm{Am}$, ${ }^{192}$ Ir e ${ }^{137} \mathrm{Cs}$;

$\mathrm{b}-\mathrm{O}{ }^{133} \mathrm{Ba} \mathrm{e}{ }^{60} \mathrm{Co}$ somente discriminam as madeiras de baixa e média densidades;

c - Como era esperado, as fontes radioativas com maiores energias, como ${ }^{137} \mathrm{Cs}$ e ${ }^{60} \mathrm{Co}$, possibilitam ensaios de madeiras com espessuras maiores;

d - As FIG. 16 a 20 são bastante ilustrativas, permitindo visualizar rapidamente as espessuras que se pode ensaiar de cada espécie de madeira;

e - Apesar da boa discriminação das densidades, o ${ }^{192}$ Ir apresenta a desvantagem de ter meia vida curta, necessitando constante correção da atividade e por conseguinte, troca de fontes com atividades mais altas;

f - A visualização do coeficiente de absorção linear, tomado o ipê e o ${ }^{137}$ Cs como exemplo, torna o conceito menos abstrato $(\operatorname{tg} \Theta=a / b)$. 
A discussão sobre fontes radioativas permite que se enumere as vantagens da utilização do ${ }^{137} \mathrm{Cs}$, para as simulações mostradas a seguir e para futuros trabalhos:

a - Alta energia, permitindo ensaios de grandes espessuras;

b - Fabricação no CTR (Centro de Tecnologia das Radiações), possibilitando a rapidez de obtenção e variedade de atividades;

c- Praticamente monoenergética;

d - É o radioisótopo mais compatível com o detetor de NaI de 2" (Ludlum);

e - Meia vida alta (30,14 anos), não necessitando de correções;

f - Apresenta boa discriminação de densidades, como pode ser visto na FIG. 19.

\subsection{Simulação em laboratório de teste de integridade de postes de eucalipto utilizando a madeira Ipê}

A distribuição de energia elétrica depende de estrutura de suporte, como postes, os quais podem utilizar a madeira como material básico. É recomendado que esse material tivesse durabilidade suficiente, de maneira que as qualidades e características originais sejam preservadas durante o seu uso. A madeira de reflorestamento, e em especial, o eucalipto, é uma alternativa competitiva para a distribuição de energia, especialmente nas áreas rurais. O eucalipto citriodora (Eucalyptus citriodora, Hook) pertence à família das Mirtáceas, e é uma das muitas espécies usadas no país, sendo originário da Austrália, mas se adaptando bem ao clima brasileiro, foi plantado em várias regiões do Brasil, como no estado de São Paulo, Minas Gerais e Bahia. Essa madeira tem alta resistência mecânica, durabilidade natural, pouca tendência ao rachamento e possui densidade aparente a $12 \%$, de $1,012 \mathrm{~g} / \mathrm{cm}^{3}$.

Tendo em vista o extenso uso dos postes de madeira nas áreas rurais, principalmente nas regiões sul (cerca de $90 \%$ do total de postes instalados), sudeste e centro-oeste, e as implicações na vida pessoal e econômica dos habitantes dessas regiões, foi realizada uma simulação em laboratório, com corpos de prova de ipê, com densidade aparente a $12 \%$ de $0,996 \mathrm{~g} / \mathrm{cm}^{3}$, valor muito próximo do eucalipto citriodora, na tentativa de incluir um ensaio não destrutivo, na inspeção de postes de até $25 \mathrm{~cm}$ de diâmetro, podendo essa inspeção estender-se a cruzetas e dormentes. A seguir, a título de ilustração, na FIG. 21 (ARRUDA, 2006) é mostrado um esquema de um poste, cujo engastamento depende de sua altura e de seu diâmetro. 


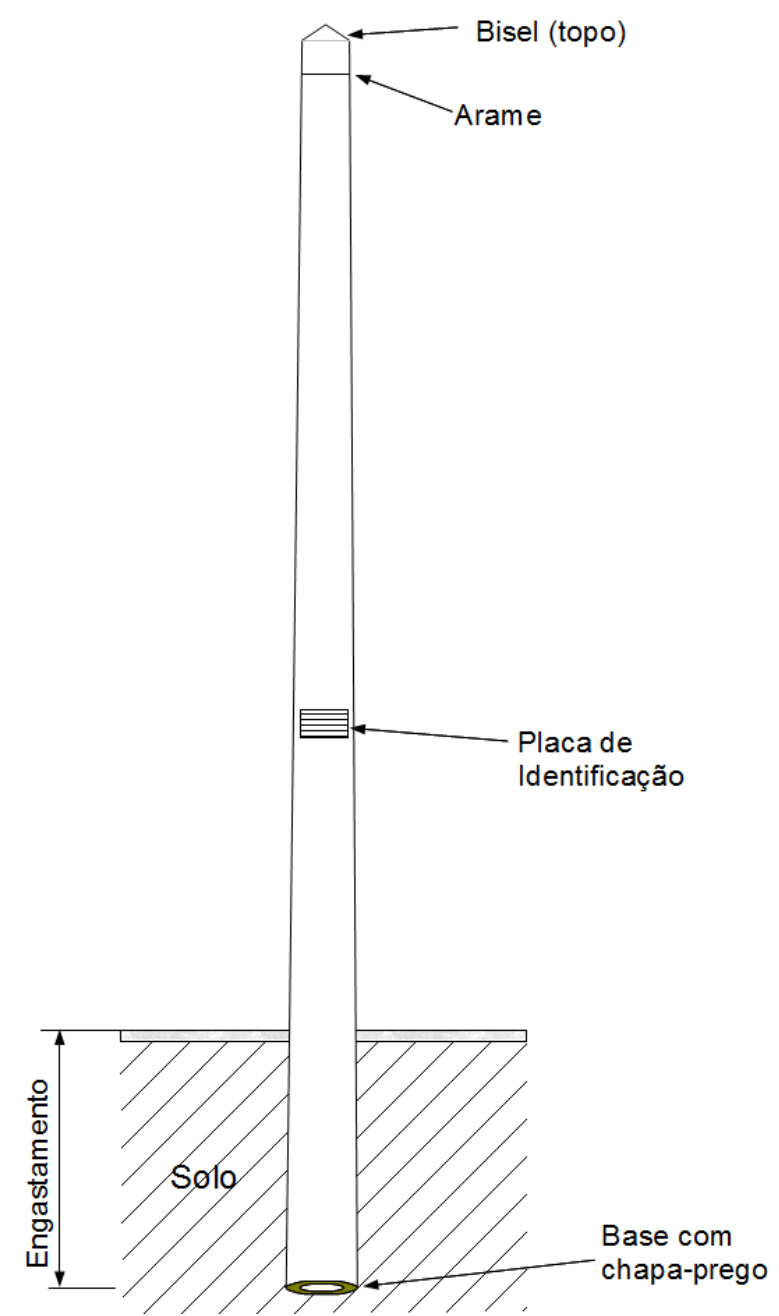

FIGURA 21 - Esquema de um poste usado no Rio Grande do Sul, pela distribuidora AESSul.

O gráfico mostrado na FIG. 22 foi elaborado a partir dos dados obtidos com ${ }^{137} \mathrm{Cs}$ (contagens x espessuras). Os parâmetros usados foram: $C_{o}($ contagem sem material $)=1424$ $\mathrm{c} / \mathrm{s} ; \mathrm{C}_{\mathrm{acr} .}($ contagem do padrão de acrílico $)=1200 \mathrm{c} / \mathrm{s} ; \mu_{\mathrm{acr}}=0,08934 \mathrm{~cm}^{-1}$, distância fontedetetor $=315 \mathrm{~mm}$.

Foram ensaiados quatorze corpos de prova separadamente e determinadas suas densidades aparentes para verificação da uniformidade dos mesmos. A densidade média resultou em $0,996 \mathrm{~g} / \mathrm{cm}^{3}$, valor muito próximo de $1,012 \mathrm{~g} / \mathrm{cm}^{3}$, justificando o uso das amostras de ipê para a simulação.

Posteriormente os corpos de prova foram agrupados, com espessuras diferentes, iniciando-se com todos os corpos de prova disponíveis (para o traçado da curva do ipê), dando um valor de espessura de $25 \mathrm{~mm}$ e 194 contagens/segundo e densidade aparente de $1,00 \mathrm{~g} / \mathrm{cm}^{3}$. Em sequência foram retirados gradualmente os corpos-de-prova, formando 
novos conjuntos e medidos. Os resultados dos ensaios em postes com madeira ipê e fonte de ${ }^{137}$ Cs, estão apresentados na TAB. 14.

TABELA 14 - Simulação de ensaios em postes com madeira ipê e fonte de ${ }^{137}$ Cs.

\begin{tabular}{ccccc}
\hline $\begin{array}{c}\text { Espessuras de } \\
\text { ensaio } \\
(\mathrm{mm})\end{array}$ & $\begin{array}{c}\text { Vazio } \\
\text { simulado } \\
(\mathrm{mm})\end{array}$ & $\begin{array}{c}\text { Porcentual da } \\
\text { espessura total } \\
(\%)\end{array}$ & $\begin{array}{c}\text { Contagens/ } \\
\text { segundo } \\
(\mathrm{c} / \mathrm{s})\end{array}$ & $\begin{array}{c}\text { Diferença de } \\
\text { contagens } \\
(\mathrm{c} / \mathrm{s})\end{array}$ \\
\hline 250,0 & 0,0 & 0,0 & 194 & 0,0 \\
233,5 & 16,5 & 6,6 & 219 & 25 \\
229,4 & 20,6 & 8,2 & 227 & 33 \\
216,3 & 33,7 & 13,5 & 253 & 59 \\
197,0 & 53,0 & 21,4 & 290 & 96 \\
\hline
\end{tabular}

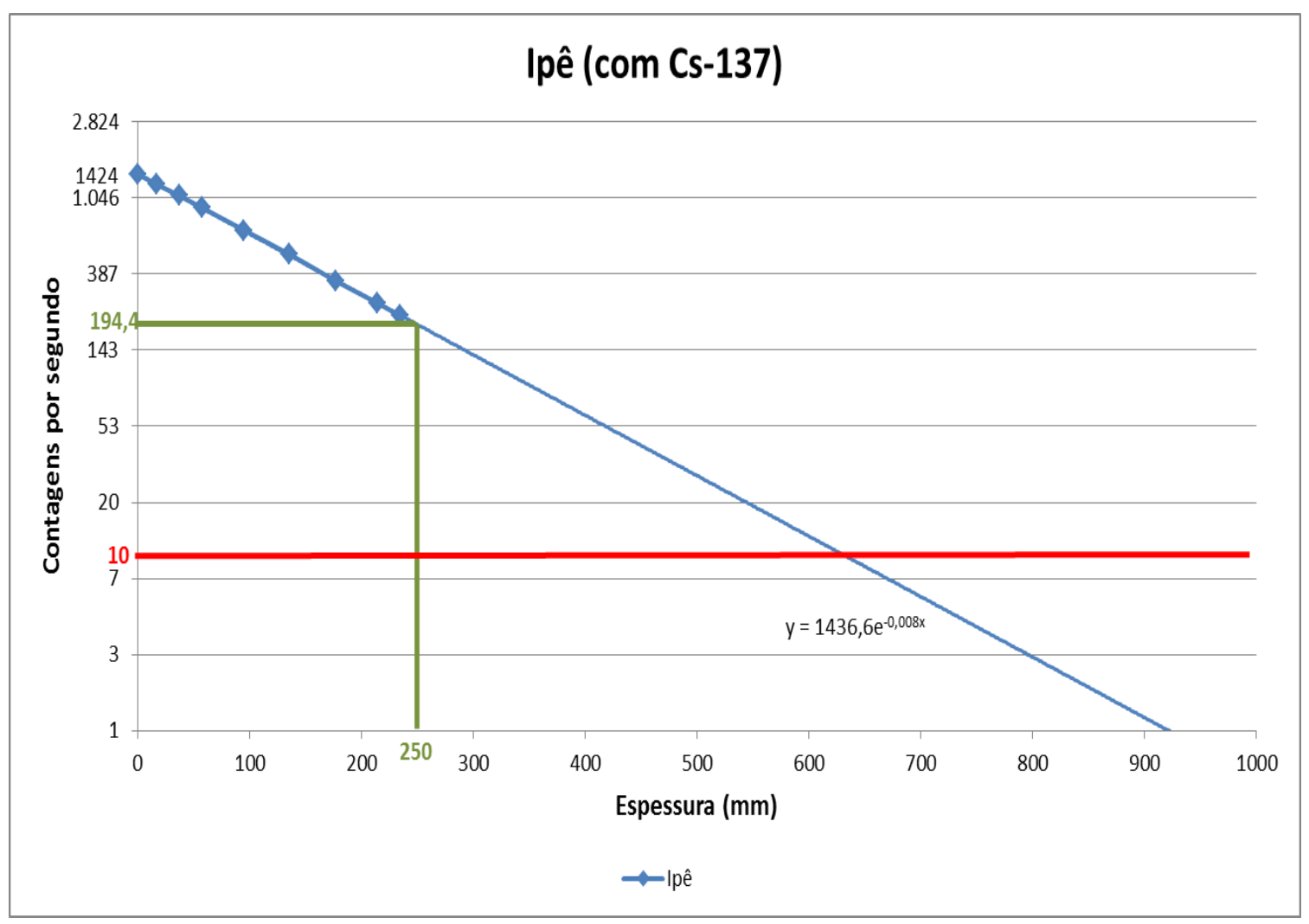

FIGURA 22 - Gráfico para simulação de ensaios em postes $\left({ }^{137} \mathrm{Cs}\right)$

Na FIG.22, observa-se duas marcações, uma em vermelho, que indica o valor de 10 (dez vezes), o BG ou radiação de fundo e que foi tomado como contagem limite. $\mathrm{O}$ valor 
do BG, em torno de 1,0 c/s, foi medido em laboratório com o mesmo espectrômetro usado nos ensaios das madeiras. A outra marcação, em verde, indica que para um poste de $250 \mathrm{~mm}$ de diâmetro, o valor das contagens foi de $94 \mathrm{c} / \mathrm{s}$.

\subsection{Simulação em laboratório de teste de integridade de árvores vivas, com a madeira sucupira}

Para uso em laboratório e especialmente no campo, foi construído nas oficinas do IPEN, um protótipo, mostrado na FIG. 12, em alumínio, em duas partes iguais. Em uma delas é fixada a fonte radioativa, blindada e colimada e na outra parte, um suporte em $\mathrm{V}$ para o detetor de $\mathrm{NaI}$, de tal forma que fiquem em posições diametralmente opostas e alinhados, feixe e detetor. As duas metades são unidas e fixadas mediante o uso de duas hastes com roscas. Esse dispositivo foi projetado para medidas de espessuras ou diâmetros, a partir de $225 \mathrm{~mm}$.

A medição dos diâmetros das árvores com régua e mais especificamente com trena, é possível, bastando fazer a leitura da circunferência na altura que se deseja ensaiar, porém ambos são métodos bastante imprecisos. Para a avaliação mais precisa do diâmetro das árvores, optou-se pela construção de um paquímetro chamado de dendrológico, justamente pela função à qual se destina, para medidas de troncos de madeira morta e viva.

Foi construído na oficina mecânica do IPEN, em alumínio (estrutura e cursor) e tem uma escala graduada (régua de plástico), com divisões de $1 \mathrm{~mm}$, pesa cerca de $1,5 \mathrm{~kg}$ e possibilita ensaios em troncos de até 500mm (FIG. 23).

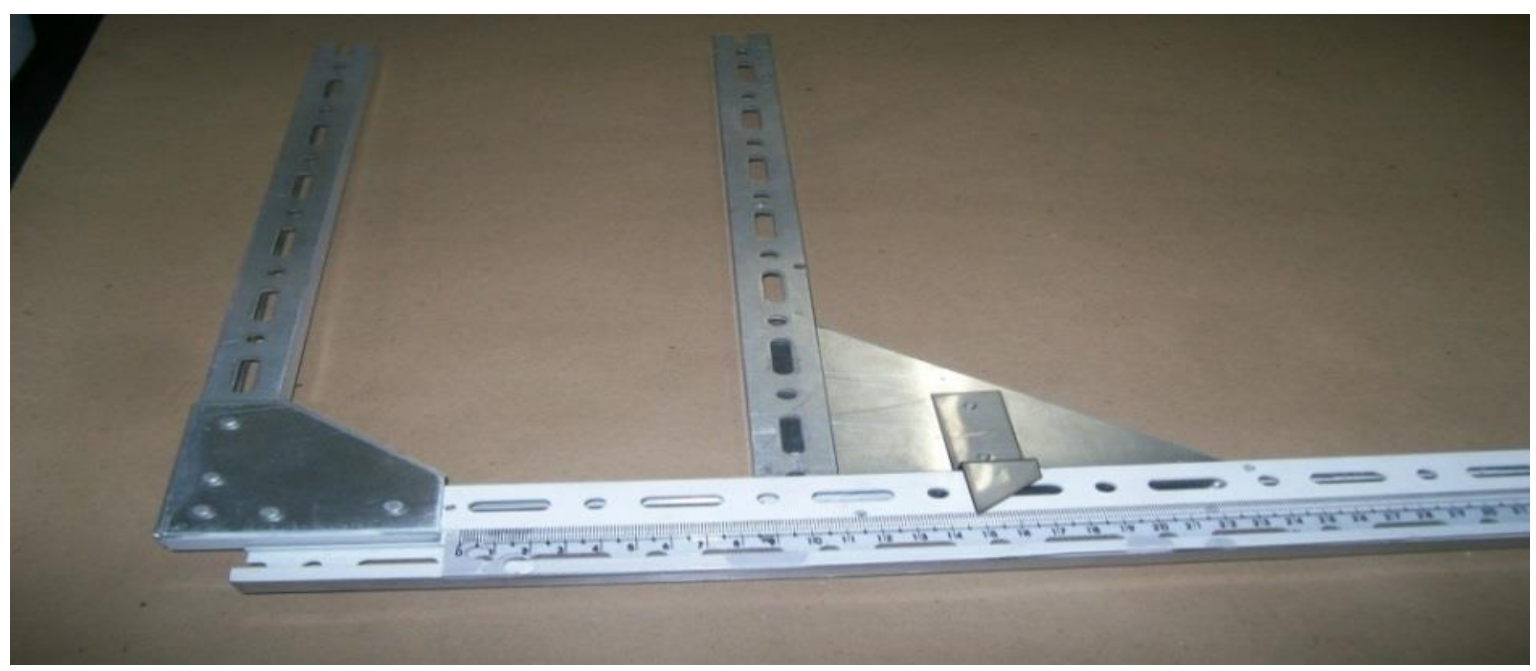

FIGURA 23 - Paquímetro dendrológico 
Foram ensaiados dezesseis corpos de prova separadamente (individualmente) e determinadas suas densidades aparentes, para verificação da uniformidade dos mesmos e a média das densidades resultou em $1,11 \mathrm{~g} / \mathrm{cm}^{3}$.

Os corpos de prova foram mergulhados em água destilada por 48 horas, quando foram novamente medidos, para verificação da uniformidade de densidades, conseguindose um o valor para a densidade de $1,19 \mathrm{~g} / \mathrm{cm}^{3}$, tomada com referência de densidade a verde (a literatura fornece valores díspares, de $1,22 \mathrm{~g} / \mathrm{cm}^{3}$ a $1,31 \mathrm{~g} / \mathrm{cm}^{3}$ ).

Posteriormente os corpos de prova foram agrupados, iniciando-se o ensaio com todos os corpos disponíveis, totalizando $327 \mathrm{~mm}$ de espessura e obtendo-se 44 contagens/segundo. Em sequência foram retirados gradualmente os corpos de prova, formando novos conjuntos e novas medidas. A média da densidade desses conjuntos resultou em $1,18 \mathrm{~g} / \mathrm{cm}^{3}$, qualificando os corpos de prova, para simulação. A plotagem desses valores resultou no gráfico da FIG. 24.

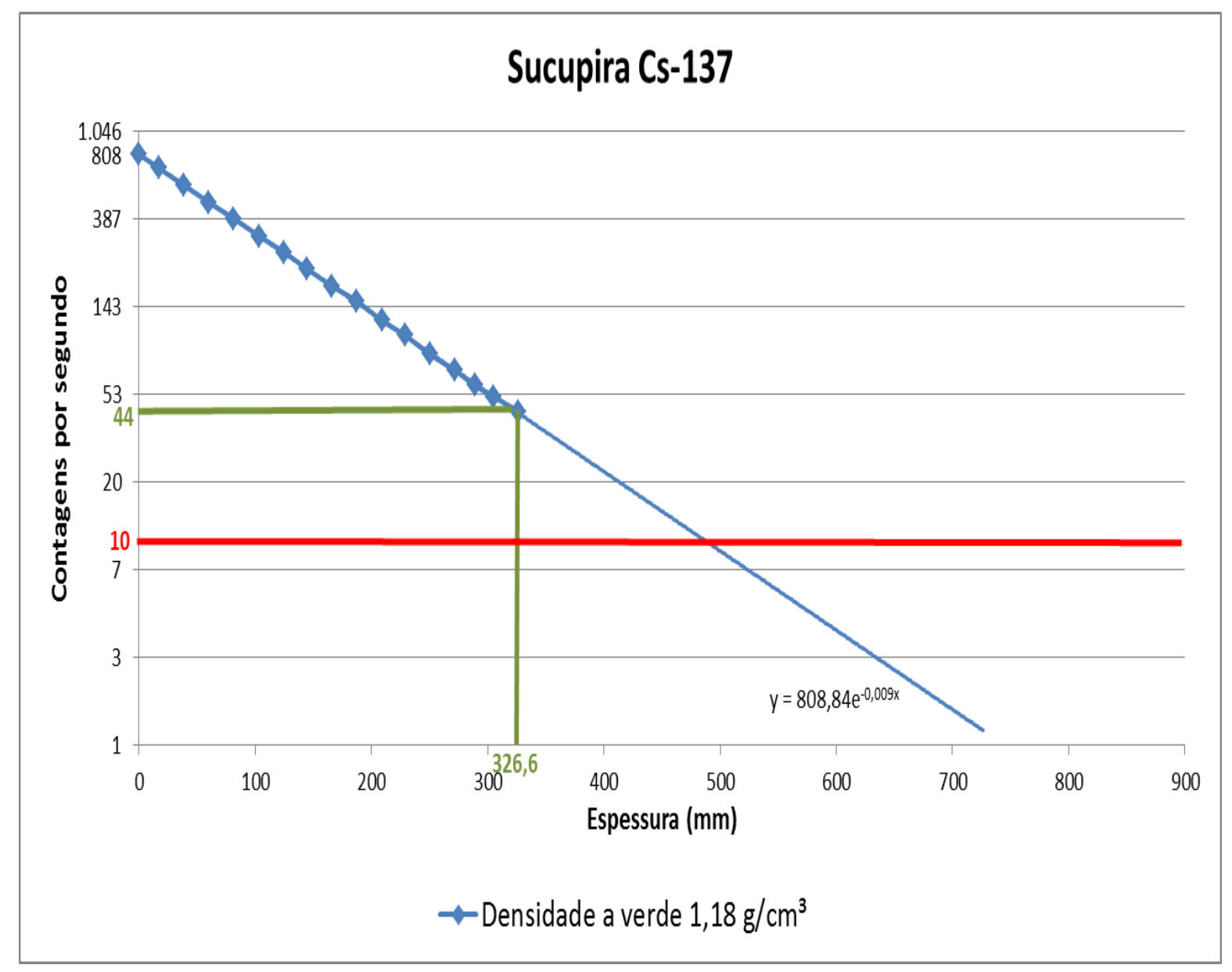

FIGURA 24 - Gráfico para simulação de ensaios em árvores em pé ( $\left.{ }^{137} \mathrm{Cs}\right)$ 
Os parâmetros do ensaio foram: $\mathrm{C}_{\mathrm{o}}$ (contagem sem material) $=808 \mathrm{c} / \mathrm{s} ; \mathrm{C}_{\mathrm{acr}}$. $($ contagem do padrão de acrílico $)=681 \mathrm{c} / \mathrm{s} ; \mu_{\mathrm{acr}}=0,08950 \mathrm{~cm}^{-1}$, distância fonte-detetor $=$ 390mm. Os valores resultantes dos ensaios estão listados na TAB. 15.

TABELA 15 - Simulação de ensaios em árvores vivas com madeira de sucupira e fonte de ${ }^{137} \mathrm{Cs}$

\begin{tabular}{ccccc}
\hline $\begin{array}{c}\text { Espessura } \\
\text { de ensaio } \\
(\mathrm{mm})\end{array}$ & $\begin{array}{c}\text { Vazio } \\
\text { simulado } \\
(\mathrm{mm})\end{array}$ & $\begin{array}{c}\text { Porcentual da } \\
\text { espessura total } \\
(\%)\end{array}$ & $\begin{array}{c}\text { Contagens/ } \\
\text { Segundo } \\
(\mathrm{C} / \mathrm{s})\end{array}$ & $\begin{array}{c}\text { Diferença de } \\
\text { contagens } \\
(\mathrm{C} / \mathrm{s})\end{array}$ \\
\hline 327,0 & 0,0 & 0,0 & 44 & 0,0 \\
305,6 & 21,4 & 6,5 & 54 & 10 \\
289,6 & 37,4 & 11,4 & 69 & 25 \\
272,2 & 54,8 & 16,8 & 77 & 33 \\
250,8 & 76,2 & 23,3 & 84 & 40 \\
229,4 & 97,6 & 29,8 & 104 & 60 \\
\hline
\end{tabular}

Deve-se ressaltar que além da técnica da avaliação de postes, cruzetas, dormentes e árvores vivas com atenuação da radiação gama, mediante contagens, há vários outros métodos, destrutivos e não destrutivos, tais como: inspeção visual; sondagem e percussão; trado de incremento e formão; ondas de tensão; perfuração controlada (pilodyn e resistógrafo) (ABREU, 2010), além de técnicas mais sofisticadas como micro-ondas, ultrassom, técnica térmica, NMR (Ressonância magnética nuclear), com alta resolução de imagens (BUCUR, 2003) e mesmo atenuação gama, mediante registro em filmes (gamagrafia) (SANCHEZ, 1974). 


\section{CONCLUSÕES}

Pode-se dividir as conclusões em partes, em conformidade com os resultados obtidos nas várias etapas estudadas:

\section{a -Testes do forno}

Os resultados de umidade obtidos pelo método do forno, praticamente todos próximos do teor de umidade de $12 \%$, mostraram que os testes foram conduzidos corretamente, pois os desvios padrões foram muito pequenos.

\section{b - Coeficientes de absorção linear}

Não se encontra na literatura, dados que pudessem balizar os resultados encontrados neste trabalho. Os valores encontrados nos ensaios e que permitiram o cálculo das densidades, em comparação com o padrão acrílico, levou-se a concluir que são muito bons, haja vista, os valores das densidades obtidas. Os valores calculados de $(\mu / \rho)$, apresentaram valores muitos baixos dos desvios padrões, o que valida mais os dados. Esses valores a princípio podem ser tomados como referência, para testes com outras madeiras e outras espessuras.

\section{c - Cálculo da densidade aparente pelo método convencional e nuclear}

Pelos resultados obtidos nos vários testes com radiação, pode-se concluir que os valores encontrados são compatíveis com aqueles obtidos pelo método convencional, apresentando diferenças muito pequenas, qualificando plenamente a técnica. É preciso refinar a técnica, com o uso de fontes com atividades mais elevadas, maior colimação e portanto dando ênfase maior à proteção radiológica.

\section{d - Meias espessuras}

Levando-se em conta os valores obtidos para os coeficientes de absorção, que se provaram corretos, por conseguinte os valores das meias-espessuras, salvo algum erro de cálculo, são perfeitamente aceitáveis, uma vez que o resultado para esses cálculos levou em consideração um parâmetro fixo $(0,69314=\ln 2)$ e os coeficientes de absorção linear (equação 4).

\section{e - Teste simulado em postes com ${ }^{137} \mathrm{Cs}$}

Pode-se concluir que o uso da técnica de detecção de vazios em postes está validada, haja vista a grande sensibilidade do ensaio, que permitiu a detecção de um vazio (falta de material) de 16,5 mm de espessura ou diâmetro, com diferença de contagens de 25 $\mathrm{c} / \mathrm{s}$, bem acima daquela imposta para limite $(10 \mathrm{c} / \mathrm{s})$. 
A FIG.22 permite-nos concluir, que na extrapolação da reta até a reta de $10 \mathrm{c} / \mathrm{s}$, pode-se ensaiar estruturas de ipê ou eucalipto citriodora a $12 \%$ de umidade até cerca de $630 \mathrm{~mm}$ de diâmetro.

Se for considerado esse limite de detecção em 5 c/s, o que é perfeitamente aceitável na técnica nuclear (cinco vezes o BG), esse valor de ensaio chega a 750mm de diâmetro..

Esse limite pode ser ultrapassado se for aumentado a atividade da fonte, fato perfeitamente possível, pois além da fonte ser produzida no CTR (Centro da Tecnologia das Radiações), o ponto focal da fonte radioativa se mantém. Os ensaios foram feitos com uma fonte de $228 \mu \mathrm{C}_{\mathrm{i}}\left(843,6 \times 10^{4} \mathrm{~Bq}\right)$, em 2012 , podendo chegar a 4 vezes esse valor, com um acréscimo pequeno na blindagem de chumbo e assim manter a proteção radiológica atual.

\section{f -Teste simulado em árvores $\operatorname{com}^{137} \mathrm{Cs}$}

Pode-se concluir que a sensibilidade da técnica é razoável, uma vez que permite detectar vazios entre $21,4 \mathrm{~mm}$ e $37,4 \mathrm{~mm}$ (de uma espessura total de $327 \mathrm{~mm}$ ), com contagens entre $8 \mathrm{c} / \mathrm{s}$ (pouco abaixo do limite estabelecido) e $15 \mathrm{c} / \mathrm{s}$ (50\% acima do limite) podendo ser ampliada com o aumento da atividade da fonte radioativa e uma colimação melhor. 


\section{TRABALHOS FUTUROS}

Laboratório

1. Refinar a técnica com ${ }^{137} \mathrm{Cs}$ :

1.1 Utilizando uma fonte com maior atividade;

1.2 Melhor colimação;

1.3 Melhor blindagem.

2 Fazer ensaios com outras madeiras:

2.1 Banco de dados com coeficientes de absorção linear;

2.2 Banco de dados com coeficientes de absorção de massa;

2.3 Banco de dados com meias espessuras;

2.4 Espessuras ótimas de ensaio.

3. Construir uma família de curvas em função da umidade e portanto da densidade, como as das FIG. 22 e 24, para as madeiras ipê, sucupira e eucalipto.

Campo

1. Testes com árvores vivas, próximas com extensão da fiação e distantes com bateria;

2. Adquirir um umidímetro, para medida "in loco", da umidade, em postes e árvores, para posterior conversão a $12 \%$ de umidade;

3. Construir um equipamento melhor para fixação em árvores. 


\section{ANEXOS}

ANEXO I

\section{ÁRVORES E MADEIRAS DE INTERESSE}

\section{Freijó (Cordia goeldiana )Huber}
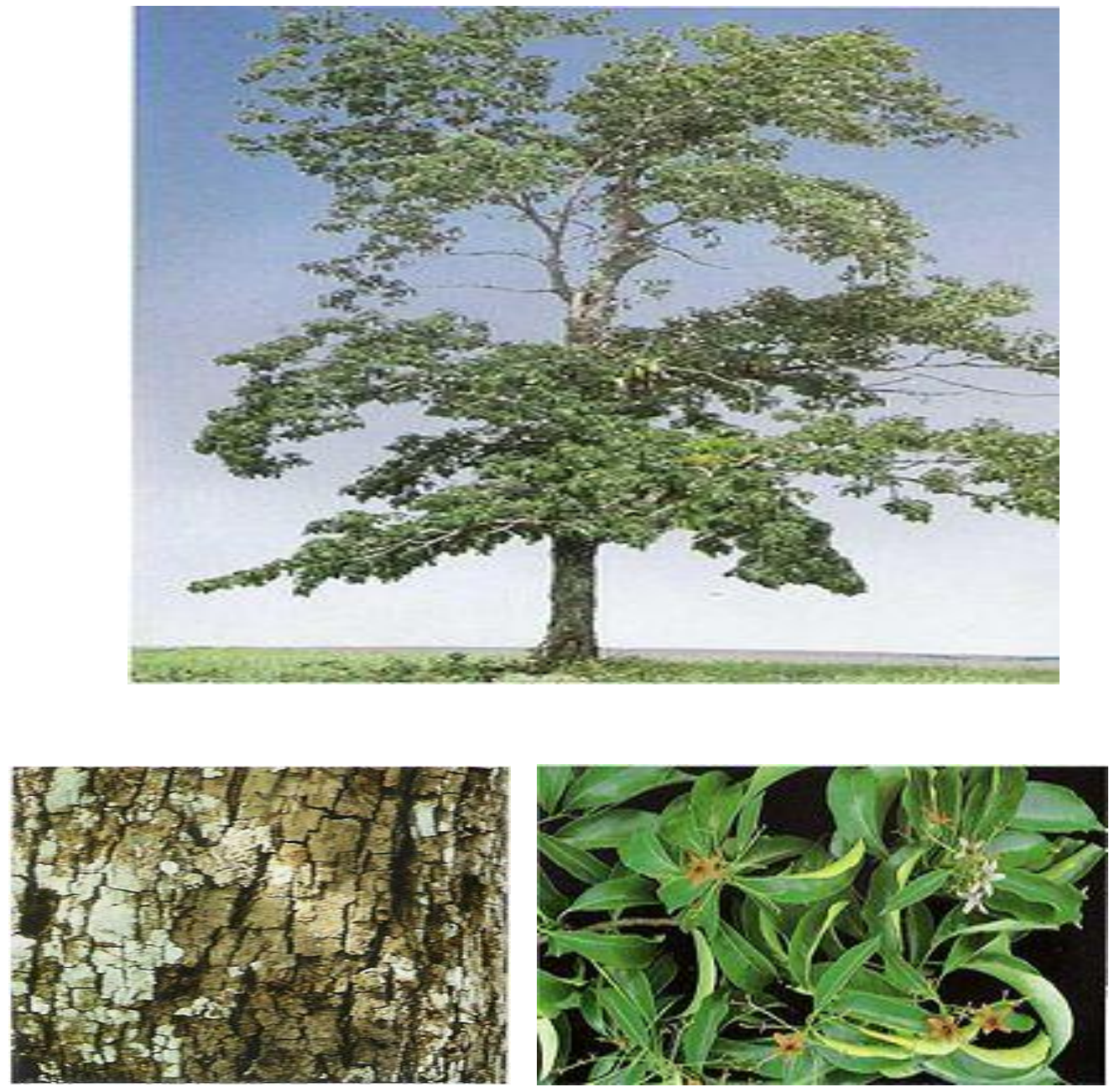

FIGURA 25 - Árvore, Folhas, flores e casca (Freijó)

Árvore da família Boraginaceae, atinge, de $10 \mathrm{~m}$ a $20 \mathrm{~m}$ de altura, com tronco de $40 \mathrm{~cm}$ a $60 \mathrm{~cm}$ de diâmetro. Folhas membranáceas, glabras, de $8 \mathrm{~cm}$ a $15 \mathrm{~cm}$ de comprimento por $4 \mathrm{~cm}$ a $8 \mathrm{~cm}$ de largura. Apresenta flores brancas, reunidas em panículas terminais curtas e tem características ornamentais, principalmente quando florida, podendo ser empregada no paisagismo em geral.

Outros nomes: frei-jorge, cordia-preta, freijó verdadeiro, louro-freijó, freijó rajado.

Ocorrência: Toda a região amazônica, especialmente estado do Pará, nas matas de terra firme, no baixo Amazonas. 
Madeira: madeira leve, em torno de $0,60 \mathrm{~g} / \mathrm{cm}^{3}$, densidade a verde de $0,95 \mathrm{~g} / \mathrm{cm}^{3}$, tem textura média, grã direita, superfície lustrosa, tendo moderada resistência ao ataque de organismos xilófagos.

Utilidade: confecção de móveis finos, folhas flaqueadas, decorativas, painéis, lambris, coronhas de armas, venezianas e persianas.

\section{Peroba-mica (Aspidosprma populifolium) A. DC.}
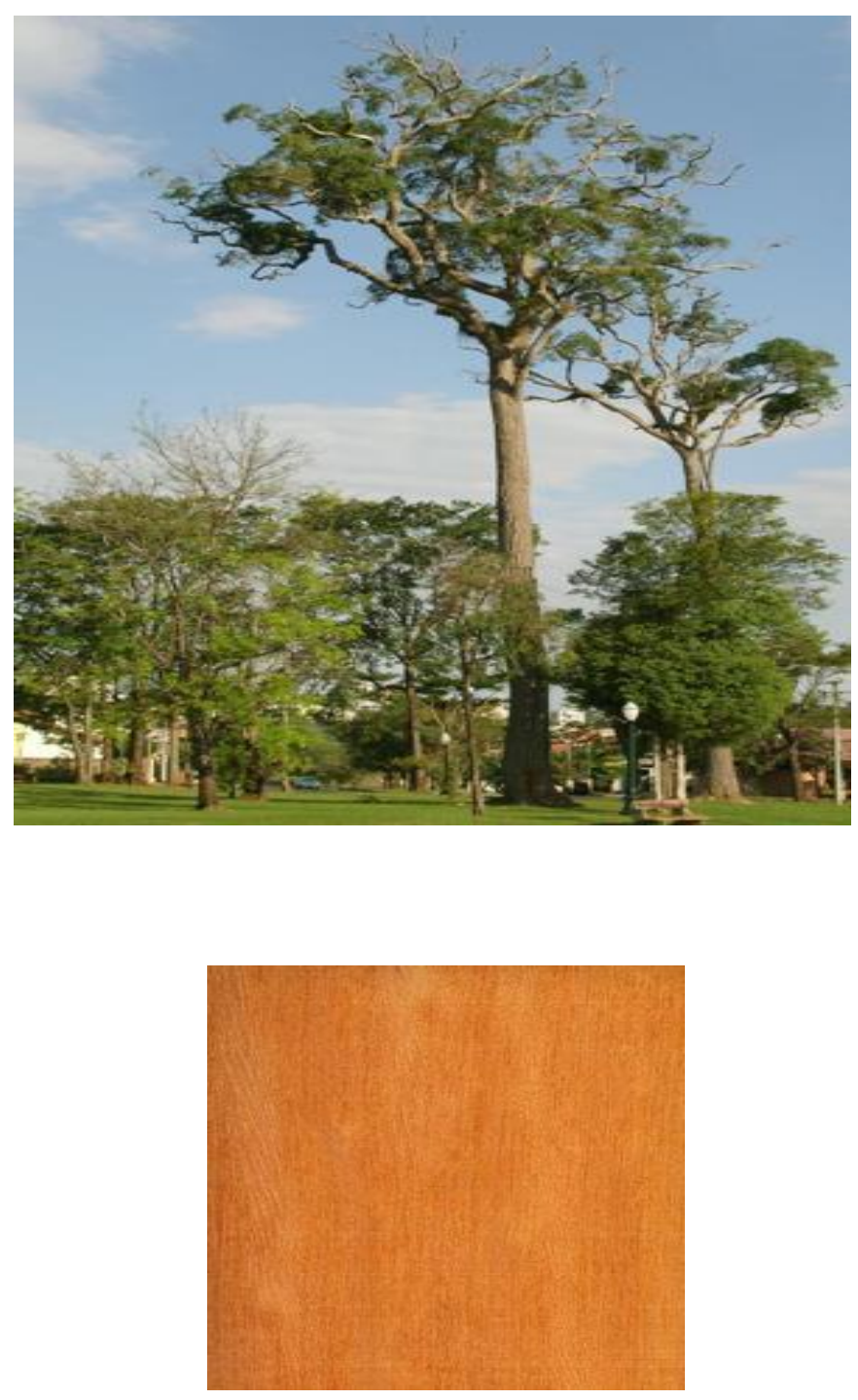

FIGURA 26 - Árvore e madeira (Peroba-mica)

Árvore da família Apocynaceae, alcança no máximo 30m de altura, podendo atingir $75 \mathrm{~cm}$ de diâmetro. Apresenta fuste alto e cilíndrico com a copa concentrada no ápice da árvore. A casca é profundamente fissurada e corticosa. A árvore é muito ornamental, principalmente pela copa piramidal, podendo ser usada no paisagismo em geral. 
Ocorrência: Estados do Amazonas, Pará, Rondônia e Mato Grosso.

Madeira: medianamente pesada, em torno de $0,70 \mathrm{~g} / \mathrm{cm}^{3}$, dura e muito compacta, possui superfície pouco lustrosa. É resistente ao apodrecimento quando não exposta a umidade, porém sensível ao ataque de cupins de madeira seca.

Utilidade: construção civil (vigas, caibros, batentes, rodapés, assoalhos), móveis, laminados, cabos de ferramentas.

\section{Jequitibá (Cariniana legalis) (Mart.) Kuntze}
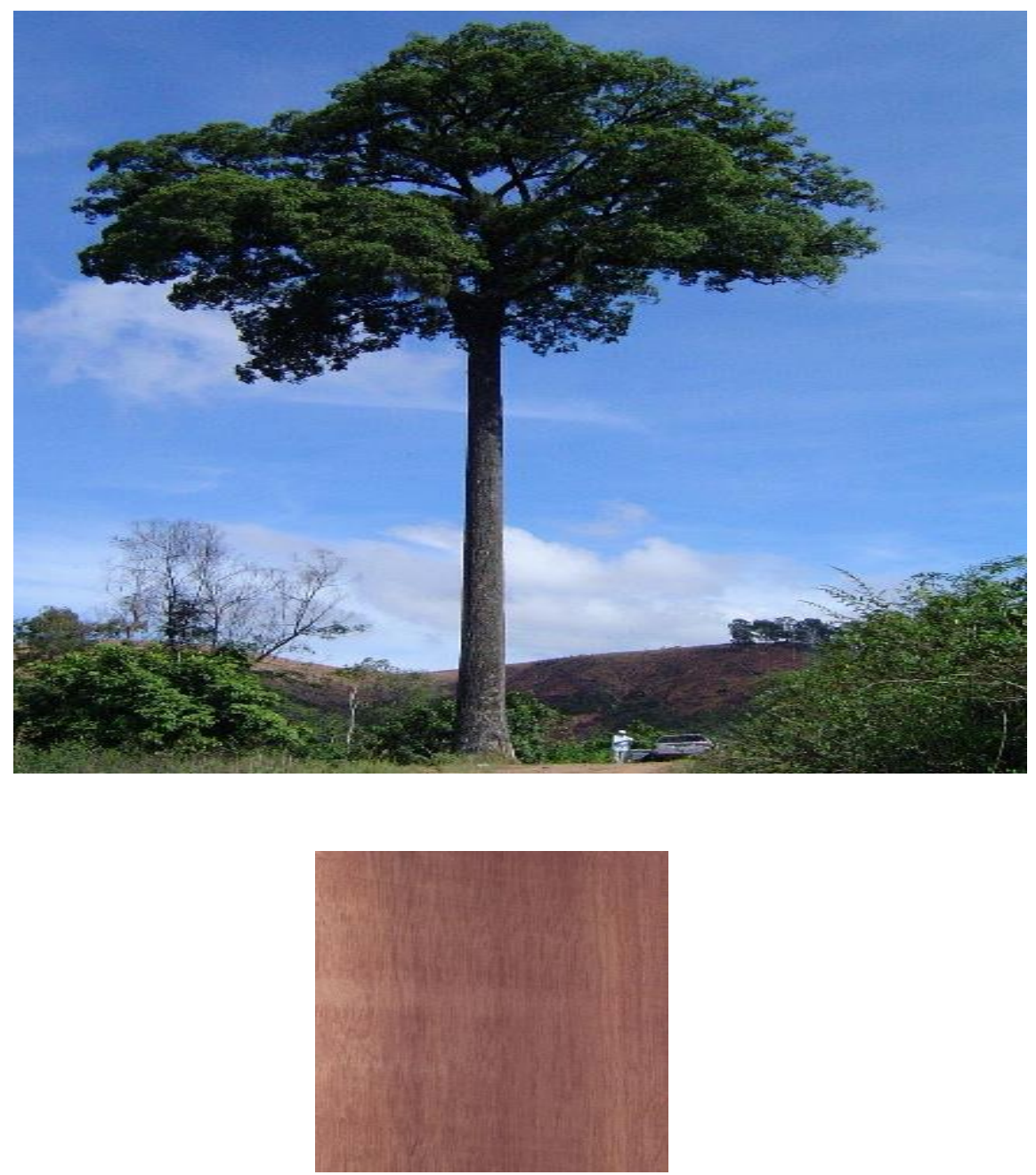

FIGURA 27 - Árvore e madeira (Jequitibá)

Árvore da família Lecythidaceae, de grande porte, chegando a atingir 50m de altura e tronco de $100 \mathrm{~cm}$ de diâmetro. Apresenta folhas membranáceas, glabras, de $4 \mathrm{~cm}$ a $7 \mathrm{~cm}$ de comprimento e $2 \mathrm{~cm}$ a $4 \mathrm{~cm}$ de largura. Apresenta flores de cor creme sendo uma das maiores árvores da flora brasileira, e sendo extremamente exuberantes e ornamentais, podem ser utilizadas em paisagismo em locais de grande espaço, como parques. 
Outros nomes: jequitibá-cedro, jequitibá-agulheiro, estopa, jequitibá grande, paucaixão, pau-carga.

Ocorrência: toda a Região Sudeste (Minas Gerais, São Paulo, Rio de Janeiro e Espirito Santo), Mato Grosso do Sul, tanto na floresta pluvial atlântica como na latifoliada semidecídua da bacia do Paraná.

Madeira: medianamente pesada, em torno de $0,75 \mathrm{~g} / \mathrm{cm}^{3}$, macia ao corte, grã direita, textura média e de baixa resistência ao ataque de organismos xilófagos, quando exposta a condições adversas.

Utilidade: própria para uso interno em construção civil, brinquedos, saltos de sapato, lápis.

\section{Muiracatiara (Astronium lecointei) Ducke}
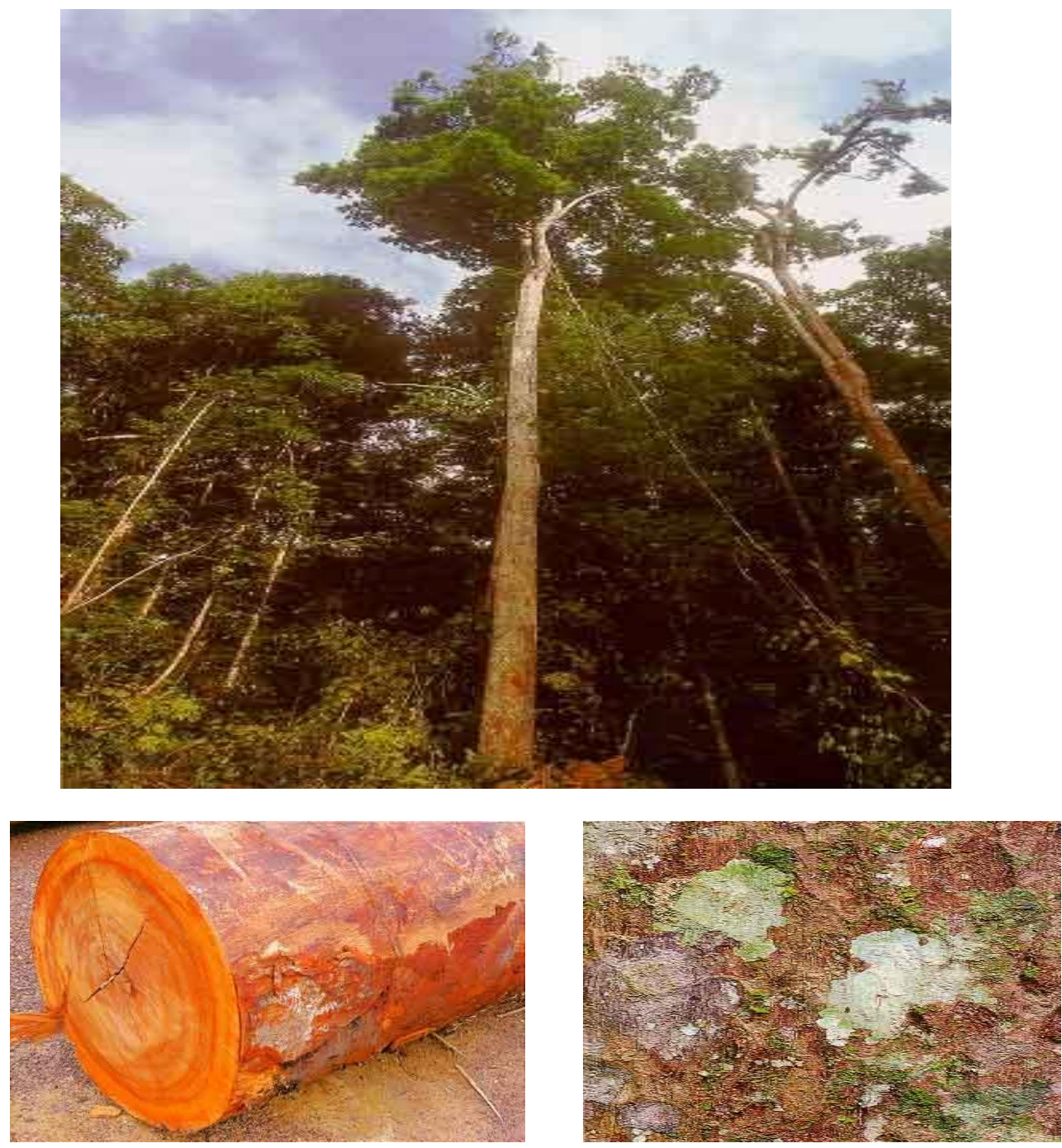

FIGURA 28 - Árvore, tronco e casca (Muiracatiara) 
Árvore da família Anacardiaceae, de grande porte, casca fissurada, exudando seiva aquosa. São árvores com flores hermafroditas e unissexuais, completamente sem folhas no fim da floração.

Outros nomes: maracatiara, baracatiara, muiraquatiara, gonçaleiro, aroeira, gonçalo-alves, sanguessugueira, muiracatiara-rajada, guarabu-rajado.

Ocorrência: habita as matas primárias da Região Norte, principalmente no Pará, Amazonas e Roraima.

Madeira: pesada, com densidade aparente variando entre $0,85 \mathrm{~g} / \mathrm{cm}^{3}$ a $0,90 \mathrm{~g} / \mathrm{cm}^{3}$ e densidade a verde em torno de $1,20 \mathrm{~g} / \mathrm{cm}^{3}$. Apresenta cerne marrom-rosado-pálido a marrom-amarelado e alburno mais claro. Tem grã ondulada e levemente revessa, textura média, brilho moderado, tendo grande resistência ao corte manual transversal.

Utilidade: usada na construção civil interna (assoalhos, lambris, marcos de portas e janelas, rodapés, escadas); em móveis finos, instrumentos musicais e cabos de ferramenta.

\section{Cumaru (Dipteryx odorata) (Aubl.) Willd.}
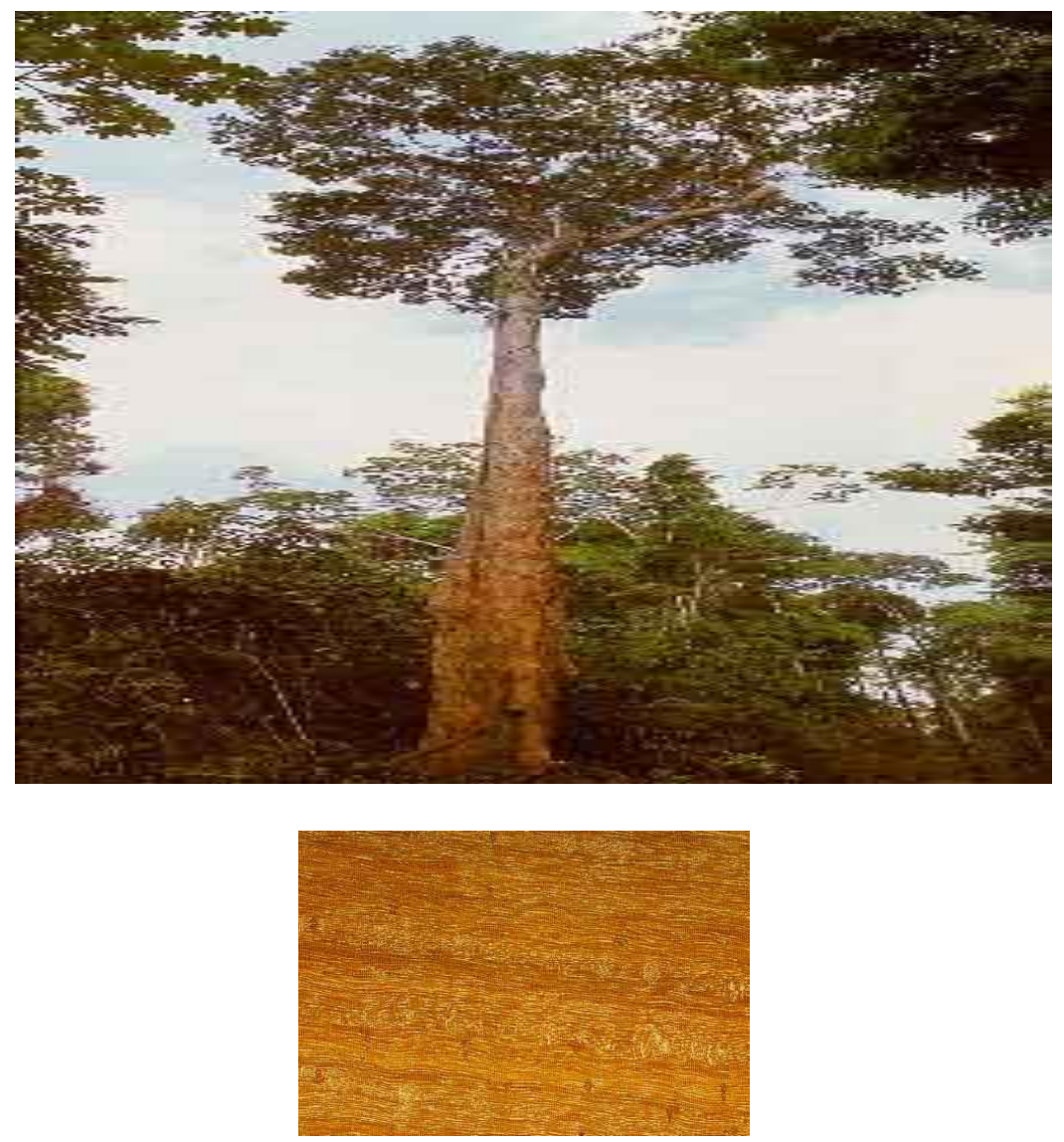

FIGURA 29 - Árvore e madeira (Cumaru) 
Da família Fabaceae, é arvore de grande porte, podendo atingir 30m de altura, casca lisa amarelada, fuste liso e cilíndrico, com presença de sapopemas, de diâmetro que alcança até $1 \mathrm{~m}$ de altura.

Outros nomes: Cumaru-amarelo, cumari, combari, cumbaru, cumaru-verdadeiro, baru, champagne, champanha.

Ocorrência: espécie de ampla distribuição, ocorre nas matas de terra firme e várzeas altas do baixo Amazonas, sendo frequente em toda a região amazônica, inclusive em países frontreiriços ao Brasil.

Madeira: muito pesada de $0,90 \mathrm{~g} / \mathrm{cm}^{3}$ a $0,95 \mathrm{~g} / \mathrm{cm}^{3}$, densidade a verde de 1,28 $\mathrm{g} / \mathrm{cm}^{3}$, dura, de textura fina a média, grã revessa, de resistência mecânica elevada e muito resistente ao ataque de cupins e fungos apodrecedores.

Utilidades: construção civil, para uso interno (vigas, caibros, tacos, assoalhos, batentes, portas, forros) e uso externo (portões, postes, cruzetas, dormentes).

\section{Ipê (Tabebuia serratifolia) (Vahl) Nichols}

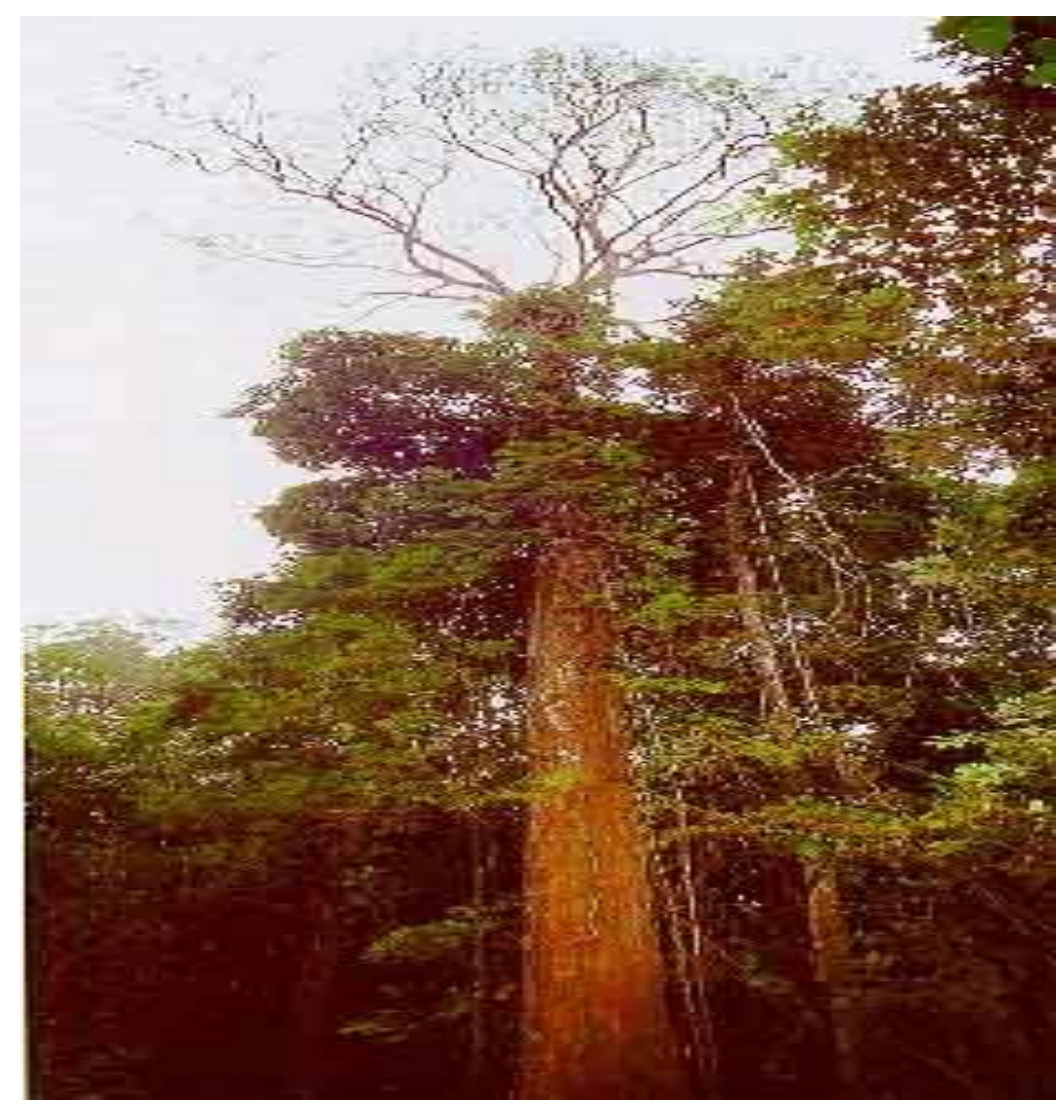



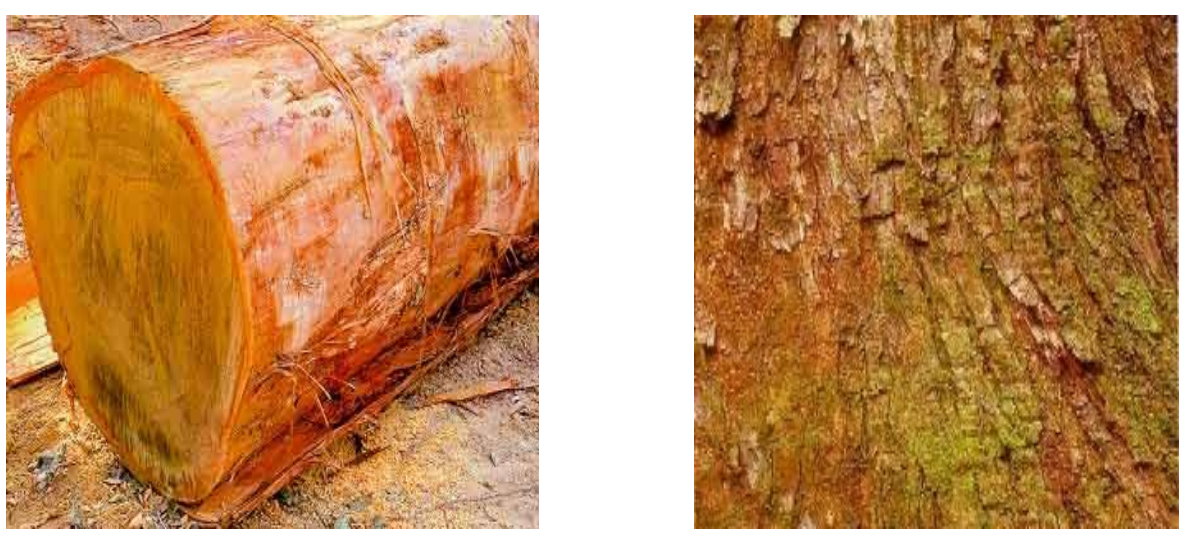

FIGURA 30 - Árvore, tronco e casca (Ipê)

Árvore da família Bignonaceae, de porte mediano, podendo atingir até $25 \mathrm{~m}$ de altura e tronco com $50 \mathrm{~cm}$ de diâmetro, com fuste reto e cilíndrico É uma árvore decídua, apresentando folhas compostas e palmadas, com folíolos, que caem no inverno, dando origem à floração. É uma ótima árvore para arborização urbana e não possui raízes agressivas.

Outros nomes: pau d'arco, ipê-do-campo, ipê-do-cerrado, ipê-tabaco, piúna, ipeúva, peúva, morototó.

Ocorrência: Distribui-se pela floresta amazônica e presente no Nordeste até o estado de São Paulo, no interior de floresta densa e primária e também em formações abertas e secundárias.

Madeira: seu tronco é elegante e oferece madeira de excelente qualidade, pesada, com densidade aparente em torno de $1,00 \mathrm{~g} / \mathrm{cm}^{3}$, densidade a verde de $1,24 \mathrm{~g} / \mathrm{cm}^{3}$, dura, de cerne acastanhado.

Utilidades: Madeira dura e resistente, própria para construções pesadas e estruturas externas, tanto civis como navais, como quilhas de embarcações, pontes, dormentes cruzetas, postes. 


\section{Sucupira (Bowdichia nítida) Spruce ex Benth}
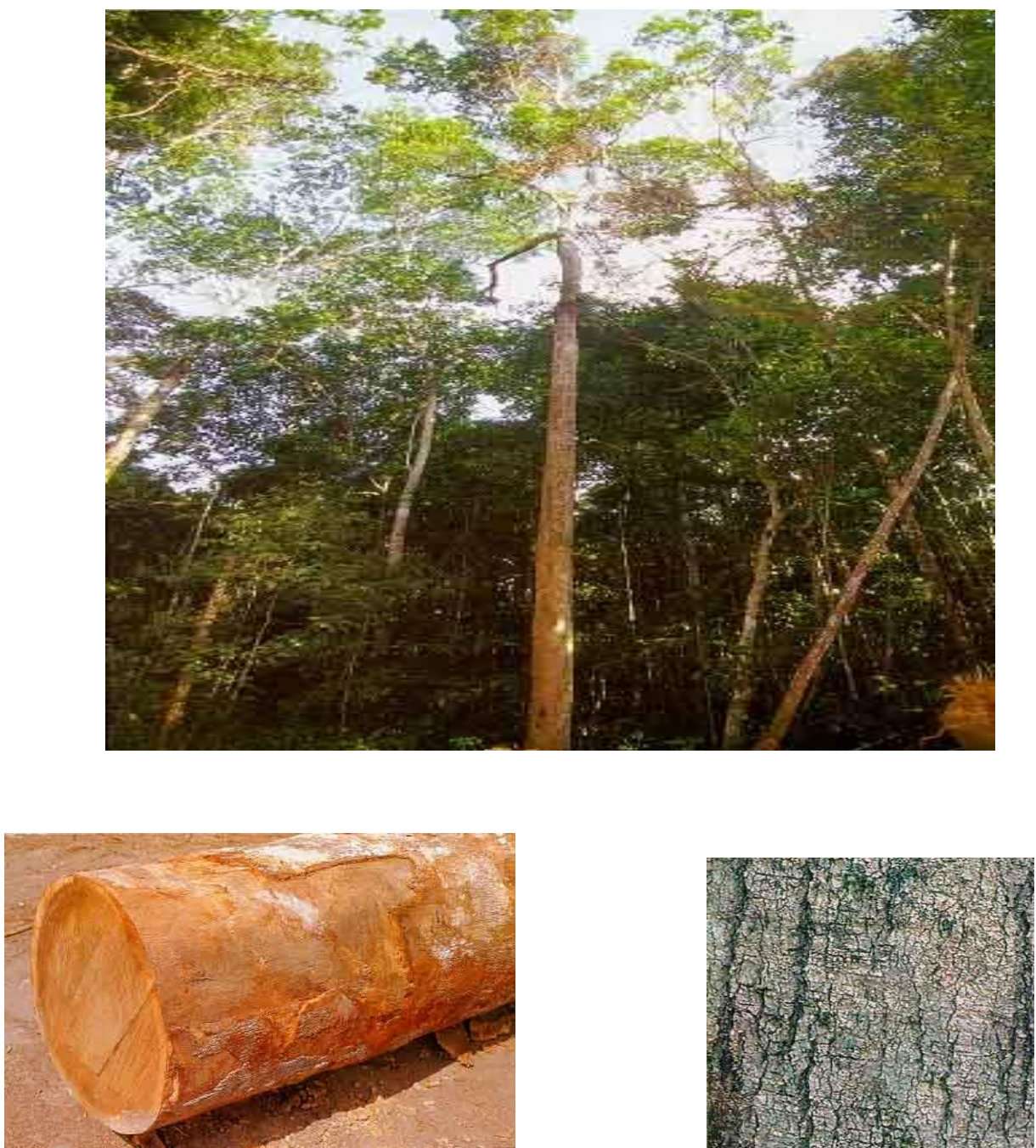

FIGURA 31 - Árvore, tronco e casca (Sucupira)

Árvore da família Fabaceae, apresenta altura mediana, em torno de $15 \mathrm{~m}$ de altura, com tronco de até $60 \mathrm{~cm}$ de diâmetro. Folhas compostas pinadas com 9 a 21 folíolos pubescentes. Flores violeta, dispostas em panículas terminais. É uma árvore decídua, heliófita, sendo ótima para o paisagismo em geral e no reflorestamento heterogêneo em áreas degradadas.

Outros nomes: cutiúba, macanaiba, macanaiba-pele-de-sapo, sapupira, sucupiraaçu, sucupira-parda.

Ocorrência: Mata Atlântica, incluindo Bahia, Espirito Santo, Minas Gerais e floresta amazônica, no Acre, Amazonas, Amapá, Rondônia. Apresenta ampla dispersão por todo o cerrado, porém com baixa densidade populacional. 
Madeira: extremamente pesada, podendo atingir densidades ao redor de $1,10 \mathrm{~g} / \mathrm{cm}^{3}$ (densidade aparente) e densidade a verde de $1,22 \mathrm{~g} / \mathrm{cm}^{3}$. Fibrosa, bastante decorativa e longa durabilidade natural.

Utilidade: empregada em acabamento interno (lambris, portas, assoalhos, molduras, rodapés, escadas, painéis), e externamente em pontes, postes e cruzetas. 
ANEXO II

\section{FONTES RADIOISOTÓPICAS USADAS}

\section{Características}

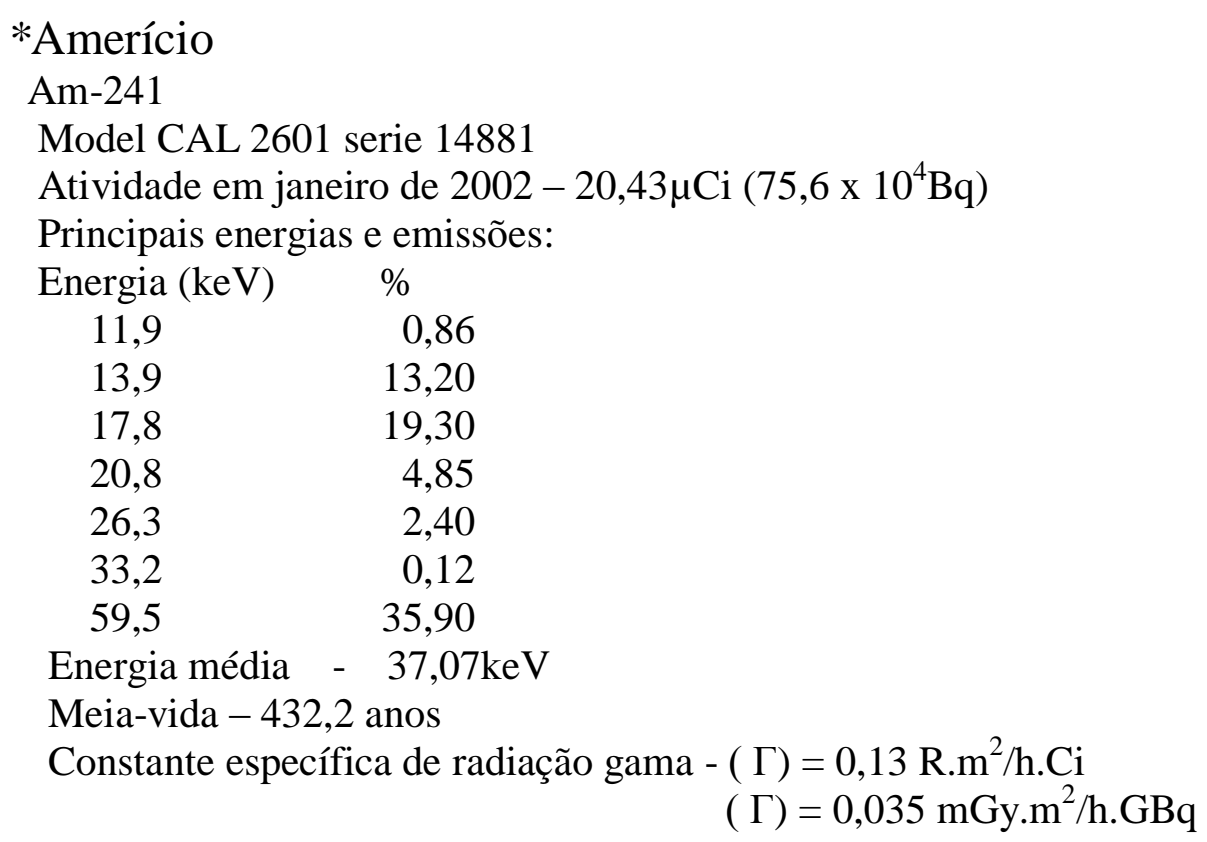

\section{*Bário}

Ba-133

Model CAL 2601 serie 14761

Atividade em janeiro de $2002-20,14 \mu \mathrm{Ci}\left(74,5 \times 10^{4} \mathrm{~Bq}\right)$

Principais energias e emissões:

\begin{tabular}{cr} 
Energia $(\mathrm{keV})$ & \multicolumn{1}{c}{$\%$} \\
30,6 & 34,40 \\
31,0 & 63,50 \\
35,0 & 18,80 \\
35,8 & 4,24 \\
53,2 & 2,20 \\
81,0 & 32,80 \\
160,6 & 0,72 \\
223,1 & 0,47 \\
276,4 & 7,29 \\
302,9 & 18,60 \\
356,0 & 62,30 \\
383,9 & 8,84
\end{tabular}

Energia média - $157,56 \mathrm{keV}$

Meia-vida - 10,54 anos

Constante específica de radiação gama $-(\Gamma)=0,44 \mathrm{R} \cdot \mathrm{m}^{2} / \mathrm{h} \cdot \mathrm{Ci}$

$$
\text { ( } \Gamma)=0,119 \mathrm{mGy} \cdot \mathrm{m}^{2} / \mathrm{h} \cdot \mathrm{GBq}
$$




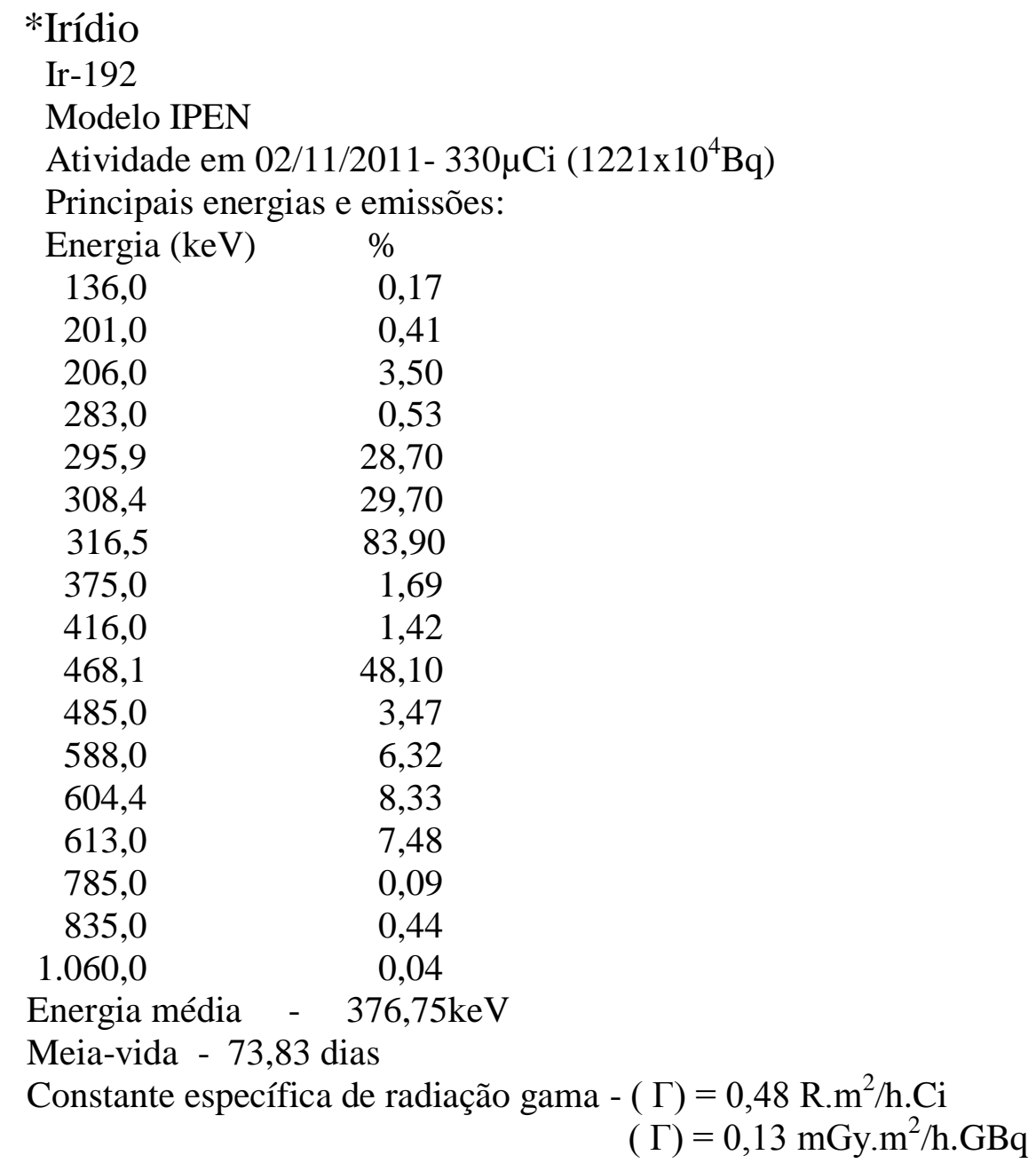

\section{*Césio}

Cs-137

Model CAL 2601 serie 4755

Atividade em 07/04/2012 - $22 \mu \mathrm{Ci}\left(843,6 \times 10^{4} \mathrm{~Bq}\right)$

Principais energias e emissões:

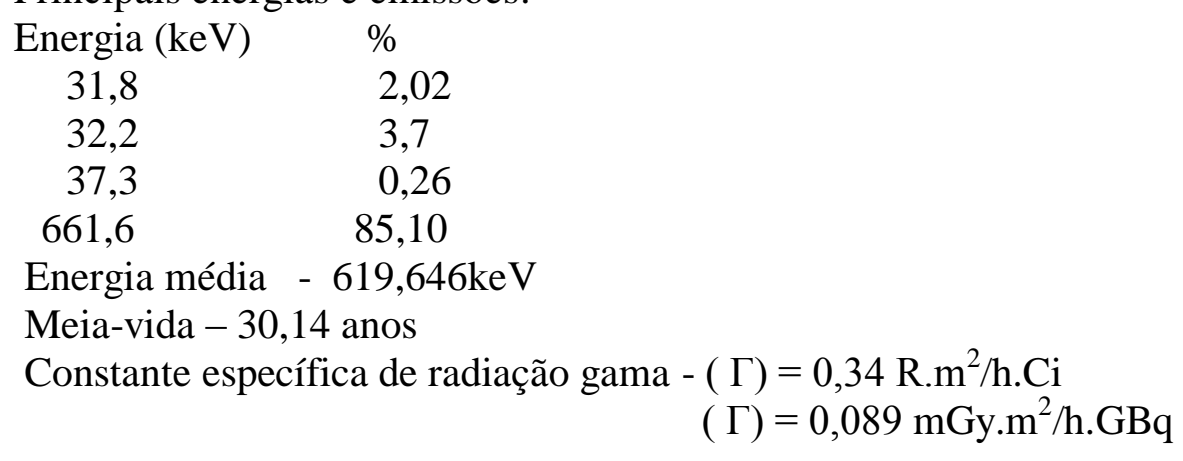


*Cobalto

Co-60

Model CAL 2601 serie 14757

Atividade em janeiro de $2002-20,81 \mu \mathrm{Ci}\left(76,9 \times 10^{4} \mathrm{TBq}\right)$

Principais energias e emissões:

Energia $(\mathrm{keV}) \quad \%$

346,9 $\quad 0,0076$

$1.173,2 \quad 99,90$

$1.332,5 \quad 100,00$

Energia média - $1.252,855 \mathrm{keV}$

Meia-vida - 5,29 anos

Constante específica de radiação gama $-(\Gamma)=1,30 \mathrm{R} \cdot \mathrm{m}^{2} / \mathrm{h} . \mathrm{Ci}$

( $\Gamma)=0,36 \mathrm{mGy} \cdot \mathrm{m}^{2} / \mathrm{h} \cdot \mathrm{GBq}$ 


\section{ANEXO III}

\section{GLOSSÁRIO DE ÁRVORES E MADEIRAS}

Água Livre: água contida nas cavidades celulares e intercelulares das madeiras. Ao iniciar o processo de secagem, a água livre é a primeira a ser retirada, estando completamente eliminada quando a madeira atinge o seu ponto de saturação das fibras.

Água Presa: Água que se encontra retida nas paredes das células e que começa a ser eliminada a partir da secagem abaixo do ponto de saturação das fibras, quando a madeira já perdeu toda a água livre. À medida que a madeira perde água presa, começam a ocorrer alterações.

Alburno: O mesmo que o branco da madeira, brancal ou borne. Parte situada entre a casca e o cerne, geralmente de coloração mais clara que este. É a parte do tronco que estava viva (transportava seiva) enquanto a árvore ainda estava de pé.

Alternas: Relativo à inserção das folhas nos ramos de maneira isolada e não aos pares.

Anel de Crescimento: Cada uma das camadas de crescimento da árvore.

Angiosperma: Grupo de plantas superiores que possuem sementes contidas em frutos verdadeiros, desenvolvidos a partir de óvulos contidos no ovário da flor.

Apical: Relativo ao ápice.

Arilo: Excrescência da semente, geralmente de textura suculenta.

Arqueamento: Empenamento longitudinal das bordas; curvatura ao longo do comprimento da peça de madeira, num plano paralelo à face.

Aspecto Fibroso: É o contraste observado nas superfícies das secções longitudinais de certas madeiras, intercalado entre a massa do tecido fibroso e do parenquimatoso.

Assimétrico: Sem simetria.

Bipenada: Se refere à uma folha composta duplamente pinada ou dividida, ou as divisões primárias são também divididas.

Câmbio: Camada de tecido meristemático que dá origem ao xilema e floema na estrutura secundária.

Celulose: Polissacarídeo estrutural das plantas.

Cerne: Parte interna do tronco da árvore, envolvida pelo alburno, geralmente caracterizada por colocação mais escura do que este. É a parte do tronco que já estava morta mesmo com a árvore ainda em pé. 
Composta: Diz-se da folha cuja lâmina (Limbo) é formada por dois ou mais folíolos que podem, por sua vez, subdividir-se.

Conífera: Árvores do grupo das Gimnospermas, cujas folhas tem formato de agulha ou escamas.

Conteúdo de Umidade: Quantidade de água contida na madeira, normalmente expressa em porcentagem do peso.

Decídua: Planta que perde todas as flores. durante um período do ano, geralmente durante o inverno ou durante a seca ou estiagem.

Dicotiledônea: Da classe das Angiospermas, é caracterizada pelo embrião provido de dois cotilédones. Apresenta raiz axial e estrutura secundária.

Eixo Longitudinal do Tronco: O mesmo que sentido axial ou longitudinal.

Elemento Vascular ou Segmento Vascular: Um dos componentes celulares.

Fibra: Elementos celulares longos, fusiformes e de paredes relativamente grossas, formando em conjunto o tecido fibroso responsável pela maior ou menor resistência da madeira. Individualmente não são visíveis sob lente de 10 aumentos.

Grã: Refere-se ao alinhamento geral das células da madeira com relação ao eixo principal da peça de madeira, podendo ser: direita, revessa ou ondulada.

Grã-direita: O fendilhamento provocado ao longo do plano radial ocorre facilmente e a superfície seccionada apresenta-se no mesmo plano de corte e paralela ao eixo longitudinal.

Grã-oblíqua: O fendilhamento provocado ao longo do plano radial ocorre facilmente e a superfície seccionada apresenta uma inclinação em relação ao plano de corte inicial.

Grã-revessa: O fendilhamento provocado ao longo do plano radial não ocorre facilmente devido ao intenso entrelaçamento das fibras apresentando uma superfície irregular e com muitas farpas.

Hemicelulose: É um polissacarídeo, que junto com a celulose, pectina e glicoproteínas, formam a parede celular das células vegetais.

Latifoleada: De folhas largas.

Lenho: Segmento qualquer do tronco ou raiz, constituído de tecidos responsáveis pela sustentação e condução da água e sais minerais.

Líber: Principal tecido de condução das substâncias nutritivas nas plantas vasculares (parte interna da casca). 
Linhas Vasculares: Pequenos canais ou cavidades alongadas que aparecem como linhas interrompidas, mais ou menos paralelas, na superfície longitudinal de algumas madeiras, resultante do corte longitudinal dos vasos.

Lignina: É uma macromolécula tridimensional, amorfa, encontrada nas plantas terrestres, associada à celulose na parede celular e cuja função é conferir aos tecidos vegetais, rigidez, impermeabilidade e resistência, mecânica e a ataques biológico.

Lúmen: Cavidade de cada elemento celular.

Oposta: Diz-se das folhas que se inserem aos pares no mesmo nível do caule.

Organismos Xilófagos: Organismos que atacam madeira.

Parênquima: Tecido constituído por células de armazenamento nas plantas, normalmente mais claro que a parte fibrosa da madeira por ser de células curtas, iguais e de paredes finas. Classifica-se em parênquima axial ou longitudinal e parênquima radial.

Poro: Denominação usual para designar a abertura dos vasos vistos na seção transversal da madeira.

Raios Estratificados: Quando se dispõem regularmente tangencialmente à superfície, arrumados de modo a formarem séries paralelas que se distribuem como em andares.

Raios Lenhosos: Agregados de células parenquimatosas arrumadas no sentido radial em relação ao eixo da árvore. Na superfície de topo aparecem como numerosas linhas retilíneas aproximadas, geralmente mais claras; na tangencial toma geralmente a forma lenticular.

Raios Não Estratificados: Quando se dispõem na superfície tangencial de modo irregular.

Sapopemas: Raízes laterais, de forma tabular, que cercam a base do tronco de algumas árvores.

Seção radial: Plano de corte da madeira, paralelo aos raios lenhosos, normalmente em ângulo reto com as camadas de crescimento.

Seção Tangencial: Plano de corte da madeira no sentido axial e em ângulo reto com os raios lenhosos.

Seção Transversal: Plano de corte da madeira perpendicular às fibras.

Teor de Umidade de Equilíbrio: É o teor de umidade onde a madeira nem ganha e nem perde água em determinadas condições de umidade relativa do ar e temperatura.

Traqueídeos: Um dos tipos de células condutoras do tecido xilemico. São responsáveis pela condução de água e solutos.

Vasos: Estrutura tubular formada pela união de grandes células em uma coluna longitudinal, cuja principal função é o transporte de seiva. 


\section{REFERÊNCIAS BIBLIOGRÁFICAS}

ABREU, L.B. de. Ensaios Não-Destrutivos para Avaliação da Integridade de Elementos Estruturais em Construções Históricas, 2010. Tese (Doutorado). Universidade Federal de Lavras, Lavras.

ARRUDA, R.P.; DEDAVID, B.A; PIRES, M; VIDOR, F.L.R.. Estudo sobre caracterização de postes de madeira utilizados em linhas de transmissão de energia através de ensaios de flexão e compressão. In: Congresso Brasileiro de Engenharia e Ciência dos Materiais, Foz do Iguaçu, 2006. Anais... 17 CBECiMat, 2006.

AMERICAN SOCIETY FOR TESTING AND MATERIALS. Industrial radiographic films. ASTM, 1984 (ASTM E 94)

ARAÚJO, H.J.B. de, Relações Funcionais entre Propriedades Físicas e Mecânicas das Madeiras Tropicais Brasileiras. Floresta, v.37, n.3, 2007.

ASSOCIAÇÃO BRASILEIRA DE NORMAS TÉCNICAS. Projeto de estruturas de madeiras . Rio de Janeiro, ABNT, 1997 (NBR 7190).

BESLEY, L. Importance, variation and measurement of wood density and moisture. Pulp and Paper Research Institute of Canada, n. 489, p. 1-30, 1966.

BROCHARD, F.X. Bois et charpente en bois. Éditions Eyrolles, 1960.

BUCUR, V. Techniques for high resolution imaging of wood structure: a review. Measurement Science and Technology, 14, 2003.

CARVALHO, A. Madeiras Portuguesas-Instituto Florestal, v. I, 415 p. , Lisboa, 1996.

CISTERNAS, P.A. Conversión de densidades de la madera. Ciencia y Investigación Forestal, v. 8, n. 2, p. 300-315, 1994.

DIAS, F.M.; LAHR, F.A.R. Estimativa das propriedades de resistência e rigidez da madeira através da densidade aparente. Scientia Forestalis, n. 65, p. 102-113, 2004.

FERREIRA, M. Estudo da variação da densidade básica da madeira de Eucaliptus alba REIW e Eucaliptus saligna SMITH. IPEF, n. 1, p. 83-96, 1970.

GALVÃO, A.P.M. Estimativas de umidade de equilíbrio da madeira em diferentes cidades do Brasil. IPEF, n. 11, p. 63-65, 1975.

HELLMEISTER, J.C. Madeiras e suas características. In: $1^{\circ}$ Encontro Brasileiro de Estruturas de Madeira, 1983, São Carlos. Anais... São Carlos, 1983, v.1.

INSTITUTO BRASILEIRO DO MEIO AMBIENTE - Laboratório de Pesquisa FlorestalBanco de Dados de Madeiras Brasileiras-IBAMA, Brasília, 2005.

INTERNATIONAL STANDADRD ORGANISATION. Sealed radioactive source classification. ISO, 1980. (ISO 2919). 
KLOCK, U. Química da madeira. Curso de Engenharia Industrial Madeireira. Universidade Federal do Paraná, 2007.

KODAK, E. (Ed). Radiograph in modern industry. New York, Rochester, 1969.

KOLLMANN, F.E.P.; CÔTÉ, W.A. Principles of wood science and technology. Springer-Verlag, v. 1, 1969.

LORENZI, H. Árvores Brasileiras. Manual de identificação de plantas arbóreas nativas do Brasil. v. 1 e 2, $4^{\mathrm{a}}$ e $2^{\mathrm{a}}$ ed. Instituto Plantarum, 2002.

SANCHEZ, W. Ensaios não destrutivos pela técnica dos raios-X e raios gama. Informação IEA, n. 29, 1974.

SHIMOYAMA, V.R.; BARRICHELO, L.E.G. Influência das características anatômicas e químicas sobre a densidade básica da madeira de eucalyptus spp. In: Congresso Anual de Celulose e Papel, 24, São Paulo, 1991. Anais... São Paulo: ABCCP, 1991.

SIMPSON, W.T. Equilibrium moisture content prediction for wood. Forest Products Journal, v. 21, n. 2, p. 48-49, 1971. 